

Universidade de Brasília

Faculdade de Comunicação - FAC

Departamento de Comunicação Social

Projeto final em Comunicação Organizacional

Orientadora: Profa. Dra. Ellis Regina Araújo da Silva

Identidades do jornalismo cidadão:

uma análise da cultura organizacional da Mídia Ninja

Fernanda Vieira Bastos

Brasília

2018 
FERNANDA VIEIRA BASTOS

Identidades do jornalismo cidadão:

uma análise da cultura organizacional da Mídia Ninja

\begin{abstract}
Monografia apresentada ao Curso de Comunicação Organizacional da Faculdade de Comunicação da Universidade de Brasília, como requisito parcial para a obtenção do grau de Bacharel em Comunicação Social com habilitação em Comunicação Organizacional.
\end{abstract}

Orientadora: Profa. Dra. Ellis Regina Araújo da Silva

Brasília 


\title{
Identidades do jornalismo cidadão: uma análise da cultura organizacional da Mídia Ninja
}

\begin{abstract}
Monografia apresentada ao Curso de Comunicação Organizacional da Faculdade de Comunicação da Universidade de Brasília, como requisito parcial para a obtenção do grau de Bacharel em Comunicação Social com habilitação em Comunicação Organizacional.
\end{abstract}

Orientadora: Profa. Dra. Ellis Regina Araújo da Silva

\section{BANCA EXAMINADORA}

Prof. Dr. Ellis Regina Araújo da Silva

Orientadora

Prof. Dr. Márcia Marques

Rosa Helena Santos

Prof. Dr. João José Curvello

Suplente

Brasília

2018 
Dedico este trabalho a todos que buscam a democratização da comunicação e lutam por um mundo melhor. 


\section{AGRADECIMENTOS}

O meu grande agradecimento às três pessoas que sem as quais eu não seria nada. A minha família, que me incentivou, me escutou, me apoiou e me amou desde o meu nascimento. Ao meu pai, Geraldino, meu grande herói, um grande intelectual e exemplo de superação, meu muito obrigada, por ter me guiado na escolha do meu curso e em muitas outras decisões da minha vida, obrigada por ser meu farol. A minha mãe, Maria Imaculada, que com seu jeito arte de viver, me ensinou a ter a leveza para enfrentar os dias menos bons e me deu seu abraço apertado para comemorar todas as minhas vitórias, obrigada por ser meu riso certo sempre. A minha querida irmã, Isabela, que desde pequena me defende do mundo e que me aconselha da melhor forma possível. Vocês são meu tudo, meu muito obrigada.

Aos meus amigos, tão queridos, que me escutaram em todos os momentos de tristeza e desespero do meu TCC e que estiveram sempre lá para comemorar por mim quando um capítulo era entregue para a orientadora. Obrigada por me tirarem durante um tempo do universo do Trabalho de Conclusão de Curso e me fazerem esquecer dele por algumas boas horas repletas de risadas. As minhas irmãs de alma, Karoline, Letícia Lucena, Amanda, Laura, Letícia Corrêa e Cláudia, aos meus maravilhosos amigos da escola entre eles, Iure, Marina e Clarissa, aos meus queridos amigos do curso da UFRJ e da UnB, entre eles, meu amado trio Brenda, Ygor e Rebeca - que fizeram os quatro anos de graduação serem inesquecíveis, as minhas primas-irmãs, entre elas, Illa e Lud e aos meus primos, meu muito obrigada por me apoiarem durante toda a trajetória acadêmica e durante a vida.

A minha querida orientadora, professora Ellis Regina, que sempre me elogiou e me colocou lá em cima. Afirmo que hoje só consegui concluir este presente trabalho com os conselhos, dicas e os empurrões que ela me deu para me encorajar. Um muito obrigada também aos meus outros professores, da UnB e da UFRJ - onde realizei um semestre de mobilidade estudantil - que me ajudaram e me inspiraram durante todo o curso e me presentearam com lições e ensinamentos que levarei para a vida. Um agradecimento especial aos servidores e funcionários da universidade tão queridos e presentes durante toda a graduação. Universidades são inspiração e precisam do nosso cuidado. Obrigada UnB, por ter me transformado em tantos aspectos e vida longa ao ensino público de qualidade. 
"Todo dia, o sol levanta e a gente canta ao sol de todo dia."

Caetano Veloso 


\section{RESUMO}

O jornalismo cidadão é uma das principais formas de democratizar a comunicação. A pesquisa possui o objetivo de compreender a cultura organizacional de uma das grandes representantes desse tipo de jornalismo, a Mídia Ninja. Para isso, utilizou-se a metodologia triangular com a aplicação de questionários, realização de entrevistas e a observação participante nas sedes da Mídia Ninja Brasília e Mídia Ninja Belo Horizonte. O trabalho orientou-se pelo marco teórico das áreas de Jornalismo e Comunicação Organizacional e alcançou resultados que caracterizam o objeto de estudo: a colaboração como valor intrínseco da organização, a utilização das tecnologias para a comunicação interna, a mutação constante das equipes regionais, a solidariedade como moeda social e o modelo de funcionamento horizontal.

Palavras-chave: Comunicação Organizacional, Cultura organizacional, Jornalismo cidadão, Mídia Ninja, Jornalismo Independente. 


\section{LISTA DE ILUSTRAÇÕES}

IMAGEM 1 - Pirâmide de Maslow .41

IMAGEM 2 - Clayton Lopes, jornalista da Mídia Ninja no ambiente de trabalho, escritório do coletivo RUAS .47

IMAGEM 3 - Reunião realizada para alinhamento da equipe do ATL

IMAGEM 4 - marcha indígena em direção ao Congresso Nacional realizada no ATL 2018..50

IMAGEM 5 - Marcha da Conape no centro de Belo Horizonte .52

IMAGEM 6: Resumo das atividades da pesquisa de campo. .53

IMAGEM 7: Escritório do RUAS, ambiente de trabalho da Mídia Ninja Brasília. .56

IMAGEM 8: Reunião de povos indígenas na tenda principal do Acampamento Terra Livre..57

IMAGEM 9: Sala da casa Mídia Ninja Minas localizada em Belo Horizonte. .58

IMAGEM 10: Thanee Degasperi trabalhando no escritório da casa Mídia Ninja Minas. .59

IMAGEM 11: esquema de organização das palavras relacionadas a Mídia Ninja pelos respondentes do questionário.

IMAGEM 12: respostas da questão sobre eficiência da comunicação interna da Mídia Ninja. . .64

IMAGEM 13: respostas sobre características da comunicação entre os membros. .66

IMAGEM 14: respostas sobre características da comunicação entre os membros e líderes...67

IMAGEM 15: respostas sobre feedbacks realizados entre membros. .71

IMAGEM 16: respostas sobre feedbacks realizados entre líderes e membros. . .72

IMAGEM 17: respostas sobre motivos de felicidade dentro da empresa 74 


\section{SUMÁRIO}

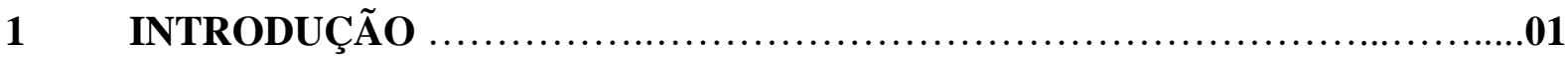



2.1 A rede Fora do Eixo e a PósTV ....................................................

2.2 Origem da Mídia Ninja e as "Jornadas de junho" ..........................................................7

2.3 Cinco anos de desafios, polêmicas e crescimento.............................14

3 DA IMPRENSA DA INDEPENDÊNCIA A ERA DA CONVERGÊNCIA

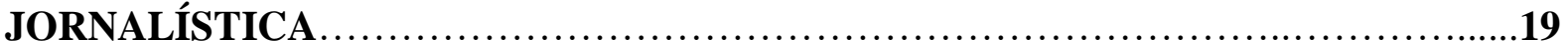

3.1 Contextualização histórica do jornalismo brasileiro..............................19

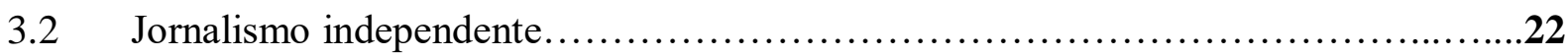

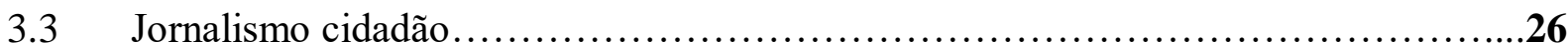

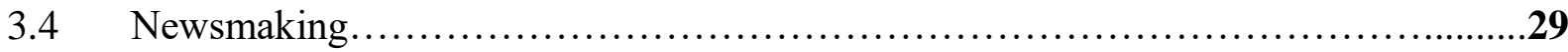

4 A COMUNICAÇÃO ORGANIZACIONAL DO JORNALISMO NÃO

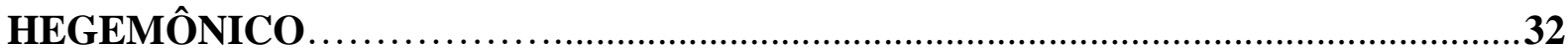

4.1 Cultura, clima e identidade organizacional: conceitos, definições e conexões.............32

4.2 O jornalismo da era do audiovisual..........................................

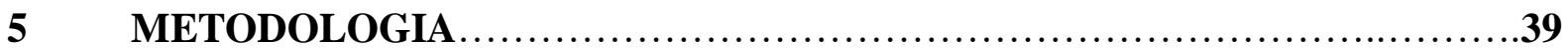

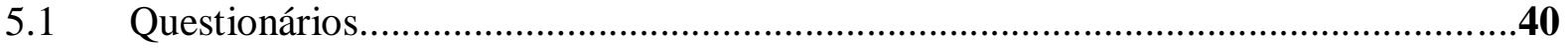

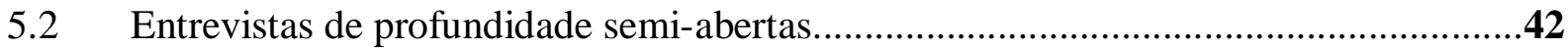



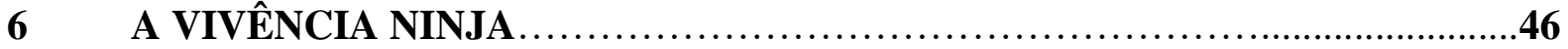

6.1 Descrição da aplicação da pesquisa.............................................................................6

6.2 Análise do público interno da Mídia Ninja..............................................................53

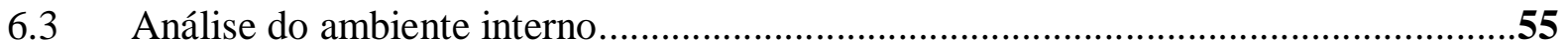

6.4 A cultura organizacional da Mídia Ninja..................................................................59

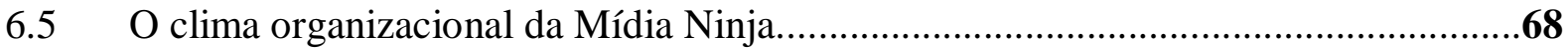

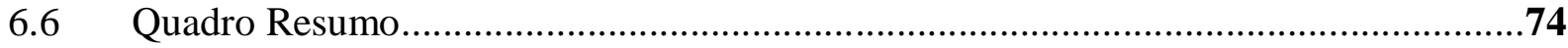

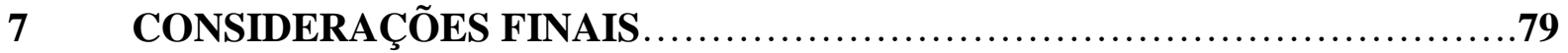

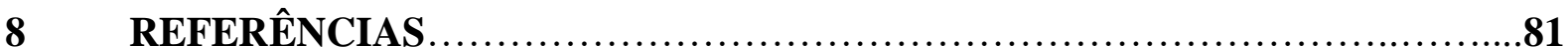

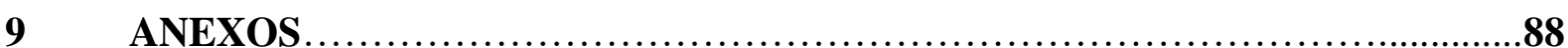




\section{INTRODUÇÃO}

Com o advento da internet ${ }^{l}$ e das redes sociais, o jornalismo vem se atualizando e passando por diversas mudanças. A rapidez das notícias, a qualidade e credibilidade foram fatores que permaneceram intactos e sobreviveram ao tempo e aos avanços tecnológicos. No entanto, os jornais tradicionais tentam se adaptar a multimidialidade, ao fim da limitação tempo e espaço e a nova relação com os leitores.

No Brasil, acontecimentos recentes trouxeram à luz diferentes veículos jornalísticos independentes, que estabelecem novas conexões com os usuários. Os acontecimentos foram as manifestações de junho de 2013 com reivindicações contra a Copa do Mundo e para a melhoria de serviços básicos como segurança, saúde e educação. Houve uma grande crítica vinda da sociedade em relação à apuração dos clássicos veículos de comunicação. Era necessária uma cobertura mais próxima do que estava acontecendo nas ruas, dos fatos que a imprensa tradicional não noticiava. Uma apuração aprofundada com a abordagem de uma outra perspectiva, diferente da tradicional. A Mídia Ninja ganhou espaço nas redes sociais com transmissões ao vivo, fotos e pontos de vistas dos manifestantes, como citado por Venício A. de Lima (2013), em entrevista ao jornal digital Pragmatismo Político "o ninja estava presente onde a grande mídia não estava."

Com a união de vozes de diferentes regiões do país, as casas coletivas da Mídia Ninja são locais de encontro e de debates. A análise do funcionamento dessa nova forma de produção de conteúdo é um ponto de estudo para o entendimento do presente e do futuro do jornalismo. Como são a cultura e o clima organizacional do coletivo, os processos organizacionais e as etapas internas para a produção das matérias são alguns dos pontos trabalhados nesta pesquisa.

O presente Trabalho de Conclusão de Curso tem como principal objetivo descobrir como é a cultura organizacional de um dos maiores jornais independentes do Brasil, a Mídia Ninja, na sede das cidades de Brasília e Belo Horizonte. Em uma época de convergências, na qual o jornalista é um multiprofissional, as mídias se conectam e a interatividade e rapidez são essenciais, entender como funcionam os veículos jornalísticos que estão ganhando força no contexto social é de grande relevância.

\footnotetext{
1 De acordo com Dênis de Moraes, “a internet é um ecossistema digital caracterizado por arquitetura descentralizada, multiplicação de fontes de emissão, disponibilização ininterrupta de dados, sons e imagens, utilização simultânea e interações singulares. ” (MORAES, 2007, p. 01)
} 
A investigação possui como uma de suas principais justificativas o cunho pessoal. $\mathrm{O}$ jornalismo independente inspira uma transformação na comunicação mundial. Jornalistas livres sem pressões comerciais e econômicas podem relatar as notícias de uma maneira mais profunda. O jornalismo faz parte da sociedade e desempenha o papel de relatar diferentes histórias e narrativas. Estudar as transformações que acontecem nessa área é apaixonante. $\mathrm{O}$ conteúdo, a profissão, a forma de relatar, tudo vem se transformando e alterando as futuras perspectivas desta área profissional.

Além disso, estudar os instrumentos do comunicador organizacional dentro de uma instituição de jornalismo independente é também estudar o local onde egressos do curso interessados na área de notícias poderão trabalhar. Não especificamente a Mídia Ninja, mas um jornal independente, alternativo à grande mídia. É mostrar as diferentes possibilidades de atuação de um profissional completo na área comunicacional, como é o caso do comunicador organizacional.

Dessa maneira, desenvolver uma análise de como o profissional de Comunicação Organizacional pode atuar nesse mercado inovador é essencial tanto para os estudantes e os já comunicadores, como também, para as empresas que podem, a partir deste estudo, perceber a necessidade de um trabalhador com conhecimentos estratégicos conectados aos comunicacionais. Já que "quando se fala em comunicação organizacional, temos que pensar sobretudo, na comunicação humana e nas múltiplas perspectivas que permeiam o ato comunicativo no interior das organizações" (KUNSCH, 2009, p. 70).

Em uma perspectiva social, é essencial compreender, também internamente, grupos como o Mídia Ninja. Com a realização de um trabalho diferenciado na área do jornalismo, a importância para a comunidade em saber quem são os produtores de conteúdo e como funciona a empresa por dentro é de grande relevância social. Esses procedimentos internos e a cultura organizacional interferem de forma decisiva na matéria finalizada, por isso a relevância da compreensão por uma perspectiva de dentro desse meio de comunicação tão atuante na sociedade.

Um outro ponto, é o atual contexto do jornalismo. Seus modelos de negócio estão em crise e existem vozes dissonantes com propostas diferentes. É interessante um olhar organizacional sobre essas propostas. Entendê-las é um caminho para a saída da crise. Dessa maneira, a escolha para a análise das sedes localizadas em Brasília e Belo Horizonte se deu porque a primeira sede localiza-se na capital do governo federal e é uma das principais fontes 
de informação do coletivo durante o ano de eleições e a segunda porque é um dos maiores pontos de encontro dos jornalistas ninjas.

O trabalho pretende analisar profundamente, com um olhar organizacional e inspirações antropológicas, o jornalismo independente no Brasil com o estudo de caso da Mídia Ninja. Os cenários, usuários e o contexto em que esse jornalismo cresce são de extrema importância para o diagnóstico dessa área no país. Dando assim, uma base para uma análise interna dos novos fluxos de trabalho e de organização do jornalismo.

Em busca de entender a cultura organizacional da Mídia Ninja, o trabalho pretende, inicialmente, detalhar o objeto de estudo, que no caso é a organização Narrativas Independentes Jornalismo e Ação, a Mídia Ninja. A pesquisa se propõe a contextualizar as mudanças tecnológicas e o surgimento do jornalismo independente e do jornalismo cidadão e uma evolução do newsmaking. Em uma terceira fase, conceituar os temas cultura organizacional, clima organizacional e a narrativa jornalística audiovisual faz-se necessário para definir os processos organizacionais do jornal por meio dos instrumentos metodológicos utilizados: questionários, entrevista em profundidade e observação participante. 


\section{MÍDIA NINJA: UM LIDE COMPLETO}

\subsection{A rede Fora do Eixo e a Pós TV}

O ano é 2013. Durante os meses de junho e julho, ocorreram no Brasil uma série de manifestações de rua que se iniciaram em São Paulo e tomaram todo o país. Com a reivindicação inicial contra o aumento do preço do transporte coletivo da cidade, o movimento "não são só 20 centavos" tomou outra proporção e abarcou outros desejos da população brasileira. De acordo com a matéria publicada no site do jornal $\mathrm{Nexo}^{2}$,

o mês de junho de 2013 ficou marcado por uma onda de protestos que, a partir de
São Paulo, se espalhou por várias cidades brasileiras, mobilizando milhares de
pessoas no que se tornaria, naquele momento, a maior série de manifestações de rua
desde o movimento pelo impeachment do presidente Fernando Collor, 21 anos antes.
Originalmente, os manifestantes se opunham ao aumento no preço das passagens de
ônibus, de R\$ 3 para R\$ 3,20. Aos poucos, no entanto, a pauta se ampliou. A frase
"não é por R\$ $0,20 "$, escrita em vários muros da capital paulista, deixou claro o
desejo de extrapolar a reivindicação original.
(CHARLEAUX, 2017)

Com as mobilizações organizadas nas redes sociais, principalmente no Facebook e no Twitter, as ruas das capitais do país ficaram, durante o mês de junho, repletas de manifestantes de diversos segmentos sociais que reivindicavam, além do transporte público de qualidade, melhorias na saúde, na educação, na segurança e o fim da corrupção. Ainda de acordo com o jornal Nexo, Bruno Torturra, um dos fundadores da Mídia Ninja, entrevistado para a matéria ${ }^{3}$, afirmou que "cada vez mais acho que as manifestações de junho foram um fenômeno comunicacional com implicações políticas, mais do que um fenômeno político com implicações comunicacionais" (TORTURRA, 2017).

Nesse contexto, muitos acreditaram que a Mídia Ninja surgiu durante as manifestações de junho de 2013. Naquele período, a organização ganhou mais espaço e voz entre os outros canais de jornalismo independente e mesmo do jornalismo tradicional brasileiro, no entanto, o começo dessa trajetória é relativamente anterior ao grande marco. Mas iremos chegar lá.

A história da Mídia Ninja começa bem antes da mesma existir. Precisamos retornar ao início do coletivo Fora do Eixo (FdE), grupo que gerou o espaço, a rede e o diálogo que possibilitaram a criação da Mídia Ninja. O FdE nasceu em meados de 2005, com a integração inicial das cidades de Cuiabá (Mato Grosso), Rio Branco (Acre), Londrina (Paraná) e Uberlândia (Minas Gerais). O grupo tinha como objetivo inaugural promover o intercâmbio

\footnotetext{
${ }^{2}$ Disponível em:

$<$ https://www.nexojornal.com.br/expresso/2017/06/17/O-que-foram-afinal-as-Jornadas-de-Junho-de-2013.-E-noque-elas-deram >

${ }^{3}$ Idem.
} 
de artistas fora do centro de produção cultural brasileiro. Depois, assumiu como propósito reunir e divulgar coletivos culturais que promoviam apresentações não só musicais, mas também performances artísticas, exibições de filmes, peças teatrais, exposições de artes visuais e outros eventos fora do eixo Rio-São Paulo e também discutir sobre políticas públicas para a cena cultural alternativa.

Com a realização de festivais como Grito do Rock ${ }^{4}$, Festival Fora do Eixo ${ }^{5}$ e também de $\operatorname{congressos}^{6}$ e encontros, a rede não-governamental ganhou cada vez mais força dentro do cenário cultural no interior do Brasil, atingindo os grandes polos artísticos do país. Houve a criação de uma rede física, com mais de vinte casas coletivas Fora do Eixo espalhadas pelo país como também uma rede de estrutura de tecnologia social por meio de um processo altamente integrado e articulado, de acordo com Rafael Vilela, um dos fundadores da Mídia Ninja, em entrevista ${ }^{7}$ ao canal do Youtube denominado Acontecendo Aqui. No site Portal da Transparência Fora do Eixo, o grupo define-se como

\begin{abstract}
uma rede colaborativa e descentralizada de trabalho constituída por coletivos de cultura pautados nos princípios da economia solidária, do associativismo e do cooperativismo, da divulgação, da formação e intercâmbio entre redes sociais, do respeito à diversidade, à pluralidade e às identidades culturais, do empoderamento dos sujeitos e alcance da autonomia quanto às formas de gestão e participação em processos sócio-culturais, do estímulo à autoralidade, à criatividade, à inovação e à renovação, da democratização quanto ao desenvolvimento, uso e compartilhamento de tecnologias livres aplicadas às expressões culturais e da sustentabilidade pautada no uso e desenvolvimento de tecnologias sociais. (PORTAL DA TRANSPARÊNCIA FORA DO EIXO, 2009)
\end{abstract}

Em 2009, houve a criação da carta de princípios da organização, esta que se tornou um representativo projeto da contracultura ${ }^{8}$ brasileira. $\mathrm{O}$ item 8.4 da carta refere-se ao estímulo à inovação, às práticas livres de comunicação, ao desenvolvimento e criação de tecnologias colaborativas e de livre acesso que são alguns dos pilares da rede. Dois anos após a carta,

\footnotetext{
${ }^{4}$ Segundo Portal da Transparência do Fora do Eixo, "O Grito Rock Mundo é um festival colaborativo realizado pelo Fora do Eixo, iniciativa financiada pelo Fora do Eixo Card e produzido com o apoio do TNB Toque No Brasil.” Disponível em: <http://foradoeixo.org.br/2014/02/18/grito-rock-manaus-reune-produtores-pararealizacao/ >

${ }^{5}$ O Festival Fora do Eixo se propõem a levantar questões relacionadas ao novo cenário da música independente no Brasil, realizado em diversas cidades do Brasil pela organização Fora do Eixo. Disponível em: $\langle$ http://festival.foradoeixo.org.br/historico/ $>$

${ }^{6}$ Congresso Fora do Eixo, de acordo com o portal online, é o evento para "desnudar questões envolvendo ativismo, conexões em rede, economia colaborativa, formação livre e midialivrismo" que reúne diferentes coletivos.

${ }^{7}$ Disponível em: <https://www.youtube.com/watch?v=Gf5LbTbi2mg >

${ }^{8}$ Contracultura é um movimento de contestação contra a cultura dominante. De acordo com Antônio Risério, "contracultura foi um movimento internacional (com origem em 1970) que teve suas ramificações no Brasil e acabou sendo difundido durante a ditadura" (RISÉRIO, 2006, p. 26). Algumas das das características desse fenômeno são a crítica à comunicação de massa e ao sistema comercial capitalista vigente.
} 
durante a Marcha da Maconha $^{9}$ de São Paulo em 2011, aconteceram várias repressões policiais que indignaram membros do FdE e comunicadores como Bruno Torturra, então jornalista da revista $\operatorname{Trip}^{10}$, que participavam da passeata para a legalização do comércio e uso da maconha.

Indignado com a violência policial, Bruno, que não era muito conectado às redes sociais, escreveu um texto de desabafo e compartilhou vídeos ao vivo na sua conta do Twitter. Em poucas horas, essa postagem e as imagens tinham mais de 45 mil visualizações e como ressaltado pelo jornalista durante palestra ${ }^{11}$ realizada no TEDx no bairro da Liberdade em São Paulo, ele nunca teve tamanha repercussão e interação com o público durante onze anos de carreira.

Uma outra marcha foi organizada em São Paulo para defender a liberdade de expressão e ficou conhecida como Marcha da Liberdade. Durante essa manifestação, colaboradores do Fora do Eixo e Bruno Torturra realizaram transmissões ao vivo mostrando em tempo real os acontecimentos da marcha. A partir desse momento, surgiu a PósTV elaborada para ser o canal de web comunicação do FdE, e de acordo com Bruno, um dos fundadores da mesma, "é uma rede de streamers, de pessoas que transmitem ao vivo no país inteiro" (TORTURRA, 2014).

A PósTV foi um laboratório de testes, precursor da Mídia Ninja, no qual diferentes formatos de projetos foram lançados com abordagens distintas e produzidos todos de forma colaborativa. De acordo com a página ${ }^{12}$ do canal de comunicação no Facebook, a PósTV "é a verdadeira TV aberta. Onde não existe censura, as pessoas falam livremente e não se depende de patrocínio, o patrocinador é o povo, as entidades e os movimentos sociais" (PÓSTV, 2011). Houve a utilização de diversas mídias e instrumentos para gravação de vídeos e áudios, incluindo smartphones, que assim como a internet, foram uma das grandes ferramentas que contribuíram para o início da caminhada de construção da democratização da comunicação. $\mathrm{O}$ número de espectadores foi tão alto que o canal realizou um programa no Profissão Repórter, dirigido por Caco Barcelos na rede Globo, que mostra a realidade do cotidiano dos jornalistas com pautas que não são muito abordadas nos grandes telejornais da emissora.

\footnotetext{
9 A Marcha da Maconha é um evento mundial que ocorre anualmente em diversas localidades no planeta. Iniciada em 1944, a marcha defende a legalização da substância e objetiva favorecer o debate da regulamentação do comércio e do uso.

${ }^{10}$ Segundo site da UOL, onde a revista online é hospedada, a Trip foi lançada em 1986 e a revista trata a cada mês dos mais variados temas - da política ao sexo, da cultura de praia às novas relações com o trabalho, da alimentação às drogas, da segurança pública ao novo ativismo. Disponível em: <http://www.tripeditora.com.br/marcas-trip/ >

11 Disponível em: 〈 https://www.youtube.com/watch?v=2PlcMKNo_1U >

12 Disponível em: < https://pt-br.facebook.com/pg/canalpostv/about/?ref=page_internal $>$
} 
Um dos projetos de maior sucesso da $w_{e b t v}{ }^{13}$ foi a série de programas Supremo Tribunal Liberal que consistia em entrevistas de passantes na rua Augusta pelo jornalista Cláudio Prado. Sujeito a todas as interferências do ambiente, o sofá colocado na calçada da rua, era o cenário das conversas. De moradores de rua a porteiros, Cláudio transitava por assuntos como tráfico de drogas e a vida noturna cultural de São Paulo. A equipe formada por Bruno Torturra, Rafael Vilela e outros colaboradores realizava a produção e diferentes testes de luz e de câmera e o som era captado por dois microfones dos quais um era passado aos entrevistados e o outro ficava com Cláudio. O apresentador do programa justificou o seu formato, "sou um ninja septuagenário, então em vez de correr atrás de pessoas, coloquei meu sofá na correria da Augusta", como relatado em entrevista a Elizabeth Lorenzotti (2014, p. 06) no livro O jornalismo do século XXI - modelo Mídia Ninja.

Durante dois anos, a PósTV desenvolveu uma série de trabalhos voltados para pautas culturais, sociais e políticas e adquiriu mais de 10 mil inscritos no canal do Youtube e 20 mil curtidas na página do Facebook. Comentários de internautas, postagens de feedbacks sobre matérias e sugestões de pautas eram recebidos nas redes sociais, resultados que mostraram uma grande interação do público com o projeto. De acordo com Rafael Vilela, um dos primeiros integrantes da PósTV e um dos criadores da Mídia Ninja, jornalismo

não é mais só produzir o conteúdo como emissor e esperar que você tenha um
receptor que vá receber esse conteúdo. Eu acho que tem um novo paradigma de
comunicação que está colocado nessa era digital, que é entender que todo mundo é
um produtor potencial de conteúdo e um replicador também. E, mais do que tudo,
que é um público ativo, não é um público que fica esperando. Ele está sempre
demandando, enviando proposta, produzindo e enviando conteúdo. É uma troca,
mais do que uma emissão de uma mensagem como se entendia no século XX. O
século XXI traz essa necessidade da troca, em tempo real, o tempo todo, de forma
muito honesta.
(VILELA,

Consequentemente, o Fora do Eixo cresceu por meio da divulgação dos congressos e festivais na tv online e mobilizou mais de dois mil colaboradores no país. Em 2012, houve o lançamento em abril da Casa Fora do Eixo em Belo Horizonte, Minas Gerais e a realização de mais festivais regionais no norte, nordeste, centro-oeste e no sul do Brasil.

\subsection{Origem da Mídia Ninja e as "Jornadas de junho"}

No ano de 2013, ocorreu o $3^{\circ}$ Fórum Mundial de Mídia Livre seguido pela Fórum Social Mundial, realizados em Túnis, capital da Tunísia no mês de março. Os eventos

\footnotetext{
${ }^{13}$ Webtv é a televisão online, via internet. Elementos como áudio e vídeo podem ser assistidos por meio de um computador ou smartphone.
} 
reuniram coletivos midialivristas de diversos países para debater a democratização da comunicação, iniciativas de mídia livre mundiais e a regulamentação da mídia em panoramas internacionais. Organizados em um país no qual a força das redes sociais e da comunicação livre foi exemplo para a união de pessoas em prol da luta pelos seus direitos durante a Primavera Árabe ${ }^{14}$, que no entanto, esses indivíduos ainda lutam pela construção de uma mídia livre e pela liberdade de expressão, os eventos repletos de debates e temas inovadores, onde a comunicação é vista como direito humano, foram o berço ideal para o lançamento da Mídia Ninja.

Fundada por Bruno Torturra, Rafael Vilela, Felipe Altenfelder, Driade Aguiar, Pablo Capilé e outros colaboradores, Narrativas Independentes Jornalismo e Ação, a Mídia Ninja, é um coletivo de comunicadores independentes que narram histórias as quais os veículos de comunicação convencionais não se aventuram a narrar. Os ninjas defendem a diversidade, movimentos sociais e visões "sem censura e nem cortes". Não acreditam no mito da imparcialidade, na verdade, valorizam "a multiplicidade de parcialidades. Nossas pautas são nossas causas. Acreditamos no movimento e na transformação social, a partir de uma experiência radical de mídia livre e distribuída, a serviço de uma nova narrativa social, mais comunitária e mais afetiva"' (MÍDIA NINJA, 2014a).

Sem roteiro definido, a Mídia Ninja começou com o canal do Youtube, página no Facebook e perfil no Twitter. Através da utilização de redes sociais, câmeras e smartphones, jovens de diferentes regiões do Brasil se organizaram em rede para disponibilizar o acesso à comunicação de forma colaborativa e horizontal por meio de transmissões via live streaming ${ }^{15}$. Temas pouco noticiados, considerados "delicados" e pouco analisados pela

\footnotetext{
${ }^{14}$ Primavera Árabe foi um movimento iniciado em Tunís, capital da Tunísia em janeiro de 2011 que se espalhou pelo Oriente Médio provocando diversas mudanças políticas. O nome fazia referência a Primavera de Praga, na qual, de acordo com o jornal Nexo, jovens da Tchecoslováquia protestaram contra a dominação soviética em 1968. Num sentido mais simbólico, no entanto, a "primavera" era uma referência à ideia de despertar e de renovação em países nos quais jovens politicamente engajados, insatisfeitos com as condições econômicas e conectados pelas novas tecnologias da informação pressionaram por reformas democráticas em regimes controlados há décadas por ditadores. Após a auto-imolação do jovem Tarek Mohamed Bouazizi em Tunís, no ano de 2011, houve uma série de manifestações de rua, organizadas pelas redes sociais, que se espalharam pela Tunísia e pelo Oriente Médio. Os resultados foram a queda de ditadores que estavam há mais de 10 anos no poder. Na Tunísia, Ben Ali renunciou, na Líbia, Muammar Kadaffi morreu, no Iêmen, Abdullah Saleh foi deposto, na Síria instalou-se a guerra contra o ditador Bashar al-Assad que dura até hoje, ano de 2018. Disponível em: < http://politike.cartacapital.com.br/o-que-deu-errado-com-a-primavera-arabe/ >.Disponível em: <https://www.nexojornal.com.br/expresso/2018/01/10/Quais-as-raz\%C3\%B5es-dos-protestos-no-7\%C2\%BAanivers\%C3\%A1rio-da-Primavera-\%C3\%81rabe >
}

15 De acordo com Almeida e Evangelista (2013, p. 04) "Live streaming é a transmissão ao vivo de dados via rede. Por meio desta tecnologia, informações multimídia podem ser facilmente distribuídas e acessadas em tempo real. Por meio do streaming (fluxo de mídia), as informações são reproduzidas assim que chegam ao usuário, em modelo semelhante ao rádio ou TV aberta, geralmente não sendo arquivadas por ele.” 
grande mídia são enfrentados e colocados em pauta pelos ninjas que se propõem a realizar a transmissão de entrevistas e matérias possibilitada através do processo em rede de comunicação independente que conecta pessoas do país todo.

Os produtores de conteúdo da Mídia Ninja se consideram midialivristas, conceito este definido como "cidadãos multimídia, que atuam em iniciativas inspiradas na dinâmica do compartilhamento e na construção da cultura do comum: internet, fanzines comunitários, rádios comunitárias e etc" (LORENZOTTI, 2014, p. 04). Divididos em colaboradores e membros da equipe orgânica, estes que moram em alguma das casas do Fora do Eixo, o grupo, em 2013, contava com cerca de 2.000 trabalhadores. A lógica financeira do coletivo acontece em rede, o Fora do Eixo participa de diferentes editais públicos para financiamento de festivais que acabam retornando para a Mídia Ninja e esse dinheiro é usado para o sustento dos jornalistas que moram nas casas coletivas. A desmonetarização, a adoção de uma moeda própria (Fora do Eixo Card) e o não pagamento de salários são algumas das características do movimento.

Segundo membros da Mídia Ninja, a organização surgiu para disputar narrativas, dar luz a temas que não poderiam entrar dentro das casas brasileiras por meio dos veículos tradicionais. Dar visibilidade às pautas produzidas por participantes de movimentos sociais, ativistas, militantes, pessoas marginalizadas. Esses que não só recebem a notícia como também auxiliam na produção para a mídia, o que caracteriza o jornalismo cidadão, conceito que será abordado nos próximos capítulos. De acordo com Bruno Torturra, um dos fundadores, a Mídia Ninja, “é a quebra de uma narrativa midiática única através do jornalismo-cidadão". (TORTURRA, 2013a). O propósito é produzir, divulgar e debater com novas fontes, com novas referências, com um novo canal alternativo de comunicação. De acordo com os ninjas, é ser mídia livre. Representar uma ruptura com a produção tradicional das notícias e com a abordagem que são veiculadas. Midiativismo, ciberativismo, midialivrismo, movimento hacker e representatividade são conceitos que agora estão conectados ao jornalismo como nunca antes e serão aprofundados nos próximos capítulos.

Segundo a Mídia Ninja, a notícia não é um produto, mas é um processo de comunicação, de troca, de diálogo realizado entre os ninjas e o público que também não é visto como consumidor - como a mídia tradicional enxerga - mas como um produtor e crítico de conteúdo que realiza feedbacks e comentários pautando as abordagens da organização. É a mudança de visão, do jornalismo comercial para o jornalismo colaborativo. É tentar entender 
a complexidade do mundo, não abordando tão somente uma visão dual da realidade. De acordo com Almeida e Evangelista,

As mídias independentes se propõem a destacar enquadramentos diferenciados dos que estampam os grandes jornais ou são exibidos nos noticiários televisivos. Com isso, buscam produzir informações desprendidas de interesses mercadológicos e apresentar outros ângulos dos fatos, em perspectivas que geralmente as grandes empresas não se interessam ou não atentam para abordar. (ALMEIDA; EVANGELISTA, 2013, p. 04)

Conseguir representar diferentes grupos da sociedade e desenvolver um discurso parcial são pontos defendidos pela Mídia Ninja. "A nova objetividade vem da transparência de como essa informação é produzida", afirma Bruno Torturra (2013b), em entrevista ${ }^{16}$ ao programa Roda Vida do canal da TV Cultura. Sendo assim, o canal de comunicação feito pelos ninjas tem um posicionamento declarado que é colocado no site da iniciativa, evidenciando que

a Mídia Ninja tem lado. Acreditamos que imparcialidade não existe, e por isso assumimos nosso lugar de fala a partir da defesa da democracia, da diversidade cultural e de um posicionamento editorial transparente e direto. Nossa editoria é coletiva e defende o interesse público, o direito à informação e ampla visibilidade de pautas e movimentos sociais ligados aos direitos humanos, comunicação, cultura, moradia, política, economia, meio ambiente, à causa indígena e outras agendas que dialogam com os desafios do século XXI. (MÍDIA NINJA, 2014b)

De acordo com Elizabeth M. Veloso, "a responsabilidade dos meios de comunicação perante a construção permanente da democracia é por demais grandiosa para que interesses empresariais, privatistas e sem qualquer responsabilização e controles democráticos possa levá-la a cabo" (FONSECA, 2011, p. 66). A Mídia Ninja, acredita que desempenha o papel de ser um ponto fora da curva e pretende iniciar o surgimento de mais pontos que não sejam apenas a repetição de um discurso pautado em interesses econômicos e políticos. "Trata-se de uma ecologia de produção de conteúdo que tem capacidade de incidir diretamente nas disputas de imaginário contemporâneas e colaborar com a obtenção de conquistas públicas da sociedade" (MÍDIA NINJA, 2013a).

O lançamento da Mídia Ninja em março de 2013 não trouxe grande reconhecimento de público imediatamente, no entanto, no final do mês de junho do mesmo ano o número de visualizações nas redes sociais da organização chegou a 100 mil e a Ninja foi notícia em jornais internacionais como The New York Times ${ }^{17}$, The Guardian ${ }^{18}$, entre outros. No dia 13

\footnotetext{
${ }^{16}$ Disponível em: < https://www.youtube.com/watch?v=kmvgDn-lpNQ >

17 Disponível em: < https://www.nytimes.com/2013/06/21/world/americas/brazil-protests.html >
} 
de junho, durante manifestação para a diminuição dos preços das passagens de ônibus em São Paulo, iniciada pelo Movimento Passe Livre (MPL), manifestantes sofreram duras repressões policiais. O MPL

entende a circulação e a mobilidade nas cidades como processos centrais para realização do capital, mas também como estratégicas para o usufruto dos direitos mais básicos, como a liberdade de ir e vir, e a própria existência social nas cidades. Os trabalhadores, no caso, seriam os maiores afetados, pois têm o direito à mobilidade quase que limitado ao trajeto casa-trabalho, interditando o acesso a outros espaços sem finalidade tão instrumentais - culturais, de lazer, esportivos etc. (FONSÊCA, 2013, p.8)

As manifestações começaram com a exigência da diminuição de vinte centavos nas passagens de ônibus, mas após o episódio de diversos conflitos com a polícia, as reivindicações que estavam espalhadas por diferentes regiões do Brasil se uniram e tomaram as ruas de mais de 100 cidades. Incluindo pedidos de direito à cidade como melhorias na mobilidade urbana, nos serviços de saúde, educação e segurança oferecidos pelo Estado e o fim da corrupção, utilizou-se como lema a hashtag \#nãosãosó20centavos.

As manifestações também eram contra os investimentos na Copa das Confederações e na Copa do Mundo da Federação Internacional de Futebol (FIFA) que ocorreu no ano de 2014 no Brasil. Em 2016, de acordo com o Jornal Nexo, cinco dos doze estádios reformados para a Copa do Mundo no Brasil estavam sendo citados em investigações da Polícia Federal e da Procuradoria Geral da República e, todas as empresas ${ }^{19}$ que coordenaram os projetos dos estádios eram investigadas na Operação Lava-Jato ${ }^{20}$. Suspeitas de estádios superfaturados e de esquemas de corrupção para desvios de dinheiro geraram uma onda de insatisfação. "O gigante acordou", "vamos pra rua" e outros bordões viralizaram nas redes sociais e eram os escritos dos cartazes dos manifestantes.

A violência do Estado contra a população mais pobre e o desaparecimento de pessoas foram um dos temas abordados nos protestos brasileiros. Em meio às manifestações de julho,

\footnotetext{
${ }^{18}$ Disponível em < https://www.theguardian.com/world/2013/aug/29/brazil-ninja-reporters-stories-streets >

19 Os estádios investigados eram a Arena Corinthians (SP), Maracanã (RJ), Mané Garrincha (DF), arena Amazônia (AM) e Arena das Dunas $(\mathrm{RN})$. As empreiteiras investigadas na operação Lava-Jato eram a Odebrecht, a Andrade Gutierrez e a OAS. Disponível em: <https://www.nexojornal.com.br/expresso/2016/04/25/Quais-os-est\%C3\%A1dios-da-Copa-citados-em-casos-decorrup $\% \mathrm{C} 3 \% \mathrm{~A} 7 \% \mathrm{C} 3 \% \mathrm{~A} 30>$

20 Deflagrada em março de 2014 e conduzida pelo juiz Sérgio Moro, começou com a "investigação sobre conexões entre doleiros e políticos do Paraná. Conforme avançou, desvendou diversos esquemas de corrupção interligados entre si” (VENTURINI E ARAGÃO, 2018). Disponível em: <https://www.nexojornal.com.br/explicado/2018/03/16/Lava-Jato-a-origem-e-o-destino-da-maioropera\%C3\%A7\%C3\%A3o-anticorrup\%C3\%A7\%C3\%A3o-do-pa\%C3\%ADs >
} 
o pedreiro, Amarildo dos Santos ${ }^{21}$, morador da favela da Rocinha nunca mais foi encontrado depois de ter sido levado por uma viatura da polícia militar. O caso até hoje não foi solucionado e na época levou a uma comoção nacional, aumentando o número de pessoas que foram às ruas. De acordo com Castells (2013), movimentos sociais dependem não só das desigualdades enfrentadas pela população, mas também de aspectos emocionais, "a importância de emoções como raiva, entusiasmo e medo que são relacionadas respectivamente a busca por justiça, engajamento e superação" (PEREIRA, 2013, p. 410). O autor ainda estabelece uma conexão com a Primavera Árabe no Oriente Médio, com os Indignados ${ }^{22}$ na Espanha e é possível perceber também a conexão com as manifestações de junho e julho no Brasil.

\begin{abstract}
$\mathrm{O}$ autor fornece um panorama sobre as características comuns dos movimentos e nota que só puderam ser percebidos como tal a partir do momento em que ocuparam os espaços urbanos, concluindo: "O espaço do movimento é sempre feito de uma interação do espaço dos fluxos na internet e nas redes de comunicação sem fio com o espaço dos lugares. " (p. 160). Aponta, ainda, outras características, como a espontaneidade, o trânsito deles entre as questões locais e globais, o poder das imagens, autorreflexão, horizontalidade de suas redes, percebendo que tais movimentos produziram, internamente, seus próprios antídotos contra a disseminação dos valores sociais e costumes que combatiam. (PEREIRA, J. 2013, p. 410).
\end{abstract}

Enquanto, a mídia tradicional transmitia as notícias nomeando os manifestantes como "vândalos", "baderneiros" e "arruaceiros" e "cobrindo manifestações de helicóptero, acreditando que é um bom jornalismo" (VILELA, 2013), a Mídia Ninja participou das manifestações "no chão, junto com as pessoas, entendendo aqueles anseios" (VILELA, 2013), realizou sua inserção dentro dos protestos e colocou a voz das ruas no foco por meio de uma cobertura engajada. Como levantado por Deborah Potter (2011, p. 76) no Manual do Jornalismo Independente, "a imprensa livre vem sendo chamada de oxigênio da democracia, porque uma não consegue viver sem a outra".

\footnotetext{
${ }^{21}$ De acordo com matéria da Carta Capital, o pedreiro Amarildo dos Santos, 43 anos, foi visto pela última vez no dia 14 de julho de 2013 sendo levado de casa por policiais da Unidade de Polícia Pacificadora da comunidade da Rocinha no Rio de Janeiro. Esse desaparecimento trouxe à tona o debate sobre a política de segurança pública e atuação bruta dos policiais nas favelas e comunidades. Disponível em: $<$ https://www.cartacapital.com.br/sociedade/desaparecimento-do-pedreiro-amarildo-preocupa-e-comove-no-rio1453.html >

${ }^{22}$ Segundo matéria do El País, no dia 15 de maio de 2011, o movimento 15-M, Indignados, começou com uma manifestação na praça do Sol no centro de Madri. Pela luta de uma democracia real, de novas vias de participação e transformações democráticas e pacíficas, as ruas da Espanha foram tomadas de manifestantes pelo movimento da Marcha Popular Indignada. Disponível em: 〈https://brasil.elpais.com/brasil/2015/05/15/internacional/1431679318_951340.html >
} 
Surgimos em meio à multidão. Num momento decisivo em que a história do país se pôs diante de nós. Fomos os olhos, a voz e o coração de milhares de pessoas. Transmitindo de dentro os acontecimentos, nos envolvemos e fomos parte do processo de transmutação política de nossa geração. (MÍDIA NINJA, 2014a).

Fazer política com o celular, de acordo com Humberto Laudares, colunista do jornal Nexo, foi a maior herança das manifestações de 2013,

O maior legado das manifestações de 2013 foi deixar claro que o cidadão, empunhado de seu telefone, pode se organizar e fazer política. Nesse sentido, 2013 foi um grande grito de insatisfação com a representação política, com as mais diferentes mensagens e sotaques. No entanto, encorajou muitos movimentos da sociedade civil, com diferentes pautas e vertentes ideológicas, a se manifestar nos anos seguintes. Diria que inspirou também outros movimentos a se organizarem para atuar em rede. Espero que 2013 invada 2018, só que dessa vez o cidadão não ocupe o lado de fora do Congresso Nacional, mas a representação política de fato após as eleições. O ano de 2013 protestou contra essa política arcaica. Quem sabe a sociedade amadureceu o suficiente para renova-la dessa vez. (LAUDARES, 2017).

Um dos episódios no qual vídeos produzidos pela Mídia Ninja puderam ilustrar depoimentos e conseguir inocentar presos durante as manifestações foi o caso do estudante Bruno Teles, liberado após a exibição de imagens que comprovaram que ele não havia arremessado coquetéis molotov contra os policiais durante os protestos. No Rio de Janeiro, em um outro caso, ainda durante as manifestações de julho, dois ninjas - Filipe Peçanha e Filipe Gonçalves - foram presos por estarem gravando e filmando os acontecimentos das marchas. Gritos como "Ei polícia, cadê a Mídia Ninja?" ecoaram da multidão após as prisões dos integrantes do coletivo Ninja. Essa repressão à liberdade de expressão foi noticiada em jornais como o The Washington Post ${ }^{23}$. De acordo com Lorenzotti,

\begin{abstract}
A projeção dos Ninjas não impediu - ao contrário, talvez tenha provocado - a prisão de dois de seus integrantes, Filipe Peçanha e Filipe Gonçalves, a 22 de julho, primeiro dia da visita do papa ao Rio de Janeiro, durante as transmissões da manifestação contra o governador na frente do Palácio da Guanabara, por "incitação à violência". Quando foi preso, o ninja Filipe Gonçalves ainda conseguiu gravar dentro da delegacia. No final do vídeo gravado por ele mesmo, pois estava transmitindo, já quase sem imagens, ouve-se nitidamente um policial ameaçar: "Quem estiver usando celular vai ser preso! ”. (LORENZOTTI, 2014, p. 20).
\end{abstract}

Esse período de dois meses - junho e julho - de 2013 ficou conhecido "como o importante momento em que as grandes empresas de mídia deixaram de pautar a agenda do debate público do país. E quando a mídia de massa e sua lógica centralizadora foram superadas pelas redes digitais, pela cultura colaborativa e sua lógica descentralizada"

\footnotetext{
${ }^{23}$ Disponível em: <https://www.washingtonpost.com/news/worldviews/wp/2016/09/05/watch-brazilian-policeattack-anti-impeachment-protesters/?utm_term $=.74 \mathrm{c} 765 \mathrm{~b} 767 \mathrm{bd} \&$ noredirect=on $>$
} 
(FELICE, 2013). A mídia alternativa começou a pautar a grande mídia em 2013. Grandes telejornais do país pediram perdão a população por terem utilizado termos como vandalismo para descrever os manifestantes e começaram a utilizar vídeos produzidos pela Mídia Ninja para retratar as manifestações. A mídia alternativa trouxe um mosaico de multiparcialidades, de acordo com Daniel Fonseca,

os meios de comunicação tiveram um papel decisivo nos protestos. Enquanto as
emissoras comerciais buscaram, no início, estigmatizar e criminalizar os
manifestantes como "vândalos", foram pressionadas a mudar, ainda que
parcialmente, sua rota editorial com os excessos da violência policial. A imprensa
alternativa acompanhou os acontecimentos nas ruas ao vivo nas redes sociais,
assegurando uma diversificação de informação e de interpretações alternativas.
Contribuiu, assim, para que a discussão sobre a democratização da comunicação
ganhasse espaço na agenda pública.
(FONSECA, 2013, p. 01)

A Mídia Ninja surgiu durante o período de uma das maiores crises do jornalismo tradicional. Crise essa definida em duas partes: estrutural, por conta do modelo de negócio não adaptado à internet e às novas tecnologias e também uma crise de credibilidade por ter deturpado notícias e contradito fatos durante períodos como o golpe de Estado e a instauração da ditadura militar entre outros episódios. De acordo com matéria do jornal digital Carta Capital $^{24}$,

a imprensa foi arauto da trama golpista contra o presidente João Goulart. Sempre conservadores, os 'barões da mídia' brasileira agem na fronteira do reacionarismo. Apoiar golpes, por isso, não chega a ser exatamente novidade. Alardeiam o princípio do liberalismo sem, no entanto, se comprometer com a democracia. Assim promovem feitiços, como o de 1964, e tornam a própria imprensa vítima da feitiçaria. (DIAS, 2013).

Para ilustrar, Ramonet defende que "os cidadãos desconfiam de uma imprensa que pertence a um punhado de oligarcas, que já controlam amplamente o poder econômico e que, frequentemente, são coniventes com os poderes políticos. ” (RAMONET, 2012, p.45).

\subsection{Cinco anos de desafios, polêmicas e crescimento}

Um dos grandes desafios enfrentados pela Mídia Ninja era a forma como vídeos eram divulgados nas redes sociais. Por meio de plataformas como o Facebook, Youtube, Twitter e Google Hangout há a possibilidade da produção de material ao vivo, transmitido e produzido

\footnotetext{
${ }^{24}$ Disponível em: < https://www.cartacapital.com.br/politica/a-midia-na-ditadura >
} 
via streaming ${ }^{25}$ para e pelo público que segue a página. No entanto, há de acordo com "Moretzsohn (2006) o alerta para o risco da atividade jornalística, por sua difusão sem controle, mediante a adoção do lema 'publicar, então filtrar' em substituição ao 'filtrar, então publicar'”. (TARGINO, 2009, 53).

A entrevista ${ }^{26}$ do ex-prefeito do Rio de Janeiro, Eduardo Paes, em 2014 em resposta às manifestações de 2013 e divulgada ao vivo na página do Facebook da Mídia Ninja obteve duras críticas dos internautas em relação a forma como foi conduzida. A falta de cortes e de objetividade em algumas perguntas deixou a matéria longa e retórica. Os ninjas receberam os feedbacks negativos e confirmaram o não preparo ou roteiro para a realização da conversa. De acordo com matéria ${ }^{27}$ do Observatório de Imprensa, "falta de objetividade, desorganização e perguntas fora da alçada do prefeito marcaram o encontro, que durou cerca de duas horas. Logo depois, em nota publicada no Facebook, o grupo admitiu as falhas. ', (DINIZ, 2013).

O planejamento dos novos fluxos organizacionais não se caracterizou como o único problema inicial da Mídia Ninja. No âmbito estrutural, a rede de telefonia brasileira e o sinal 3G eram (e ainda são) de uma qualidade péssima e vídeos como os da Mídia Ninja demoram nos processos de upload, download e para carregar na transmissão ao vivo. Além disso, a página, em 2013, foi bloqueada no Facebook durante algumas horas, após usuários denunciarem postagens com teor impróprio ou pornográfico depois de postagens da manifestação anti-cura gay e anti-Feliciano.

Jornalistas e colaboradores que moravam nas casas Fora do Eixo, começaram em 2013 a analisar possibilidades de financiamento além da rede, como crowdfunding $^{28}$, tecnologias para converter curtidas em microfinanciamentos para cada texto e foto e também financiamento de movimentos sociais. De acordo com Rafael Vilela, um dos fundadores da Mídia Ninja,

houve durante um primeiro momento do coletivo Fora do Eixo, um momento de articulação, no qual fizemos com que os três coletivos iniciais (Rio Branco, Londrina e Cuiabá) virassem 200. Depois a gente passa por um processo de capacitação e troca de fluxos de metodologia, onde cada um desses pontos ensina ao outro o que faz e como faz. E hoje a gente vive muito forte esse ciclo da

\footnotetext{
${ }^{25}$ Streaming é o termo na língua inglesa utilizado para definir transmissão audiovisual ao vivo.

${ }^{26}$ Disponível em: <https://www.youtube.com/watch?v=fdRx3kVQmTo >

${ }^{27}$ Disponível em: $<$ http://observatoriodaimprensa.com.br/imprensa-emquestao/o_jornalismo_em_tempo_real_da_midia_ninja/ $>$

${ }^{28}$ Crowdfunding é o financiamento coletivo realizado por meio de plataformas online para a realização de algum projeto social, profissional ou pessoal. De acordo com Flávia Cocate (2011, p. 02), "compreendê-lo como novos meios de busca de financiamento público para determinados projetos. Mas não se baseia em 'dinheiro público', originários de governos, e sim dinheiro aplicado pelo próprio público". Disponível em: 〈http://abciber.org.br/simposio2011/anais/Trabalhos/artigos/Eixo\%206/17.E6/226-353-1-RV.pdf 〉
} 
comunicação que foi a ferramenta que tivemos que criar para dar visibilidade ao movimento porque não poderíamos depender dos grandes veículos. E agora um ciclo muito forte da questão econômica, de visualizarmos o processo do banco que a gente criou, da economia solidária, de como financiar essa história toda sem estar dependente de um mercado ou sistema político x ou y. (VILELA, 2013)

A rede Fora do Eixo desenvolveu um banco e uma moeda dentro da organização para realizar o financiamento de projetos culturais e também fornecer apoio a Mídia Ninja. Inicialmente, muitos ninjas moravam nas casas coletivas da rede e participavam do sistema de economia colaborativa. No entanto, após o programa Roda Viva, da TV Cultura de São Paulo, realizado em agosto de 2013, com os entrevistados e fundadores da Mídia Ninja, Bruno Torturra e Pablo Capilé, alguns ex-participantes do coletivo Fora do Eixo realizaram denúncias sobre o modelo de negócio da rede que também recaíram sobre a Mídia Ninja.

A cineasta Beatriz Seigner acusou o grupo FdE de promoção do trabalho escravo, uma "pós-escravidão" na qual os artistas e bandas envolvidos não recebiam nem a moeda do grupo, o Fora do Eixo Card, na época Cubo Card. De acordo com o post no Facebook da cineasta,

\begin{abstract}
Quem mora nas casas Fora do Eixo, abdica de salários por meses e anos, e, portanto, não tem um centavo ou fundo de garantia para sair da rede. Também não adquirem portfólio de produção, uma vez que não assinaram nada do que fizeram lá dentro nem fotos, nem cartazes, nem sites, nem textos, nem vídeos. E, portanto, acabam se submetendo àquela situação de escravidão (pós)moderna, simplesmente, pois não vêem como sobreviver da produção e circulação artística, fora da rede. Muitas destas pessoas são incentivadas pelo próprio Pablo Capilé a abandonar suas faculdades para se dedicarem integralmente ao Fora do Eixo. Quanto menos autonomia intelectual e financeira estas pessoas tiverem, melhor para ele. (SEIGNER, 2013).
\end{abstract}

O post se tornou viral e outros antigos participantes do FdE e da Mídia Ninja que saíram da rede relataram episódios nos quais não receberam pelo seu trabalho e foram explorados. A falta de transparência dos recursos adquiridos por meio de festivais, editais e outros eventos foi outro ponto destacado em diversos depoimentos. No entanto, Pablo Capilé, um dos fundadores do Fora do Eixo e os ninjas Bruno Torturra e Rafael Vilela defenderam, por meio de postagens no Facebook, o sistema de trabalho do FdE, colocando em pauta que existe muito além dessa discussão e que para aumentar o poder do jornalismo alternativo, tirar a assinatura de textos e imagens e ficar sem receber salários eram medidas necessárias para resistir sobre a mentalidade automática de produção cultural e midiática.

A Mídia Ninja nasceu inserida dentro de um contexto social e midiático no qual provocou mudanças e transformações. O jornalismo alternativo deixou de ser periférico para 
se tornar central. O centro das atenções, o centro das discussões. E desde 2013, a organização se propõe a cobrir manifestações, debater assuntos pouco divulgados na grande mídia e produzir em diversos formatos audiovisuais. De acordo com vídeo institucional ${ }^{29}$ da Mídia Ninja, nos últimos cinco anos foram mais de 7500 transmissões ao vivo, 100 mil fotos no banco de imagens, cerca de 4 mil horas de imagens filmadas e mais de 10 mil cartazes e memes.

A página do Facebook $^{30}$ da rede tem mais de 1,7 milhão de curtidas. O canal do Youtube da Mídia Ninja possui atualmente uma série produções, como: Delírios Utópicos de Cláudio Prado que possui vídeos com mais de 60 mil visualizações onde ocorre o debate de temas como uso da maconha, política brasileira, entre outros; Bernardo Fala com assuntos relacionados à gordofobia; Antônia Pellegrino com uma abordagem feminista para âmbitos políticos e sociais do país; documentários sobre assuntos pouco explorados no audiovisual brasileiro e as transmissões ao vivo, agora editadas, entre outros programas.

O financiamento da Ninja é realizado pela plataforma Catarse, site de crowdfunding, no qual 171 pessoas apoiam mensalmente o projeto com contribuições que podem variar de dez reais a 2 mil. Atualmente a Mídia arrecada um pouco mais de 6 mil reais mensais que representam $68 \%$ dos 10 mil que eles pretendem atingir, dados obtidos por meio do vídeo institucional.

A rede Fora do Eixo e a Mídia Ninja perceberam os erros iniciais da falta de transparência e produziram sites separados para dar maiores explicações sobre processos internos e fluxos organizacionais. O Portal da Transparência da Fora do Eixo ${ }^{31}$ é composto por histórico da organização, carta de princípios, prestação de contas com planilhas detalhadas referentes à distribuição da Fora do Eixo Card e aos financiamentos recebidos pelo coletivo. Há também no portal a página descrevendo os modos de organização da rede.

Atualmente, a Mídia Ninja mantém e alimenta um site para reunião dos artigos e vídeos produzidos por uma lista de novos colaboradores - que produzem textos, fotos e vídeos - denominada de Rede Ninja de Opinião ${ }^{32}$, que em 2018, fazem parte da lista nomes como: o do cantor Caetano Veloso, o do deputado Jean Wyllys, o do cantor Tico Santa Cruz, o da précandidata a vice-presidência e representante dos povos indígenas, Sonia Guajajara. Marielle Franco, vereadora da Câmara Legislativa do Rio de Janeiro, também era uma das

\footnotetext{
${ }^{29}$ Disponível em: < https://www.facebook.com/MidiaNINJA/videos/1040856756072469/ >

${ }^{30}$ Disponível em: $<$ https://www.facebook.com/MidiaNINJA/ >

${ }^{31}$ Disponível em: < http://foradoeixo.org.br/ >

${ }^{32}$ Lista completa de colaboradores da Mídia Ninja disponível em: 〈http://midianinja.org/>
} 
colaboradoras da rede. Ela produziu textos sobre a violência contra as mulheres, machismo, racismo e representatividade feminina na política. Assassinada no dia 14 de março de 2018, Marielle foi uma das vozes que, violentamente, tentaram calar, no entanto, sua voz se multiplicou e ganhou força em diversas outras durante as manifestações nas cidades brasileiras, nas quais a Mídia Ninja se fez presente. A representatividade e a pluralidade de discursos e parcialidades são os principais destaques da rede. 


\section{DA IMPRENSA DA INDEPENDËNCIA A ERA DA CONVERGÊNCIA JORNALÍSTICA}

\subsection{Contextualização histórica do jornalismo brasileiro}

A proposta desta pesquisa é analisar a cultura e os procedimentos organizacionais da Mídia Ninja. Para tanto, consideramos fundamental discutir os conceitos de jornalismo independente, jornalismo cidadão, newsmaking, cultura organizacional e clima organizacional. É essencial também uma breve contextualização histórica do jornalismo no Brasil para dar ainda mais base ao desenvolvimento da pesquisa, pontos que serão desenvolvidos ao longo dos próximos dois capítulos.

O jornalismo desde a invenção da imprensa de Gutemberg ${ }^{33}$, no século XV, adquiriu novos formatos e se expandiu. Mas foi durante o século XIX, de acordo com Rodrigo Carvalho da Silva (2012, p.02), que houve uma grande expansão do campo jornalístico por conta do processo de escolarização da sociedade, de urbanização e construção de grandes metrópoles, da liberdade conquistada por direitos fundamentais e da democracia como nova forma de governo.

No Brasil, houve quatro fases do jornalismo, de acordo com Juarez Bahia (2009) no livro História da Imprensa Brasileira. A fase inicial foi caracterizada pelo surgimento dos primeiros jornais do país, como a Gazeta do Rio de Janeiro, a partir de 1808, durante o reinado de D. João VI. De acordo com Bahia (2009, p.17) “O advento do jornalismo impresso se dá no momento de transição da colônia para sede do poder real". Humorismo, mordacidade e militância política eram três das principais características da imprensa da Independência.

A construção do perfil do jornalista e do seu papel dentro da sociedade foi iniciada durante essa primeira fase no Brasil, mas os debates começaram antes, na Europa. Tomando como ponto de partida a Revolução Francesa, muitos jornalistas sempre lutaram contra o cerceamento da liberdade de expressão. Liberdade, igualdade e fraternidade eram os princípios do movimento francês e se tornaram universais durante esse marco da passagem da cultura feudal para a contemporânea. Durante o século XVIII, a imprensa e os jornais que surgiram começaram a desempenhar um papel muito atuante na sociedade. O jornalista se comprometia com a busca pela verdade, eram "os cães de guarda da sociedade". Para

${ }^{33} \mathrm{O}$ alemão Johann Gutenberg, entre os anos de 1444 e 1456, século XV, inventou uma nova técnica: a máquina de impressão tipográfica, a imprensa mecânica de papel, que possibilitou a reprodução e divulgação de textos de forma rápida, barata e por meio de máquinas. De acordo com Jorge Pedro Souza (2008, p.70) "o aparecimento da tipografia de Gutenberg criou condições para a democratização da cultura." 
desenvolver o papel do jornalismo e do jornalista na sociedade, Bill Kovach e Tom Rosenstiel (2003, 22-23) elaboraram uma lista com nove itens fundamentais para o correto fazer jornalístico, que perpetuam até os dias de hoje:

1. A primeira obrigação do jornalismo é a verdade.

2. Sua primeira lealdade é com os cidadãos.

3. Sua essência é a disciplina da verificação.

4. Seus profissionais devem ser independentes dos acontecimentos e das pessoas sobre as que informam.

5. Deve servir como um vigilante independente do poder.

6. Deve outorgar um lugar de respeito às críticas públicas e ao compromisso.

7. Tem de se esforçar para transformar o importante em algo interessante e oportuno.

8. Deve acompanhar as notícias tanto de forma exaustiva como proporcionada.

9. Seus profissionais devem ter direito de exercer o que lhes diz a consciência. (KOVACH \& ROSENSTIEL, 2003, p. 22).

A segunda fase denominada fase da consolidação começa em 1880 e durante esse período ocorre a mudança da tipografia artesanal para à tipografia industrial. A sociedade já não é a mesma de 72 anos atrás, "é outro grau de consciência nacional, são outras as ideias que refletem", ideias essas abolicionistas, republicanas e liberais. E elas se refletem em diversas publicações e diários pelo país. Jornais como o Abolicionista de Joaquim Nabuco são lançados com pautas dedicadas à abolição da escravidão e ao debate contra o escravagismo. A caricatura repleta de crítica social ganha mais força durante a imprensa da Abolição e da República. Da mesma maneira que a cobertura internacional, devido à Primeira Guerra Mundial, ganhou espaço para o aumento das vendas dos jornais. Anúncios em cores, a máquina de escrever e os avanços da fotografia marcaram a época como as principais inovações na imprensa.

De acordo com Romancini e Lago (2007, p. 67), ao longo do período republicano, vários aspectos encaminharam ao fim da fase artesanal do jornalismo no Brasil. Em função dos custos elevados, a atividade da imprensa torna-se um empreendimento empresarial em sentido pleno, exigindo uma organização capitalista. $\mathrm{O}$ que encaminha a imprensa à terceira fase, a fase moderna, iniciada na década de 20 que tem como um dos principais pontos de início a primeira emissão de rádio em 1923. Há a consolidação da forma de produção industrial do jornalismo e os anunciantes se tornam a principal renda dos jornais ${ }^{34}$. Durante essa fase, alguns deveres e compromissos da imprensa, de acordo com Bahia, são

\footnotetext{
${ }^{34}$ Com o passar dos anos e com as diversas mudanças sociais, alguns veículos jornalísticos, aos poucos, foram perdendo o comprometimento social e entrando no âmbito comercial. Para conseguir acompanhar o capitalismo, os jornais tiveram que criar diferentes formas de arrecadação monetária e uma delas era a venda de ações das empresas ou utilização de anúncios.
} 
os de independência, apoiada em bases morais e econômicas suficientes para rejeitar a subvenção oficial; de imparcialidade, a partir da prática de dar espaço igual às partes em confronto, de acolher as diferentes versões de um fato e de evitar o alinhamento deliberado ou intencional; de honestidade, no sentido de dar voz às minorias, acolher contradições e expor claramente os fatos, de modo a que as notícias e os anúncios sejam transparentes, confiáveis; de exatidão, como complemento da imparcialidade e da objetividade, que resulta da necessidade de difundir a verdade apurada ou de precisar os fatos de tal maneira que cada um deles possa ser conferido pela sua veracidade; de critério, tendo em vista regras fundamentais de decência aplicáveis à linguagem, à ilustração, à busca e à publicação das notícias, de modo a imprimir discernimento e valor ao estilo; de responsabilidade, para que o jornalismo não seja apenas a enunciação do pensamento de seus proprietários, para que possa estabelecer padrões duradouros de identidade social, para que alcance na sociedade um conceito de instituição livre das injunções materiais dos seus mantenedores e seja capaz de, acima de quaisquer interesses, refletir o bem comum. (BAHIA, 2009, p. 223)

A televisão foi uma grande inovação e ganhou cada vez mais força durante a fase moderna do jornalismo. Cada inovação científica ou tecnológica inventada pelo homem ou cada transformação social ou transformação ideológica, no que concerne ao jornalismo, pode vir a gerar mudanças estruturais ou mudanças conjunturais, que podem afetar de diferentes maneiras a produção de conteúdo. O jornalismo vem sofrendo diferentes mudanças e crises. São avanços tecnológicos, técnicos e sociais que transformam o fazer jornalístico. Como desenvolvido por Fábio Pereira

Trabalhando diretamente com as transformações do jornalismo, Charron \& Bonville definem tais revoluções como momentos em que valores e práticas, tidos como essenciais ao exercício dessa atividade, passam por um momento de crise. Constatase, nesse caso, um nível elevado de incongruência entre diferentes categorias de objetivos e de regras pertinentes a um modelo. Ao mesmo tempo, verifica-se uma forte tensão cognitiva de um grupo considerável de jornalistas em torno dos elementos que estão em via de se transformarem. Do ponto de vista sociodiscursivo, os processos de revolução paradigmática envolvem alterações de tal amplitude que as regras associadas ao discurso jornalístico e o discurso em si não são reconhecíveis quando comparados ao paradigma anterior. (PEREIRA, F. 2011, p. 43)

No entanto, com a entrada da sociedade mundial na era contemporânea, o jornalismo foi se adaptando às diversas transformações culturais, sociais, processuais e ideológicas. Durante a Segunda Guerra, a profissionalização do mesmo caracterizou a imprensa como “quarto poder", junto com os outros três poderes, executivo, legislativo e judiciário, a imprensa tinha o papel atuante de fiscalizar a sociedade para torná-la cada vez mais democrática. Dessa forma, os jornalistas se tornaram gatekeepers, “indivíduo ou um grupo que tem o poder de decidir se deixa passar ou interrompe a informação" (WOLF, 2003, p.184). 
Em solo brasileiro, durante a quarta fase do jornalismo, de acordo com Bahia (2009, p. 413), a profissionalização da área acontece com a aprovação da Lei da Imprensa em 1969. Segundo Fábio Pereira, em uma matéria online, o jornalismo brasileiro seguiu para o lado estritamente informativo, tendo como pilar a objetividade, na qual "o repórter projeta a imagem de herói solitário, comprometido apenas com o interesse público e a transparência democrática" (PEREIRA, 2004). Com a primeira regulamentação realizada em 69, no ano de 1970 o diploma de jornalista foi definido como obrigatório para o exercício da profissão.

Dessa forma, estabelecendo um paralelo com o jornalismo atualmente e a história da imprensa brasileira comercial, que nos trouxe aos dias de hoje, é importante a afirmação do autor Nelson Werneck, na qual

\begin{abstract}
aquele que mais se destaca, ao nível dos fatos, é o que assinala a diferença, de qualidade e de função, entre a pequena e média empresa, que definiu o início da imprensa industrial, no Brasil, e a dimensão de grande empresa que define, hoje, um jornal ou mesmo, em menor escala, uma revista de grande circulação. Na proporção e no ritmo em que se desenvolvem as relações capitalistas aqui, desenvolveu-se a empresa jornalística. A oficina de um grande jornal moderno, no país, é inteiramente diferente do que era há meio século. A própria redação é diferente, avultando nela o papel daqueles que lidam com o aparelhamento técnico. (SODRÉ, 1999, p. 10).
\end{abstract}

Com análises sobre as redações dos jornais tradicionais e o estabelecimento da grande mídia, Sodré desenvolve uma narrativa completa sobre a história do jornalismo brasileiro até o ano de 1998, com uma abordagem inicial sobre a crise da área. É preciso realizar essa abordagem histórica, porque assim como afirmado por Ana Luiza Martins e Tânia de Luca, “a história do Brasil e a história da imprensa caminham juntas, se auto explicam, alimentamse reciprocamente, integrando-se num imenso painel. "' (MARTINS E DE LUCA, 2010, p. 08).

\title{
3.2 O jornalismo independente
}

Tendo esse breve aprofundamento histórico do jornalismo no Brasil, toma lugar a luz a origem da mídia alternativa, dos jornais independentes. $\mathrm{O}$ nascimento da imprensa alternativa durante a ditadura militar brasileira ${ }^{35}$ mostra como são conectados o surgimento de novos veículos de comunicação com as mudanças governamentais e sociais.

${ }^{35}$ A ditadura militar brasileira durou de 1964 a 1985. Teve início após o golpe de estado durante o mandato de João Goulart, no qual os militares instauraram um governo autoritário no país. Opositores ao regime foram duramente torturados e mortos, não existia liberdade de expressão, ocorreu a censura à imprensa e os direitos políticos da população foram cerceados. 
Em combate a censura e ao cerceamento da liberdade de expressão, o surgimento de um jornalismo alternativo durante a ditadura militar era inevitável para "transmitir informações que os grandes meios não queriam ou não podiam divulgar". (ROMANCINI \& LAGO, 2007, p.121). Periódicos como o Pasquim, Coojornal, Opinião ${ }^{36}$, Versus ${ }^{37}$ nasceram da luta dos jornalistas pela abordagem de um outro ponto de vista. Dando início aos primeiros exemplos de jornalismo independente.

Caracterizado pela Agência Pública ${ }^{38}$, jornal independente de São Paulo, em seu site ${ }^{39}$ como o jornalismo que surgiu em rede, fruto de projetos coletivos e não ligado a grandes grupos de mídia, políticos, organizações ou empresas, o jornalismo independente é um jornalismo livre das sanções sofridas por meio dos investidores, políticos e empresas que investem em um meio de comunicação. Esse tipo de jornalismo define um novo modelo de produção e edição, que durante a ditadura brasileira foi realizado em sua grande maioria por opositores ao regime ditatorial.

Enquanto a ditadura avançava e endurecia, com o surgimento de novos Atos Institucionais, a imprensa alternativa era bastante reprimida, o que contribuiu para que durante o início da abertura política ela não sobrevivesse. De acordo com o site Memórias da Ditadura,

com o recuo da ditadura, a anistia, a volta dos líderes da oposição que estavam exilados, as grandes greves de trabalhadores, a reorganização partidária, e a reanimação dos movimentos populares produziram uma rápida mudança no cenário político. A ampla frente pela democratização foi se desmanchando antes mesmo de alcançar plenamente seus objetivos, mérito da astúcia política da ditadura decadente, que conseguiu recuar em ordem, graças a medidas que promoveram a divisão da oposição. A nova conjuntura, com cada força política procurando ocupar seu espaço, já não demandava jornais generalistas, jornais de frente. Cada partido ou tendência tratava de produzir órgãos de comunicação de massas com suas próprias propostas. A consequência disso foi que, entre 1979 e 1981, a imensa maioria dos jornais da imprensa alternativa foi deixando de existir. A grande imprensa, que tratou de tomar suas bandeiras (e descaracterizá-las), logo recuperou sua hegemonia diante do público. Além disso, uma onda de atentados a bancas de jornal, na mesma época, amedrontou os jornaleiros que vendiam publicações de esquerda. (MEMÓRIAS DA DITADURA,

\footnotetext{
${ }^{36}$ Disponível em: 〈http://memorialdademocracia.com.br/card/opiniao-um-jornal-mutilado-pela-censura>

${ }^{37}$ Disponível em: < https://www.nexojornal.com.br/expresso/2018/05/03/A-import\%C3\%A2ncia-do-jornalVersus-publicado-durante-o-regime-militar $>$

${ }^{38}$ De acordo com o site, a Agência Pública "foi fundada em 2011 por repórteres mulheres, a Pública é a primeira agência de jornalismo investigativo sem fins lucrativos do Brasil. Com reportagens de fôlego, pautadas pelo interesse público, nossas matérias foram republicadas no ano passado por mais de 700 veículos de comunicação sob a licença Creative Commons. ” Disponível em: 〈 $\underline{\text { https://apublica.org/quem-somos/ }>~}$

${ }^{39}$ Disponível em: < https://apublica.org/mapa-do-jornalismo/\#_>
} 
Diferentemente de veículos que apoiavam a ditadura, como a Rede Globo que, segundo o mesmo site, citado anteriormente, Memórias da Ditadura ${ }^{40}$, foi "apoiada por capital dos EUA e por farta publicidade oficial, a emissora viria a ser a porta-voz oficial da ditadura", ela cresceu entre os anos de 1964 e 1985 e depois se manteve no topo. De acordo com Romancini e Lago,

o grupo Globo passou a contar com um know-how de gerenciamento e equipamentos que o diferenciaram das demais organizações de comunicação, o que facilitou a conquista da liderança no mercado de televisão. Como uma consequência, logo este veículo seria o meio preferencial para a divulgação do Brasil "grande" imaginado pelos militares (ROMANCINI E LAGO, 2007, p. 123).

Associando com a atualidade, a credibilidade dos grandes veículos de comunicação vem sendo questionada pela população brasileira. O discurso hegemônico de um grupo de famílias $^{41}$ - Marinho, Macedo, Saad, Abravanel, Frias e Mesquita, entre outras - que controlam toda a rede de comunicação do país, não representa grande parte dos brasileiros. A pesquisa Media Ownership Monitor Brasil ${ }^{42}$, realizada pelo coletivo Intervozes ${ }^{43}$ e Repórteres sem Fronteiras ${ }^{44}$ apresenta como um dos resultados que "os interesses dos grupos impedem a existência de uma pluralidade de vozes, o embate de opiniões e a coexistência de valores e visões de mundo diferentes. A mídia brasileira de maior audiência é controlada, dirigida e editada, em sua maior parte, por uma elite econômica formada por homens brancos. " De acordo com Romancini e Lago,

a sociedade não está livre do perigo de uma concentração de opiniões por parte dos meios de comunicação de massa. Cruzadas cívicas ou de qualquer outra natureza em períodos de crise institucional - como é o exemplo da história recente do Brasil - podem reunir numa só direção os propósitos e ataques dos principais veículos de modo a desequilibrar e perturbar as avaliações dos indivíduos. (ROMANCINI e LAGO, 2017, p. 269).

\footnotetext{
${ }^{40}$ Disponível em: < http://memoriasdaditadura.org.br/imprensa-alternativa/index.html >

${ }^{41}$ Lista completa das famílias disponível em: 〈 https://brazil.mom-rsf.org/br/proprietarios/pessoas/ >

42 De acordo com a pesquisa Media Ownership Monitor Brasil, há a distribuição de 50 canais de comunicação nas mãos de 26 grupos e todos possuem mais de um tipo de veículo de mídia. Disponível em: < https://brazil.mom-rsf.org/br/proprietarios/pessoas/ >

43 O Intervozes - Coletivo Brasil de Comunicação Social é uma organização que trabalha pela efetivação do direito humano à comunicação no Brasil. Para o Intervozes, o direito à comunicação é indissociável do pleno exercício da cidadania e da democracia: uma sociedade só pode ser chamada de democrática quando as diversas vozes, opiniões, culturas e raças que a compõem têm espaço para se manifestar.

${ }^{44}$ Repórteres sem Fronteiras é uma organização internacional que tem como objetivo defender e promover a liberdade de informação.Presente em mais de 150 países graças a uma rede de correspondentes locais, Repórteres sem Fronteiras luta diariamente e em todo o mundo por uma informação livre e independente.Reconhecida como associação de utilidade pública em França, RSF dispõe de um estatuto consultivo nas Nações Unidas e na Unesco e conta atualmente com dez sucursais espalhadas pelo mundo.
} 
O jornalismo das grandes empresas de comunicação brasileiras segue o Jornalismo de Combate, conceituado pelo autor Antônio Fausto Neto, como o jornalismo que "transforma o seu lugar de "elo de contato" entre instituições e sociedade em um outro, constituído por uma prática discursiva autoral. " (FAUSTO NETO, 2016, p. 66). Muitas vezes, essa prática discursiva autoral é utilizada para legitimar interesses da grande mídia e objetivos econômicos. Uma parcela do público, que é leitor e produtor de conteúdo, tem interesse em discussões qualificadas sobre questões sociais, profundidade na apuração e na abordagem das notícias. De acordo com Moraes (2007, p. 02) "as fronteiras entre quem emite e quem recebe podem tornar-se fluidas e instáveis. Os usuários têm a chance de atuar, simultaneamente, como produtores, emissores e receptores, dependendo de lastros culturais e habilidades técnicas". E a partir desses objetivos de discussões mais aprofundadas, surge a busca por um outro ponto de vista, por um outro jornalismo, o jornalismo independente.

A internet, possibilita então a origem de novos projetos e empresas de jornalismo independente, assim como desenvolvido por Moraes, "a comunicação virtual interfere então em direções conexas: jornalismo cooperativo e independente; denúncias da globalização capitalista e dos modelos de funcionamento da mídia tradicional; e discussão de propostas democratizadoras. " (MORAES, 2007, p.11). Caracterizado por Daniela Ramos no artigo Iniciativas do Jornalismo Independente Brasil e Argentina, as empresas desse tipo de jornalismo são

projetos inovadores, que atendam a demanda de um nicho de mercado, estabelecendo novos modelos de produção e distribuição, com gêneros alternativos de conteúdo, uma relação diferenciada entre produtores e público e, somado a tudo isto, um jornalismo auto sustentável, apartidário, que mantenha os parâmetros éticos e a preocupação em formar uma opinião pública esclarecida quanto aos direitos e deveres dos cidadão (RAMOS, 2015, p. 117)

Hoje, ano de 2018, o cenário é diferente. Diversas plataformas de jornalismo independente surgiram durante os anos de 2015, 2016, 2017 e continuam surgindo. Plataformas que procuram realizar um jornalismo mais bem apurado, mais detalhado. Um jornalismo que se importa com a experiência do usuário, com o design, com a tecnologia, já que sua principal renda é por meio das doações dos leitores. Estudos de ferramentas tecnológicas e digitais para monetizar interações online como likes e comentários vêm sendo realizados por esses jornais. A colaboração entre eles, diferente da disputa de público e de poder dos grandes veículos tradicionais é o que os fortalece. Juntos, criaram festivais de debate do jornalismo independente como Festival $3 \mathrm{i}$ - Jornalismo inovador, inspirador e 
independente ${ }^{45}$, pesquisas para implantação de novas tecnologias, matérias em conjunto, projetos para fortalecer o campo e a profissão de jornalista. A origem do jornalismo independente no Brasil, durante a ditadura, assim como no mundo, sempre associada a períodos de crise, de cerceamento de liberdade, faz com que o $\mathrm{BRIO}^{46}$, empresa de consultoria para jornalistas independentes, acredite que durante o ano de 2018, esse fazer jornalístico independente no Brasil se fortalecerá e crescerá ainda mais.

\begin{abstract}
Neste ano, teremos eleições presidenciais, e elas são o elemento mais importante do ano, é claro. Mas teremos também um ano de provação em relação às novas regras trabalhistas, um ano em que provavelmente o STF decidirá sobre a descriminalização do aborto, um ano em que a tendência é de mais crescimento da violência nas grandes cidades, um ano em que o avanço da agenda conservadora tende a ser dos mais relevantes das últimas décadas, um ano em que discursos de modelos econômicos bem-sucedidos ou fracassados se alternarão, cada um puxando a sardinha mais suculenta para o seu lado. Mas a carreira de jornalista seguirá gerando esperança. Prepare-se para ver florescer, neste ano, um jornalismo independente com cada vez mais qualidade e incorporando padrões de rigor técnico e tecnológico de alto nível, com referências não apenas na mídia brasileira, mas também em exemplos incríveis vindo dos Estados Unidos, Europa e América Latina. Nexo, JOTA, Agência Pública, Lupa, Aos Fatos, Ponte Jornalismo, Nova Escola, Poder360, nós mesmos aqui do BRIO, além dos players estrangeiros ancorados no Brasil, como El País, BBC, Buzzfeed e The Intercept. Em 2014, boa parte deles não existia. Os que existiam ainda não tinham encontrado sua maturidade. Mas mesmo os grandes veículos vão buscar fazer, em 2018, o melhor jornalismo possível. A sobrevivência deles depende disso, a exemplo da imprensa dos Estados Unidos, que, num momento de crise de confiança e com um presidente falando mal da mídia de manhã, tarde e noite, produziu em 2017 um jornalismo de alto nível e viu suas bases de assinantes (digitais) crescerem. A indústria jornalística no Brasil está sendo aspirada, e não tem muito outro jeito de escapar do tubo do aspirador a não ser fazendo jornalismo relevante e de impacto. (BRIO, 2018, p. 05).
\end{abstract}

\title{
3.3 Jornalismo cidadão
}

Com o processo de redemocratização do Brasil após a ditadura com a criação da constituição de $1988^{47}$ sendo o ponto de partida deste processo, a mídia se tornou o espaço

\footnotetext{
${ }^{45}$ A primeira edição ocorreu nos dias 11 e 12 de novembro de 2017 no Rio de Janeiro. Agência Pública, Nexo, Ponte, Lupa, Brio, Repórter Brasil, Nova Escola e Jota - se uniram ao Google News Lab para fazer um festival a fim de discutir questões que rondam quem está montando novas iniciativas jornalísticas.

${ }^{46}$ Brio surgiu inicialmente como um jornal independente focado na produção de grandes reportagens e que hoje atua no desenvolvimento de carreiras de jornalistas. É atualmente um Serviço de consultoria para capacitação e inserção de repórteres e outros profissionais de jornalismo para vagas de emprego e freelancer no mercado jornalístico. Disponível em: 〈https://briohunter.org/ >

47 De acordo com Alzira Abreu (2003, p. 29), "a elaboração e a promulgação da Constituição brasileira de 1988 se fizeram com a mobilização e a participação da sociedade civil, que enviou projetos e cartas abertas aos constituintes e fez pressão na fase de votação das emendas. Foram inscritos na Constituição os direitos civis tradicionais, de liberdade de pensamento e manifestação pública, assim como o direito à informação, à educação e à cultura, o direito do consumidor, o habeas-corpus, o mandado de injunção, o mandado de segurança coletiva,
} 
onde a população seria bem recebida com suas críticas e pautas. Com os direitos fundamentais garantidos por meio da constituição cidadã, o sistema judiciário falho e repleto de demandas não conseguia abarcar todas as necessidades dos indivíduos. A partir desse momento surgiu a preferência da população pela imprensa para ir em busca dos seus direitos, tornando o jornalismo uma "utilidade social" que, de acordo com Alzira Abreu,

identifica a ação jornalística como tendente a servir aos interesses concretos dos cidadãos e a responder às preocupações dos leitores ou da audiência referentes a emprego, habitação, educação, segurança, qualidade de vida etc. Esse seria o "jornalismo cidadão" (Watine, 1996). A imprensa assumiria aí o papel de mediadora e de interventora na sociedade (ABREU, 2003, p.30).

E após sete anos da criação da constituição de 88, a internet, que chegou ao Brasil em 1995, trouxe não só a possibilidade de conexão imediata com pessoas de diferentes regiões, mas a facilidade da propagação de um determinado conteúdo a custo zero, facilitando a publicação de matérias jornalísticas em blogs ou sites. Iniciou-se assim, a era do webjornalismo no Brasil. Alguns dos traços essenciais dessa era, citados por Maria das Graças Targino (2009, p.57), são "a interatividade, a hipertextualidade ${ }^{48}$, a convergência de mídias, o tratamento personalizado, a dinamicidade e a busca pelo lucro".

No entanto, a busca pelo lucro apontada inicialmente como uma das características do webjornalismo, atualmente vem se transformado na busca por justiça. O jornalismo não é mais realizado apenas por jornalistas, qualquer cidadão pode veicular seu conteúdo, sua produção, seu vídeo, realizar uma denúncia. O papel da profissão jornalística é colocado em prova, há o estabelecimento de uma crise de credibilidade e estrutural do antigo modo de realizar o jornalismo. A produção de conteúdo de fonte aberta ganha cada vez mais espaço na web, que agora "em lugar de anunciantes, voluntários; em lugar de empresários, pessoas comuns no gerenciamento de espaços virtuais; em lugar de discurso oficial, a voz das coletividades; em lugar de lucro (exorbitante ou não), justiça. ” (TARGINO, 2009, p. 59).

entre outros. No campo político, foi dado o direito de voto ao analfabeto e foi prevista a iniciativa popular legislativa. Pela primeira vez, uma constituição brasileira deu destaque aos direitos sociais, abrindo um capítulo de Declaração de Direitos. Além disso, foi aprovado e incluído na Constituição um Ministério Público independente de todos os poderes do Estado e com atribuições de representante da sociedade, com poderes inclusive para representar junto ao Judiciário interesses coletivos, difusos e individuais."

${ }^{48}$ De acordo com Targino (2009, p.55), "indo além de textos, inclui gráficos, sons, fotos, narração ou sequências animadas. Ambos, hipertexto e hipermídia, consistem em método não-linear de informações, permitindo ao indivíduo selecionar o material que vai ler/ver/ouvir, quando e como, ao tempo que estimula o aprofundamento de questões emergentes no decorrer da busca". 
Dessa forma, com o decorrer do tempo, jornais de grande circulação impressa, canais de televisão, revistas e rádios foram adaptando seus conteúdos para o meio online. Targino aponta

\begin{abstract}
o jornalismo como uma das profissões mais vulneráveis a tais mudanças, advindas, em grande escala, dos avanços científicos e tecnológicos. Como atividade do campo amplo da comunicação social, não se mantém a salvo das inovações tecnológicas. Ao contrário, webjornalismo e jornal digital conquistam cada vez mais espaço. Em linha similar, expande-se o jornalismo cidadão, a partir do propósito de facultar ao cidadão comum difundir suas matérias noticiosas, graças à filosofia de publicação aberta, que possibilita a veiculação de informações (TARGINO, 2009, p. 11).
\end{abstract}

Além do jornalismo independente, conceituado anteriormente, há a construção de um jornalismo contra-hegemônico, isto é "de questionamento do neoliberalismo e da ideologia mercantilista da globalização, bem como de denúncia de seus efeitos anti-sociais” (MORAES, 2007, p. 01). Um jornalismo que assim como o independente, busca apresentar outros lados além do da hegemonia dos grandes canais de comunicação brasileiros, é realizado não só por jornalistas e surge em momentos de cerceamento da liberdade de expressão. No entanto, é um jornalismo com posicionamento definido, sem a contemplação da imparcialidade, pregada como um dos princípios a serem seguidos pelos jornalistas. É um jornalismo que se mistura com movimentos sociais e acaba se transformando em um e que "defende a liberdade de expressão e os direitos da cidadania. " (MORAES, 2007, p. 01). De acordo com Abreu, o jornalismo cidadão

deve ser entendido como um dos meios de o jornalista, na atualidade, preencher um papel de ativista político caracterizado pela defesa de valores como rejeição à corrupção, defesa dos direitos dos cidadãos, igualdade no tratamento e na aplicação das leis etc. É importante assinalar que nossa pesquisa indicou que um número significativo de jornalistas que atuou na imprensa a partir dos anos 1950 tinha um engajamento político e que muitos escolheram a profissão corno uma forma de participação política e de intervenção na vida social. Desse modo, seria simplificador interpretar o jornalismo cidadão de uma perspectiva econômica. As preocupações mercantis não explicam ou não dão conta das motivações práticas dos jornalistas, particularmente sua visão de justiça. (ABREU, 2003, p. 38)

A Mídia Ninja tem como uma de suas principais vertentes o jornalismo cidadão. De acordo com Emir José Suaiden, então Diretor do Instituto Brasileiro de Informação em Ciência e Tecnologia, que estabelece uma conexão teórica com Targino, ele afirma que “jornalismo cidadão tem como propósito facultar ao cidadão comum difundir suas matérias 
noticiosas, graças à filosofia de publicação aberta, que possibilita a veiculação de informações no ciberespaço com a simples conexão de um computador à internet. ” (TARGINO, 2009, p. 12). Com mais de cinquenta correspondentes e colunistas espalhados em todo o Brasil, a Mídia Ninja representa diferentes grupos da sociedade que tem um local de fala e podem exercer o seu direito à liberdade de expressão no jornal.

Um dos pilares do jornalismo cidadão é o uso da internet para a consolidação da democracia, não tratando a notícia como um produto, como uma mercadoria, como o termo cunhado pela jornalista portuguesa Cremilda Medina "notícia, um produto à venda" como acontecia no jornalismo da fase industrial. A Mídia Ninja produz material jornalístico sem o intuito de lucro, mas com o objetivo de mostrar o que ocorre onde a grande mídia não está presente, não há ganho de dinheiro por meio das matérias, fotos e vídeos jornalísticos. De acordo com Targino,

\footnotetext{
Em se tratando da web social, a partir do momento em que há negociação, os valoresnotícias ressurgem dentro da lógica de mercado capitalista e ameaçam a filosofia central do funcionamento do jornalismo de fonte aberta, que se apoia a na colaboração e no compartilhamento dos recursos tecnológicos disponíveis, de forma igualitária e descentralizada, sem trâmites mercadológicos. (TARGINO, 2009, p.60)
}

\subsection{Newsmaking}

Como a presente pesquisa pretende entender a cultura organizacional e o clima organizacional da Mídia Ninja, o entendimento da teoria do newsmaking, do fazer jornalístico contribui para a compreensão e sistematização dos fluxos de produção da organização. Essa teoria pode ser entendida como a análise da produção da notícia e o entendimento dos fatores organizacionais e processuais que influenciaram na sua construção. Mauro Wolf (2003, p. 194) define dois pilares principais para a teoria "a cultura profissional dos jornalistas; a organização do trabalho e dos processos de produção. "

Dessa forma, existe a realização de uma metodologia para a fabricação das matérias que de acordo com Tuchman, (1977, p.45)

\footnotetext{
os aparatos de informação, com o objetivo de produzir notícias, devem satisfazer (entre outras coisas) três tarefas:

1. devem tornar possível o reconhecimento de um evento (inclusive dos excepcionais) como evento noticiável;

2. devem elaborar modos de relatar os eventos, que não levem em conta a pretensão de cada acontecimento de ser uma exposição idiossincrásica;
} 
3. devem organizar o trabalho temporal e espacialmente de maneira tal, que os eventos noticiáveis possam afluir e ser trabalhados de modo planificado. Essas tarefas estão inter-relacionadas. " (TUCHMAN, 1977, p.45)

E para estabelecer quais eventos são ou não noticiáveis, houve o mapeamento dos critérios de noticiabilidade já criados pelo jornalismo, que analisam a relevância do fato "do ponto de vista da estrutura do trabalho nos aparatos informativos e do ponto de vista do profissionalismo dos jornalistas" para "adquirir a existência pública de notícia" (WOLF, 2003, p. 195). Classificados em alguns grupos, os valores notícias podem ser relacionados ao conteúdo do fato, ao produto, ao meio, ao público e à concorrência. Novidade, brevidade e qualidade são alguns exemplos de critérios de noticiabilidade.

Sendo assim, cada veículo de comunicação desenvolve sua maneira de filtrar o que é ou não notícia, visto que, além da utilização dos valores notícia, "a relevância de um acontecimento é determinada e comensurada com base nas exigências organizacionais do aparato". (WOLF, 2003, p. 265).

Um outro ponto teórico abordado na pesquisa é a teoria da midiatização, de como os meios de comunicação influenciam o comportamento dos indivíduos e transformam rotinas de trabalho. É relevante o entendimento sobre a força que a mídia tem para promover transformações sociais. Stig Hjarvard enfatiza a

mídia como agente de mudança cultural e social. A midiatização é um processo de dupla face no qual a mídia se transformou em uma instituição semi-independente na sociedade à qual outras instituições têm que se adaptar. Ao mesmo tempo, a mídia se integrou às rotinas de outras instituições, como política, família, trabalho e religião [...] (HJARVARD, 2012).

Schulz Winfried (2004, p. 90) defende que a teoria da midiatização tem uma característica que impacta diversas organizações que é a fusão das atividades em um mesmo profissional. As redações jornalísticas atualmente têm um número menor de profissionais que se tornaram multitarefas, sendo essa uma das consequências do impacto dos meios de comunicação na vida cotidiana.

Dessa forma, ocorre o fenômeno da convergência, que segundo Henry Jenkins (2004, 2008), "a cultura contemporânea é em si a da convergência. Ela modifica as relações não apenas entre tecnologias existentes, mas entre indústrias, mercados, gêneros, audiências e consumo dos meios" (BARBOSA, 2013, p. 35). Essa convergência reflete no jornalismo. Jornalistas, atualmente, são capacitados para desenvolver trabalhos nas áreas de audiovisual, redação, fotografia, publicidade e se tornam o backpack journalist conceito elucidado e 
desenvolvido por Rich Gordon (2003) no artigo Implications of Convergence. De acordo com o autor, as tecnologias também estão se transformando e se tornando mais interativas, assim como as técnicas de storytelling ${ }^{49}$. Essas últimas vêm utilizando a transmídia, utilização de diferentes meios de comunicação para transmissão de uma mensagem complementar para dar ainda mais suporte para o entendimento do leitor.

A produção da notícia está intrinsecamente ligada a cultura organizacional e aos procedimentos internos de cada mídia. Entender os fluxos organizacionais de um veículo de comunicação é necessário para avaliar o jornalismo produzido pela mídia. O próximo capítulo propõe essa análise e entendimento dos conceitos de comunicação organizacional, tão intrínsecos ao newsmaking.

${ }^{49}$ De acordo com XX, "storytelling é a arte da tecelagem, da construção, o produto de um conhecimento íntimo. É um processo delicado, um processo que pode ser facilmente devastado, falhando com sua promessa, desintegrando em um simples texto. [...]. Boas histórias são valiosas, são dificilmente produzidas em massa. Professores, oradores e demagogos já reconheceram o seu valor - boas histórias entretêm, explicam, inspiram, educam e convencem. (GABRIEL, 2000, p. 01) 


\section{A COMUNICAÇÃO ORGANIZACIONAL DO JORNALISMO NÃO HEGEMÔNICO}

\subsection{Cultura e clima organizacional: conceitos, definições e conexões}

Entender a cultura organizacional da Mídia Ninja é o objetivo deste trabalho e para tanto, antes, é necessário definir o que é a cultura organizacional de uma empresa? Como ela se relaciona com clima organizacional? E com a comunicação organizacional? Essas são algumas das perguntas que guiam esse capítulo que é imprescindível para o entendimento do newsmaking do jornalismo móvel e ciberdigital realizado pelos ninjas.

Tendo sido estudada desde 1951, a definição de cultura organizacional foi sendo moldada por diversos pesquisadores e estudiosos durante os anos 1980. Em 1989, Ott (1989, p. 63) reuniu mais de setenta definições de cultura organizacional e de acordo com o mesmo pesquisador (apud MARCHIORI, 2009, p. 297), "a cultura é compartilhada, ressalta o comprometimento das pessoas com valores, tem sentido emocional, estabelece identificação dos membros e aprova ou não comportamentos".

Valores, crenças e comportamentos são três palavras-chave que permeiam a maioria das definições de cultura organizacional. Com a utilização desses conceitos, Brown (1998, p.7) afirma que "cultura organizacional refere-se ao padrão de crenças, valores e meios aprendidos de lidar com a experiência que tiveram, durante o curso da história de uma organização, e que tende a ser manifestada em seus arranjos materiais e no comportamento de seus membros."

Schein, além de definir cultura organizacional, traçou níveis da mesma e sua interação, pontos utilizados na metodologia de observação participante que serão abordados no próximo capítulo. Voltando ao conceito, Schein (apud FLEURY, 1987, p. 11) acredita que

Cultura organizacional de um grupo é um conjunto de pressupostos básicos (basic assumptions) que um determinado grupo inventou, descobriu ou desenvolveu ao aprender como lidar com os problemas de adaptação externa e integração interna, e que funcionam bem o suficiente para serem considerados válidos e ensinados a novos membros do grupo como a maneira correta de perceber, pensar e sentir, em relação a esses problemas. (FLEURY, 1987, p.11).

Marco Antônio Garcia Oliveira e Maria Ester de Freitas, ambos pesquisadores de cultura organizacional, elaboraram definições e conceitos para a área. Em um de seus artigos, Freitas desenvolve um conceito amplo e determinante para cultura organizacional, relacionando muitas vezes com a psicologia e a antropologia. 
Entendemos a cultura organizacional como um conjunto de representações imaginárias sociais, construídas e reconstruídas nas relações cotidianas dentro da organização, que são expressas em termos de valores, normas, significados e interpretações, visando a um sentido de direção e unidade, e colocando a organização como a fonte de identidade e de reconhecimento para seus membros. (FREITAS, 1996, p.294).

A autora defende que a construção da identidade do indivíduo, da busca por sentidos e significados estão atreladas à organização. A atmosfera do local de trabalho interfere na visão de cada um sobre a vida e sobre a sua própria identidade. A cultura organizacional é "um sistema que é ao mesmo tempo cultural, simbólico e imaginário. " (ENRIQUEZ, 1974, p.28). É imprescindível entender que a cultura organizacional é influenciada também por fatores externos, existe uma demanda da população, como citou Marco Oliveira,

o modo de gerir uma organização está intimamente ligada ao modo como o meio ambiente solicita essa organização. Existe assim, uma relação direta entre os problemas que o ambiente colocar para a organização e os procedimentos pelos quais esta tende a ser dirigida. (OLIVEIRA, 1988, p. 5).

E a construção dessa cultura organizacional, influenciada por fatores externos, pode ser explicada como "uma única identidade, por se tratar de uma só organização, mas é vista, vivida e praticada por indivíduos com percepções, visões e perspectivas distintas, que vão construindo seus significados e (res) significando-os em um ambiente cultural exposto às influências socioeconômicas e políticas. "(ALMEIDA, 2009, p. 217). Entender que os indivíduos são os que constituem e também os que constroem a cultura organizacional de uma organização, transforma o modo como ela é percebida. Não é possível analisar a cultura organizacional sem conhecer as pessoas que fazem parte da empresa. E como cada indivíduo é diferente do outro, a formação dessa cultura será sempre diversa, já que cada pessoa deixa a sua contribuição, uma influência do seu ser no espaço organizacional. Assim, cada cultura é diferente da outra, é única, "a cultura é para uma organização o que a personalidade é para um indivíduo. " (HARRISON; STOKES, 1992, p. 13).

A cultura e o clima organizacional, este último relacionado ao ambiente de trabalho e ao modo de como as pessoas se sentem trabalhando e convivendo dentro desse local, são elementos primordiais para a motivação dos funcionários, que, de acordo com o autor Prabhjot Kaur Mahsal, são a parte mais importante da empresa.

O clima organizacional tem um papel potencialmente rico, mas em grande parte não realizado no desenvolvimento de uma organização, bem como para aumentar a motivação dos funcionários. Os pesquisadores percebem problemas decorrentes de cultura significativa e clima diferente que afeta o nível gerencial e motivacional entre os funcionários. Em particular, os fatores de clima organizacional incluem ambiente, trabalho em equipe, efetividade da gestão, envolvimento, recompensa e 
reconhecimento, competência e compromisso. Estes fatores têm influenciado a motivação e visto como uma construção multidimensional. (MAHSAL, 2009, p. 17).

Esses elementos citados como fatores do clima organizacional, mostram a diferença entre clima e cultura organizacional. O primeiro estabelece uma relação de consequência ou reflexos da cultura da empresa. Como é o ambiente de trabalho, se o trabalho em equipe é fluido, são características vindas do ambiente cultural da organização. De acordo com Chiavenato

clima organizacional envolve uma visão mais ampla e flexível da influência ambiental sobre a motivação. É a qualidade ou propriedade do ambiente organizacional que é percebida ou experimentada pelos membros da organização e influência no seu comportamento. Refere-se ao ambiente interno existente entre as pessoas que convivem no meio organizacional e está relacionado com o grau de motivação de seus participantes. (CHIAVENATO, 2003, p. 45).

Já a cultura organizacional, como já mencionada, tem uma maior conexão com os valores e a construção da identidade da empresa, "é o reflexo da essência de uma organização" (MARCHIORI, 2009, p. 304) e como apresentada por Maria Tereza Fleury

a cultura é pensada como um sistema de representações simbólicas que expressam formas comuns de apreender o mundo, possibilitando a comunicação entre os membros de um grupo. Este conceito, a nosso ver, precisaria ser mais trabalhado em termos das múltiplas significações do universo simbólico e suas relações com outras instâncias da prática social, remetendo ainda às questões das relações de poder internas e externas às organizações. (FLEURY, 1987, p. 23).

Entender o conceito de cultura e clima organizacional são dois pontos de extrema importância no trabalho, que exercerão influências em todo o processo de pesquisa. Mas perceber também, a influência que a gestão exerce dentro desse clima coletivo é de grande relevância para a pesquisa. Entender como a organização é coordenada, como ocorre a divisão das tarefas, influencia o fluxo organizacional. A gestão interfere no clima e na cultura de uma empresa. $\mathrm{O}$ autor Jaime Crozatti acredita que

A cultura organizacional, entendida como o conjunto de crenças, valores e princípios partilhados pelas pessoas em uma organização, sofre interação direta do modelo de gestão em razão do poder exercido pelos principais gestores da organização na primeira. (CROZATTI, 1998).

A conexão dos dois conceitos, clima e cultura organizacional, com a comunicação é percebida como a última sendo elemento essencial para a existência dos mesmos. Entender que comunicação é a organização, é perceber que o clima e a cultura da empresa também são construídos e significados por meio da comunicação. De acordo com Marchiori (2009, p. 309), "a cultura deve ser continuamente construída por meio da comunicação, sendo as organizações sistemas de significados compartilhados em vários níveis. " A identidade da 
organização é formada pelos membros que se comunicam e estabelecem uma teia de significados comuns a todos que participam da empresa.

Entende-se identidade organizacional como o DNA da organização. Valores, objetivos, ideais, missão - o que a empresa faz e porque ela realiza essa função - e a visão onde a empresa pretende chegar, conquistas a serem alcançadas - são elementos que traduzem a essência de uma empresa, o significado dela. A identidade da organização pode ser percebida como

\begin{abstract}
o processo, atividade e acontecimento por meio dos quais a organização se torna específica na mente de seus integrantes (Scott e Lane, 2000). Esse processo compreende as crenças partilhadas pelos membros da organização sobre o que é central, o que a distingue e é duradouro RAC, Edição Especial 200361 A Identidade e o Contexto Organizacional: Perspectivas de Análise na organização (Albert e Whetten apud Whetten e Godfrey, 1998). Ele se constrói, dia após dia, quando o indivíduo vai internalizando a crença de que a organização na qual está inserido é a mesma que era ontem, simbolizando a sua existência temporal. Nessa perspectiva, Machado-da-Silva e Nogueira (2001), ao estudarem a identidade organizacional de duas organizações, procuraram destacar os seus aspectos distintos e duradouros, para interpretarem, a partir deles, as referidas identidades. Também Albert e Whetten (apud Whetten, 1998) ressaltam que a identidade organizacional tem três dimensões: (1) a definida pelos membros da organização, que é a central; (2) o que distingue a organização de outras; e (3) o que é percebido como traço contínuo, ligando o passado ao presente. (MACHADO, 2003, p.60).
\end{abstract}

A identificação entre os membros da empresa é muitas vezes influenciada pela identidade organizacional que é compartilhada pelos indivíduos. Para explicar esse tipo de identidade é preciso não só olhar para a organização como um todo, mas para as relações entre as pessoas, para o lado humano da empresa, para quem ela é.

A identidade organizacional, tal como as outras modalidades da identidade, remete ao vivido e à subjetividade. Ela orienta a ação dos indivíduos e é dinamicamente construída por meio de interações sociais, identificações e afiliações. Portanto o contexto identitário no âmbito organizacional é constituído pelo indivíduo, pelo grupo e pela organização. (MACHADO, 2003, p. 63)

A cultura, o clima e a identidade organizacional são elementos que tratam da subjetividade presente na organização, da comunicação interna, dos símbolos e imaginários compartilhados, dos sentimentos de cada membro da equipe. Entender que essa teia de ideias e elementos sofreu uma forte influência das novas tecnologias, alterando o modo como os fluxos organizacionais ocorrem é um dos pontos aprofundados a seguir.

\title{
4.2 O jornalismo da era do audiovisual
}


A era da internet, das redes sociais e das novas tecnologias vem transformando as relações sociais, econômicas e políticas. O comportamento dos indivíduos, das organizações é transformado por meio da comunicação online, que ocorre no "ciberespaço, onde a interação entre os mais diversos segmentos da sociedade está ocorrendo de uma forma horizontal e em múltiplos fluxos, havendo poucos obstáculos técnicos e sendo dispensada em muitos casos a existência de mediadores ou filtros. " (ALMEIDA; EVANGELISTA, 2013, p. 03).

A comunicação é uma das áreas que sofre mais interferências dos avanços da tecnologia, e é ela, que como já falado anteriormente, constrói a organização. Os usuários participam mais e são mais ativos, deixaram os perfis de apenas consumidores e leitores no passado e atuam como produtores e participantes críticos, o que foi facilitado por meio da utilização das novas tecnologias. De acordo com Almeida e Evangelista (2013, p. 04), “o jornalismo atual não se faz apenas para o público, se faz com o público."

Com o público e através das mídias comunicacionais, os midiativistas debatem por meio de outras narrativas o controle dos meios de comunicação concentrados nas mãos de poucos. Trazem perspectivas diferentes das que fazem parte do discurso hegemônico da grande mídia. Segundo Thiago Almeida (2014, p. 56), os midiativistas "proporcionam múltiplas visões, avaliações, enquadramentos e posicionamentos que nem sempre cabem nos modelos mercadológicos do mainstream midiático."

No âmbito do jornalismo, a democratização da comunicação é tema principal do midialivrismo movimento que defende a mídia livre, democrática, produzida por muitas vozes. Midialivrismo pode ser entendido como a busca por uma mídia livre, que não esteja concentrada na mão de poucos, mas sim distribuída nas mãos de muitos. Uma mídia horizontal, democrática e participativa. "Bandeira da mídia livre e de que todo cidadão é um potencial produtor de conteúdo" (PARENTE, 2014, p. 11). A liberdade de expressão e o direito à comunicação sendo exercidos por todos que quiserem exercê-la. De acordo com Fábio Malini (2013, p. 21) existem dois tipos de midialivrismo, o primeiro é o de massa que

reúne experiências de movimentos sociais organizados que produzem mídias comunitárias e populares, de dentro do paradigma da radiodifusão, se afirmando como práticas da sociedade civil alternativas e antagonistas em relação ao modo de se fazer comunicação dos conglomerados empresariais transnacionais e nacionais de mídia (MALINI, 2013, p. 21).

E o segundo é o ciberativismo, que

de uma forma não hierárquica, se utiliza de processos de colaboração social em rede e de tecnologias informáticas para construir dispositivos digitais, tecnologias e processos compartilhados de comunicação, cujo principal resultado é a produção de um mundo sem intermediários da cultura, baseada na produção livre e incessante do comum, sem quaisquer níveis de hierarquia que reproduza exclusivamente a 
dinâmica de comunicação um-todos (p. 21). Para o autor, o midialivrista é o "hacker das narrativas", um sujeito cujas narrativas são produzidas de forma dissonante dos ângulos, enquadramentos e visões da mídia corporativa. (ALMEIDA; EVANGELISTA, 2013, p. 6).

O ciberativismo, considerado pelos autores Malini e Antoun (2013, p. 19/20) "como sinônimo de ações coletivas coordenadas e mobilizadas coletivamente através da comunicação distribuída em rede interativa" nasceu dentro da cibercultura. Época esta caracterizada pelo aumento no número de blogs, sites, e atualmente, de $v \log s$ e canais na rede social de compartilhamento de vídeos o Youtube, que ganharam espaço entre os produsers ${ }^{50}$ nos últimos anos. Becker e Teixeira acreditam que

\begin{abstract}
A perspectiva do usuário como agente no processo de comunicação subverte a forma de distribuição unilateral e a recepção passiva de informações nas redes colaborativas, e aponta para uma nova maneira de pensar a relação entre produtores e consumidores, entre jornalistas e cidadãos, entre os veículos de comunicação e a sociedade (BECKER E TEIXEIRA, 2009, p. 48)
\end{abstract}

As conexões da cibercultura com a cultura hacker ${ }^{51}$, esta que muitas vezes para alcançar o objetivo de uma mídia livre e democrática, radicaliza o sistema, invertendo sua lógica para conquistar uma comunicação mais plural, são pontos importantes para o entendimento amplo dos movimentos que a Mídia Ninja está inserida. A cultura hacker, diferente do seu significado definido pelo senso comum, como invasão dos sistemas no meio online, atua de maneira independente das grandes empresas e nasce na rede e que tem como um dos principais ideais, a liberdade de informação. Segundo Sérgio da Silveira (2010, p. 07), "o movimento social inspirado pela contracultura, que pregava distribuir o poder e emancipar as pessoas pelo acesso às informações, tem nos hackers a sua principal representação.”

Um outro compromisso do movimento hacker, destacado por Silveira (2010, p. 07) é o compartilhamento de dados. A informação livre e disponível para todos que quiserem acessála e se utilizar da mesma. Dessa maneira, uma das características desse movimento é o movimento da fonte aberta - sem cobrança de direitos autorais por fotos, músicas, textos, vídeos - e software aberto - a não necessidade de pagamento na realização de serviços online, condutas presentes em mídias alternativas, inclusive na Mídia Ninja.

De acordo com Cecília Peruzo (2009, p.197), a mídia alternativa "reedita formas de expressão impressas e audiovisuais, cria novos canais e, ao mesmo tempo, se recria por meio

\footnotetext{
${ }^{50}$ De acordo com Bruns, uma combinação de producer (produtor) e user (usuário) para definir a parte ativa desta nova audiência engajada na criação colaborativa e autônoma (BRUNS, 2005, p.23).

51 Segundo Silveira (2010, p. 07) "Em geral, na matriz do pensamento hacker está enraizada a ideia de que as informações, inclusive o conhecimento, não devem ser propriedade de ninguém, e, mesmo se forem, a cópia de informações não agride ninguém dada a natureza intangível dos dados. 'A informação quer ser livre'. ”
} 
de novos formatos digitais que o avanço tecnológico favorece". Ângulos diferentes, enquadramentos inovadores e um acompanhamento e cobertura intensa dos fatos, são algumas das características das narrativas audiovisuais jornalísticas ${ }^{52}$ da Mídia Ninja, descrita por Vizeu,

A função da mídia de organizar e hierarquizar a realidade nos relatos dos acontecimentos ocorre de forma mais expressiva e impactante quando se faz uso da linguagem audiovisual, um campo da comunicação complexo na construção e ressignificação de sentidos (Vizeu, 2008, p. 7-14).

O processo de produção da notícia resulta da cultura profissional, dos processos produtivos, dos critérios de noticiabilidade e dos valores-notícia (Traquina, 2005). Além dos critérios e normas da área de Comunicação. A Mídia Ninja, mídia alternativa e independente, utiliza como principal linguagem, o audiovisual. Muitas vezes transmitindo ao vivo e sem cortes, ela produz a matéria jornalística seguindo a sua cultura organizacional e dos processos produtivos, as quais o presente trabalho busca descobrir como são. De acordo com Beatriz Becker e Juliana Teixeira $(2009$, p. 45) é preciso analisar "as novas tecnologias de informação para descentralização da produção jornalística, para a criação de novos formatos e conteúdos e, consequentemente, para a promoção de percepções mais amplas das realidades do Brasil e do mundo".

Sendo assim, a Mídia Ninja engloba todos esses conceitos analisados durante a segunda parte do capítulo. É uma rede midiativista, que atua por meio das mídias digitais e internet contra a hegemonia dos meios de comunicação brasileiro. Luta, por meio do ciberativismo, por causas como políticas, sociais, humanitárias e por uma mídia livre e democrática, ideais que fazem parte do midialivrismo. Se propõe a representar o maior número de vozes possíveis, por meio da ajuda de vários colaboradores e tem a cultura hacker como base da organização. A compreensão de todos esses aspectos permite o entendimento dos valores, da identidade da Ninja, o que facilita a obtenção de um maior conhecimento sobre a cultura organizacional da mídia, que é o objetivo da pesquisa.

\footnotetext{
52 De acordo com Becker e Teixeira (2009, p. 44), são práticas de jornalismo audiovisual, cuja qualidade pressupõe as representações dos fatos diversidade de atores sociais, pluralidade de interpretações, inovações estéticas e contextualização dos acontecimentos, o que o uso da convergência, necessariamente, não garante
} 


\section{METODOLOGIA}

Para coletar os dados sobre a cultura organizacional e procedimentos organizacionais da Mídia Ninja, a pesquisa é definida como quali-quantitativa, ou seja, há a utilização de métodos qualitativos e quantitativos para atingir os objetivos específicos. Os instrumentos de pesquisa inicialmente utilizados foram a pesquisa bibliográfica, "para estabelecer a base" (DUARTE, 2010, p. 245) na qual a pesquisadora avançou e questionários para entender mais sobre o clima organizacional da empresa antes da realização da imersão. Durante a segunda fase, a observação participante e a realização de entrevistas em profundidade guiaram a pesquisa para a análise dos processos de produção de conteúdo e da cultura organizacional.

Dessa forma, os questionários iniciais foram enviados aos trabalhadores das sedes de Brasília e Belo Horizonte da Mídia Ninja com 10 dias de antecedência à visita realizada pela pesquisadora nesses locais. Com o objetivo de caracterizar os fatores do clima organizacional, já estabelecendo uma primeira análise de como é o interior das casas coletivas do veículo de comunicação, os questionários serão como o primeiro olhar interno da organização.

Adotando os critérios utilizados no novo método de pesquisa de clima organizacional desenvolvido por Carlos Alberto Bispo (2006), os questionários serão divididos em dois principais eixos: fatores internos de influência e fatores externos de influência. Depois da aplicação e dos resultados, a análise e a interpretação dos problemas irão dar uma maior visibilidade ao interior da Mídia Ninja, atuando como um guia do que deve ser verificado e facilitando as próximas etapas da pesquisa.

De acordo com o autor, Mauro Wolf (2003, p. 191), "todas as pesquisas de newksmaking têm em comum a técnica da observação participante. "A observação participante vai seguir algumas recomendações de Marco A. Oliveira, no que concerne a análise da cultura organizacional

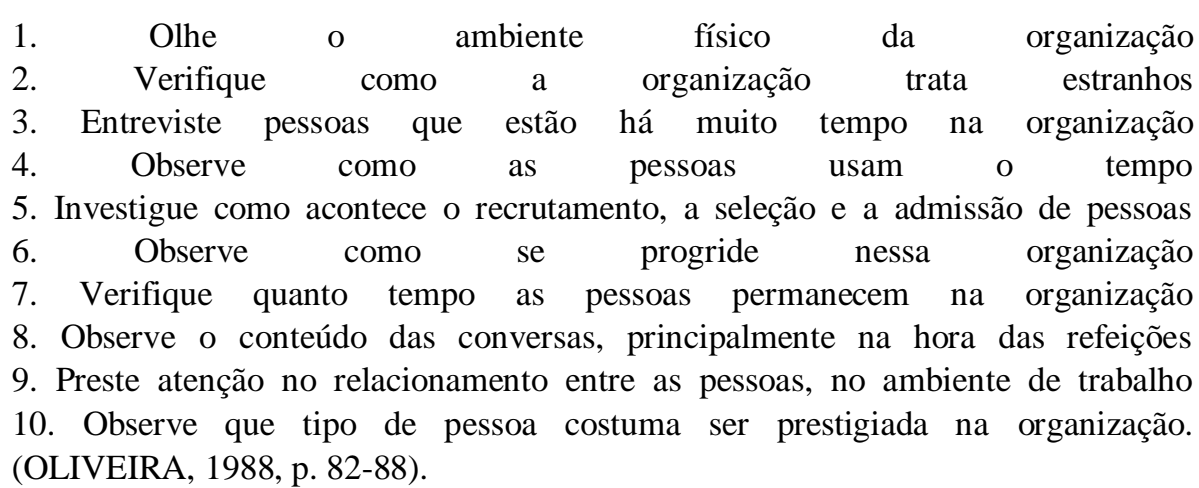


Além dessa análise profunda da cultura organizacional, houve também a investigação da produção jornalística, de como são os processos internos de escolha da pauta, de construção da notícia e da rotina jornalística. O registro dessas informações, obtidas através das entrevistas, foi feito por meio de gravador, com a permissão dos entrevistados e por meio de notas. Como definido por Christian Laville e Jean Dionne (1999, p.180-181), notas descritivas, analíticas, diário de bordo e notas de planejamento são essenciais para que a observação seja devidamente registrada.

Por fim, as entrevistas foram realizadas com jornalistas do time orgânico que moram nas casas coletivas, com os colaboradores e com os fundadores do grupo Mídia Ninja, que moram nas sedes de Brasília e de Belo Horizonte. Com o objetivo de uma maior análise da gestão influenciando a cultura, o clima e os processos organizacionais, os organizadores do projeto terão entrevistas nesse sentido. Diferentemente das dos jornalistas, as quais pretendem estabelecer um paralelo entre trabalhar em um jornal independente como a Mídia Ninja e trabalhar na mídia tradicional, traçando dificuldades, desafios e descobertas. O ponto em comum entre as duas entrevistas é a busca pela compreensão da comunicação organizacional do coletivo.

\subsection{Questionários}

A primeira etapa da pesquisa realizada com os trabalhadores da organização Mídia Ninja se deu com a utilização de questionários. Essa ferramenta metodológica quantitativa foi utilizada para dar uma visão inicial do funcionamento da empresa das perspectivas dos ninjas e quem são esses profissionais. Como o objeto de pesquisa é compreender a cultura organizacional da empresa, o público interno é de extrema importância para o entendimento dos fluxos comunicacionais e de trabalho. Aplicados de maneira online, construídos na plataforma de produção de questionários Google Forms, os questionários foram enviados para as duas sedes da Mídia Ninja, em Belo Horizonte e em Brasília com a antecedência de 20 dias antes do início da observação participativa.

O ponto principal no qual os questionários se basearam foi a Pirâmide de Maslow. Criada por Abraham H. Maslow, psicólogo norte-americano, a hierarquia das necessidades organizacionais defende que os indivíduos se esforçam para terem suas necessidades básicas e secundárias realizadas. De acordo com a pirâmide, existem as necessidades fisiológicas que são a base. Logo, há necessidades de segurança, depois as necessidades sociais, em seguida as necessidades de status ou estima e por último, a necessidade de auto-realização que ocupa o 
topo da pirâmide. De acordo com Maslow, cada ser-humano busca durante a vida conseguir atingir suas necessidades pessoais e profissionais e assim, chegar a auto-realização plena.

IMAGEM 1 - Pirâmide de Maslow

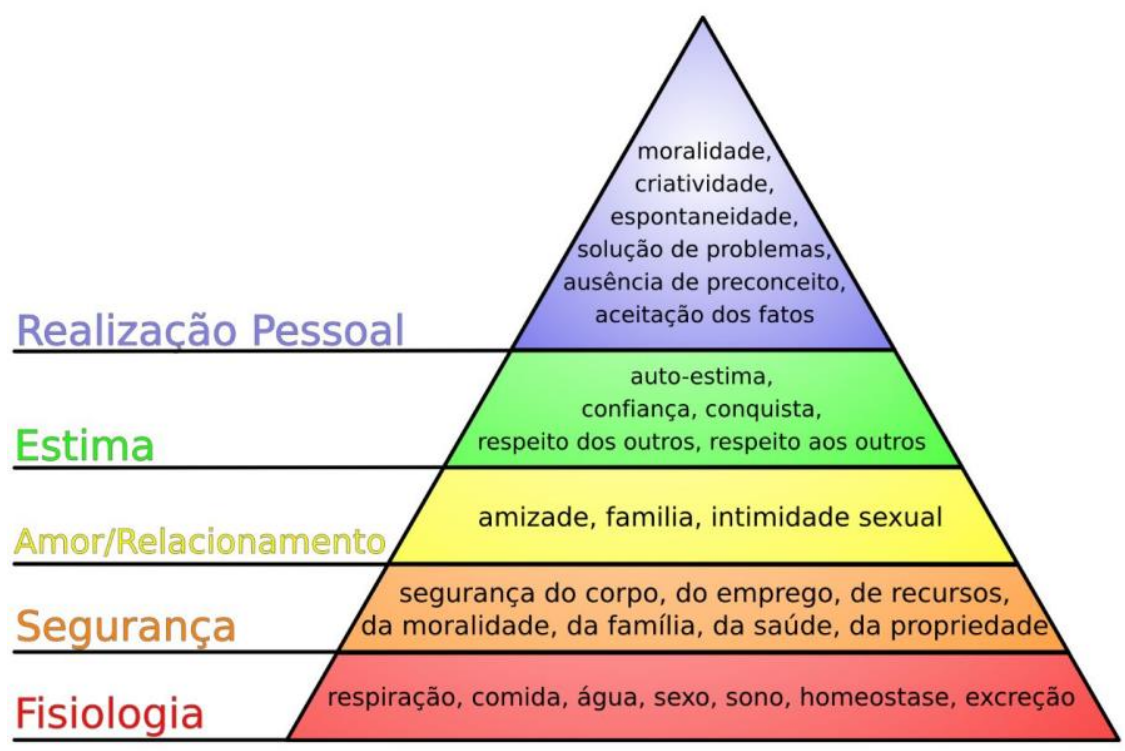

Fonte: Google imagens

Utilizada como ferramenta inicial para motivação de funcionários, a pirâmide serve na pesquisa como base para perguntas inaugurais sobre a cultura organizacional da Mídia Ninja. Entender se há um momento de descanso físico e mental (fisiologia), se existe segurança no trabalho (segurança), são alguns dos exemplos de questões realizadas inicialmente.

De acordo com Jorge Duarte (p. 67), o questionário é classificado como entrevista fechada, "realizada a partir de questionários estruturado, com perguntas iguais para todos os entrevistados, de modo que seja possível estabelecer a uniformidade e comparação entre as respostas". Tendo como principais objetivos traçar um perfil dos colaboradores da Mídia Ninja e de entender de forma introdutória para a pesquisa como é o funcionamento da empresa pelo olhar dos funcionários.

Alguns dos feedbacks recebidos durante a pesquisa sobre os questionários pelos respondentes foram que algumas perguntas continham palavras e expressões utilizadas no campo da Comunicação que poderiam ser explicadas nas questões. Outro ponto importante foi a pergunta sobre o grau de confiança no líder do grupo. Essa pergunta foi elaborada tendo como referência o líder como um editor-chefe de redação, como um chefe, que se encaixa em um sistema hierarquizado. Diferente da Mídia Ninja e do Fora do Eixo, no qual o líder é o 
líder de um movimento social, no qual as pessoas entram por estabeleceram uma relação de propósito de vida, e assim como descrito por um dos entrevistados, todos os ninjas poderiam responder que depositam um nível elevado de confiança no líder e alguns até poderiam se sentir ofendidos com a pergunta.

\subsection{Entrevistas de profundidade semi-abertas}

A realização de entrevistas de profundidade com colabores e viventes da Mídia Ninja teve como principal ponto de partida o resultado dos questionários já respondidos. Essa técnica qualitativa teve como objetivo responder as perguntas com maior número de respostas negativas ou confusas em relação a comunicação da organização ou de acordo com Margarida Kunsch "comunicação como organização, em vez da comunicação na organização" (KUNSCH, 2009, p. 74).

Um outro item que foi analisado durante as entrevistas é a relação entre os colegas de trabalho, algo que não poderia ser inteiramente percebido por meio dos questionários. De acordo com James Taylor "as relações ocorrem entre as pessoas com diferentes visões de mundo e que, para o sucesso da organização, sejam capazes de agregar accounts (experiências e perspectivas) ao account maior da organização (uma espécie de razão de ser). " (TAYLOR, 2005, p. 200). Entender como se dão as relações entre os colaboradores da Mídia Ninja é essencial para o entendimento da organização por si só.

Jorge Duarte em Métodos e Técnicas de Pesquisa em Comunicação, afirma que a entrevista em profundidade "procura intensidade nas respostas, não-quantificação ou representação estatística. [...]. Seu objetivo está relacionado ao fornecimento de elementos para a compreensão de uma situação ou estrutura de um problema. " Para entender como funciona a comunicação organizacional de uma empresa é preciso perguntar aos seus funcionários, aos colaboradores, as pessoas que passam parte do seu tempo dentro da empresa.

Classificadas como semi-abertas, as entrevistas seguiram um roteiro definido anteriormente com base em algumas perguntas do questionário respondidas pelos membros da Mídia Ninja e com base no problema de pesquisa definido que consiste em entender a cultura organizacional da organização. Dessa forma, foram utilizados dois roteiros de pesquisa, um destinado aos fundadores da Mídia Ninja e outro aos colaboradores e jornalistas da organização. 
$\mathrm{Na}$ entrevista semi-aberta aos fundadores, a utilização dos princípios da centralidade, da distintividade e da permanência definidos como centrais para entendimento da identidade de uma organização por Albert e Whetten (1985, p.264) as perguntas tiveram como foco a essência inicial da Mídia Ninja e as mudanças que ocorreram no decorrer do tempo. A percepção de como "éramos enquanto organização" e de como "somos como organização" é necessária para estabelecer uma comparação entre os valores que permaneceram e que ainda formam a cultura organizacional e a identidade da Mídia Ninja. "Podemos considerar identidade organizacional como o DNA da organização, os atributos que a definem, que a fazem ser diferente das demais e que, de certa forma, determinam o que ela será no futuro."

Já as entrevistas destinadas aos jornalistas e colaboradores da organização, a prioridade foi entender a identificação do ninja com a organização, os fluxos organizacionais do ambiente de trabalho, a rotina de produção, a estrutura organizacional e a motivação do funcionário. Com ponto de partida nesses cinco eixos centrais, foram desenvolvidas cinco perguntas com algumas sugestões que tinham como objetivo um maior detalhamento das respostas, o que contribuiu para o entendimento dos diferentes olhares dos trabalhadores sobre a cultura organizacional e sobre o clima organizacional da Mídia Ninja.

\subsection{Observação Participante}

Durante o período de sete dias, vivenciados na sede da Mídia Ninja em Brasília e em Belo Horizonte, houve a observação de diversos fatores dentro da organização por meio da técnica de observação participante. Essa metodologia "consiste na inserção do pesquisador do ambiente natural de ocorrência do fenômeno e de sua interação com a situação investigada", de acordo com Duarte (2010, p.70). Dessa maneira, a percepção da cultura organizacional pode ser vista de dentro por meio da presença constante do pesquisador, que de acordo com Marchiori (2009, p. 308), “observar a produção de cultura é perceber como as pessoas se relacionam (pensam, sentem e interpretam diferentes realidades) no interior de uma organização."

A comunicação expressiva, definida por Gaudêncio Torquato como "centrada nas capacidades e habilidades, nos comportamentos e na postura das fontes" (TORQUATO, 2009, p. 13), foi um dos pontos de partida para a análise do clima organizacional das casas Mídia Ninja. Como destacado pelo autor

Essa comunicação expressiva é a alavanca de mobilização interna, voltada que está para as operações rotineiras, bem como para a animação de ambientes internos. A 
comunicação se transforma em vitamina homeostática, promovendo o equilíbrio interno. O engajamento, a concordância e os níveis de motivação dependem desse sistema. Os fluxos de comunicação descendente e ascendente funcionam como veias abertas que fazem o sangue correr para os lados, para cima e para baixo. (TORQUATO, 2009, p. 13)

Um dos pontos que merece destaque durante a observação participante e fez-se presente no roteiro e guia desse tipo de estudo foi o feedback do líder para o jornalista. Como funciona, se é responsivo ou receptivo. De acordo com Redding (1972), a comunicação interna é extremamente importante, tanto que realizou dez postulados para o direcionamento dos estudos organizacionais, concentrando-se na comunicação organizacional sobre os receptores. O item 5 do postulado que diz "Importância do feedback nas organizações, com distinção entre o feedback receptivo e o responsivo" (KUNSCH, 2009, p. 67) foi inspiração para a análise do objeto durante a observação participativa.

A observação participante define o investigador como observador do ambiente. A pesquisa não deve ter a interação da pesquisadora como membro do grupo, mas como participante de todas as atividades, acompanhando e vivendo, no entanto, com o distanciamento necessário para entender por meio da observação a cultura e o clima organizacional da organização. No entanto, a antropóloga Favret-Saada (apud SIQUEIRA, 2005, p. 156) no texto Ser afetado, ela propõe a participação de fato, observando sempre todos os acontecimentos. Para o entendimento da situação é preciso estar realmente no lugar do outro, ter nossos afetos transformados e a partir disso conseguir entender. Desenvolver o afeto ao invés da empatia - desenvolvida durante a observação participante que cria uma distância que promove o entendimento do outro. Dessa forma, a proposta metodológica da autora é dividida em quatro fases: comunicação, explorar teoricamente a comunicação verbal e a não verbal; aceitar viver, viver o processo de disjunção e modificação da pesquisa por meio das experiências maleáveis e modificáveis; tempo de análise distante do momento da experiência, elaborar o texto em um período depois dos acontecimentos; levar em consideração a densidade particular de cada fato, muitas coisas que foram vividas são difíceis de relatar.

Adotando essa perspectiva de aproximação e de participação intensa, a metodologia da observação participante foi alterada pela pesquisadora. É importante ressaltar que essa metodologia teve como inspiração a observação participante e que por conta de circunstâncias apresentadas no próximo capítulo e por ser durante o semestre letivo, não pode ser realizada com a abordagem em profundidade necessária para o método, que solicita um maior tempo de 
observação. Dessa forma, para o entendimento do termo observação participante que aparece no decorrer da pesquisa, é preciso levar em conta esses aspectos.

As categorias de análise utilizadas para os dados obtidos por meio da observação participante para entender cultura organizacional foram: ambiente de trabalho, valores, estratégias, objetivos, desafios, processos estruturais visíveis, tecnologia, crenças estabelecidas, percepções, sentimentos. 


\section{A VIVÊNCIA NINJA}

\subsection{Descrição da aplicação da pesquisa}

A pesquisa teve como triangulação metodológica a aplicação de questionários, a realização de entrevistas em profundidade e a observação participante. De acordo com o planejamento inicial, os questionários seriam enviados duas semanas antes da realização da pesquisa de campo em si, nos locais de trabalho dos ninjas. No dia 02 de abril de 2018, os questionários foram enviados e as respostas eram esperadas até o dia 15 de abril, que seria o dia antes da primeira imersão na Mídia Ninja Brasília. O que não ocorreu.

Durante o mês de abril, escolhido para a aplicação da metodologia, o presidente Luiz Inácio Lula da Silva foi condenado por duas instâncias da Justiça referente ao caso do triplex no Guarujás ${ }^{53}$. A pena decretada foi de doze anos e um mês de prisão por acusações de corrupção e lavagem de dinheiro. De acordo com matéria da Carta Capital do dia 04 de maio de 2018,
a prisão do ex-presidente decorre de um procedimento manifestamente injusto, no qual foram violadas as regras de definição do juízo competente, o direito a um julgamento por magistrado imparcial, entre outros, sendo que o mais grave deles foi a ausência de provas que amparassem um juízo condenatório, conforme reconhecido pela maciça comunidade jurídica nacional. (CARTA CAPITAL, 2018)

A Mídia Ninja, com posicionamento definido de esquerda e que tem como um dos princípios a defesa da democracia, reuniu grande parte da equipe orgânica que estava nas casas coletivas Fora do Eixo de diversos estados para cobrirem o movimento Pró-Lula que se instaurou, inicialmente, em São Bernardo do Campo, região do ABC paulista, no estado de São Paulo. Com o objetivo de impedir a prisão do presidente Lula, os militantes se concentraram no Sindicato dos Metalúrgicos, onde o ex-presidente consagrou-se como líder sindical. Após a prisão do ex-presidente, os manifestantes foram para Curitiba, cidade sede da Operação Lava Jato, onde Lula foi preso e montaram o acampamento nas imediações da Superintendência da Polícia Federal, onde realizaram atos de apoio e solidariedade ao expresidente, nomeado de movimento "Vigília Lula Livre".

Os ninjas cobriram e acompanharam durante o mês de abril toda a movimentação e o processo de prisão do presidente Lula. As equipes da Mídia Ninja de Brasília, Belo Horizonte, Rio de Janeiro e São Paulo reduziram bastante em número, contando com no máximo, um ou dois jornalistas da equipe orgânica e alguns colaboradores. Dessa maneira, a pesquisa de

\footnotetext{
${ }^{53}$ Segundo matéria da Carta Capital, juiz Sérgio Moro decretou a prisão do ex-presidente Lula no dia 07 de abril
} de 2018. Disponível em: < https://www.cartacapital.com.br/revista/999/lula-preso-politico > 
campo, que iniciaria durante a terceira semana de abril, ficou impossibilitada, pois, de acordo com a foto abaixo, o único integrante presente da Mídia Ninja Brasília era Clayton Nobre, ninja e coordenador da Universidade Fora do Eixo em Brasília, um dos simulacros da organização FdE que por meio de oficinas e debates compartilha conhecimentos e retroalimenta a Mídia Ninja.

IMAGEM 2: Clayton Lopes, jornalista da Mídia Ninja no ambiente de trabalho, escritório do coletivo RUAS.

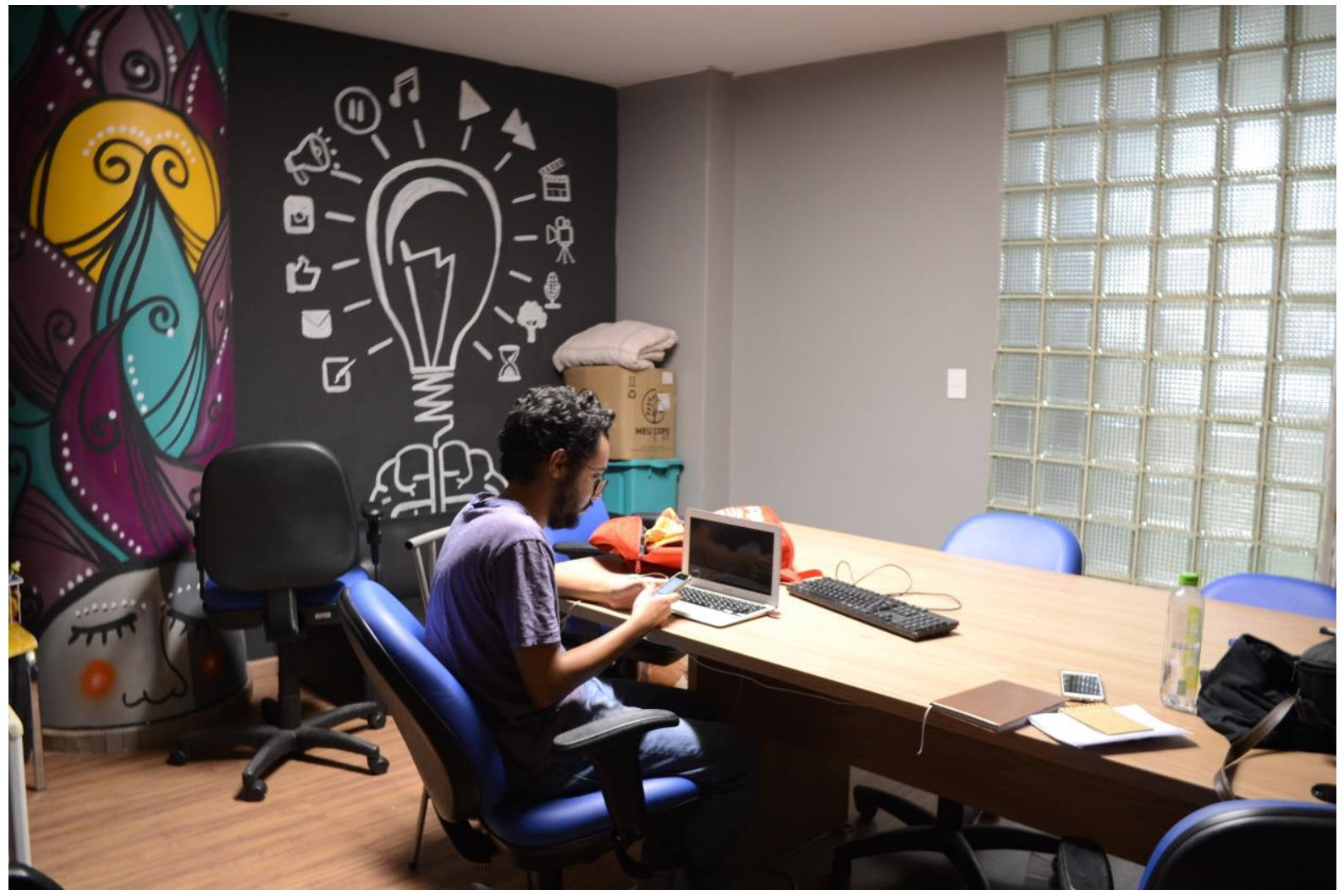

Foto: Fernanda Bastos

A primeira entrevista em profundidade foi realizada com esse membro da equipe orgânica no ambiente de trabalho dos ninjas em Brasília, que é o escritório da Rede Urbana de Ações Socioculturais, a RUAS. Esta oferece um espaço colaborativo localizado no Setor Bancário Sul, setor central de Brasília, utilizado como local de trabalho dos ninjas e colaboradores. A RUAS, Organização da Sociedade Civil de Interesse Público, OSCIP, acredita que

a mudança no meio social em que o jovem está inserido é possível somente a partir da ocupação dos espaços públicos para a prática de atividades saudáveis e lúdicas, das manifestações artísticas, da cultura urbana, música, dança, esportes, educação, comunicação comunitária, empreendedorismo social. Sendo os jovens o futuro do país, é fundamental pensar e discutir políticas públicas que assegurem direitos, 
atendam às necessidades, promovam possibilidades e ofereçam subsídios para a juventude se expressar, experimentar, aprender e desenvolver todo o potencial que possui. A R.U.A.S defende que a rua é, sim, um local de vivência, convivência e permanência saudável, por isso procura extrair o que de melhor e positivo ela tem a oferecer.A Rede respeita o jovem e o vê como um cidadão em formação que pode e deve emergir como agente de direito, forte, ativo, que precisa ser incluído no meio social. Não a partir de assistencialismo, somente, mas da equidade de gênero e de oportunidades, de liberdade, equilíbrio e justiça social. Partindo desta concepção e premissa, promove o empoderamento juvenil, unindo trabalho social de base e produção de eventos com foco na cultura urbana. (SITE JOVEM DE EXPRESSÃO, 2018)

Durante a quarta semana de abril, como elucidado por Clayton na entrevista realizada no dia 16 do mesmo mês, ocorreu o Acampamento Terra Livre, ao lado do Museu do Índio. O acampamento consiste na reunião de povos e lideranças indígenas no centro de Brasília em busca da defesa dos povos originários brasileiros. O encontro de 2018 com o tema "Unificar as lutas em defesa do Brasil Indígena - Pela garantia dos direitos originários dos nossos povos", ocorreu durante os dias 23 e 27 de abril. Com a cobertura coordenada pela Mídia Ninja, alguns dos colaboradores e membros da equipe orgânica que estavam em Curitiba voltaram ao Distrito Federal para auxiliar a produção das fotos e matérias. Realizada em parceria com órgãos como $\mathrm{APIB}^{54}$, INESC ${ }^{55}, \mathrm{CIMI}^{56}$ e Uma gota no oceano ${ }^{57}$, a cobertura colaborativa do Acampamento realizou uma reunião durante o domingo (22/04) que antecedeu a semana do evento para alinhamento da equipe.

\footnotetext{
${ }^{54}$ Criada em 2005, durante o Acampamento Terra Livre, a Articulação dos Povos Indígenas Brasileiros, APIB, de acordo com o site é "é uma instância de aglutinação e referência nacional do movimento indígena no Brasil, que nasceu com o propósito de: fortalecer a união dos povos indígenas, a articulação entre as diferentes regiões e organizações indígenas do país; unificar as lutas dos povos indígenas, a pauta de reivindicações e demandas e a política do movimento indígena; mobilizar os povos e organizações indígenas do país contra as ameaças e agressões aos direitos indígenas."

${ }^{5}$ De acordo com o site da instituição, "O Instituto de Estudos Socioeconômicos - INESC, criado em 1979, é uma organização não governamental, sem fins lucrativos, não partidária e com finalidade pública. A ação do INESC orienta-se para ampliar a participação social em espaços de deliberação de políticas públicas. Em suas intervenções sociais utiliza o instrumental orçamentário como eixo estruturante do fortalecimento e da promoção da cidadania. Para ampliar o impacto de suas ações, o INESC atua em estreita parceria com outras organizações, movimentos e coletivos sociais."

${ }^{56}$ CIMI - Conselho Indigenista Missionário "é um organismo vinculado à CNBB (Conferência Nacional dos Bispos do Brasil) que, em sua atuação missionária, conferiu um novo sentido ao trabalho da igreja católica junto aos povos indígenas." (Site do CIMI, 2018).

57 "Uma Gota no Oceano é uma organização sem fins lucrativos que trabalha em apoio a movimentos e organizações sociais, construindo estratégias de comunicação para ampliar a empatia e solidariedade ativa da sociedade brasileira com causas socioambientais. Identificamos oportunidades e estabelecemos pontes entre lideranças, organizações, formadores de opinião e a grande imprensa, ampliando a discussão de temas relevantes para a construção de um futuro mais consciente, justo e sustentável. Nossa principal ferramenta é a informação consistente e independente. Esta é nossa matéria-prima para apresentar novas abordagens, em diferentes perspectivas, gerando reflexão em relação às causas em que atuamos. ” (Site da Uma Gota no Oceano, 2018)
} 
IMAGEM 3: Reunião realizada para alinhamento da equipe do ATL.



Foto: Leonardo Milano

O acampamento, onde mais membros da Mídia Ninja estavam presentes, foi o primeiro momento da pesquisa de campo, utilizando a metodologia da observação participante. Esta não ocorreu dentro do ambiente de trabalho do coletivo, mas na tenda de comunicação do evento, na qual Clayton Nobre e Ísis Maria - ninja e coordenadora de redes sociais da Mídia Ninja - organizaram e distribuíram as pautas que precisavam de jornalistas e postaram os conteúdos obtidos através dos colabores nas redes sociais.

A observação participante da Mídia Ninja Brasília ocorreu durante a semana de 23 a 27 de abril, na qual ocorreu o Acampamento Terra Livre (ATL), o que configurou um desafio para a pesquisa, entender a cultura organizacional fora do ambiente de trabalho. Durante os três primeiros dias, houve o acompanhamento e descrição das atividades dos ninjas, a observação das conversas entre os colaboradores da Mídia Ninja, a compreensão do funcionamento do evento, todos esses fatos relatados no diário de campo da observação participante. Durante o quarto dia, a perspectiva de pesquisadora foi alterada para participante do coletivo, ser ninja durante um dia é, de acordo com Favret-Saada (apud MACHADO, 2014, p.4), afetar-se e auxilia o conhecimento sobre atuação dos membros da Mídia Ninja. A cobertura da marcha indígena que saiu do Acampamento e chegou a Esplanada dos Ministérios teve como uma das fotógrafas da equipe, a pesquisadora. Participar de fato, observando sempre, como proposto por Favret Saada (apud MACHADO, 2014, p.3) foi de extrema importância para a pesquisa. Entender por um dia o que é ser ninja teve como principal contribuição a possibilidade da transmissão de parte da cultura e identidade organizacional da Mídia Ninja para a pesquisa. 
IMAGEM 4: marcha indígena em direção ao Congresso Nacional realizada no ATL 2018.

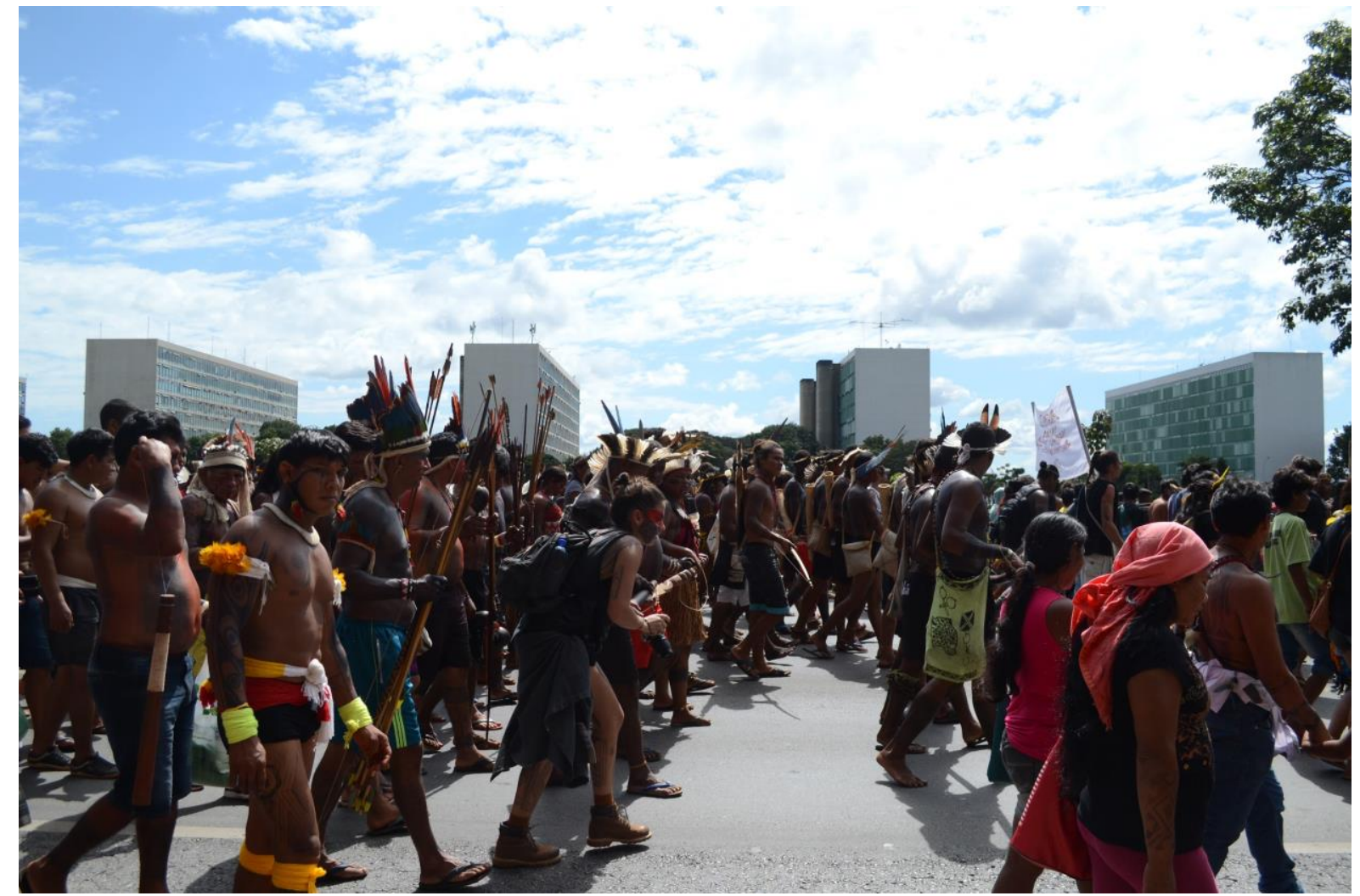

Foto: Fernanda Bastos

Durante a semana do ATL, não foi possível a realização de entrevistas, pois a quantidade de pautas como audiências discutindo as ameaças aos direitos dos povos indígenas no Senado Federal e Câmara dos Deputados, além de eventos como apresentações dos povos e shows de artistas que abraçam a causa dentro do acampamento deixaram a equipe de comunicação bastante ocupada. Dessa maneira, as entrevistas em profundidade foram realizadas nas semanas seguintes, com os membros da equipe da Mídia Ninja que ficaram no Distrito Federal e não voltaram para Curitiba para continuar a cobertura do Acampamento pró-Lula. Os outros dois entrevistados foram Louise Akemi, ninja e coordenadora de logística e dos recursos - financeiros e não financeiros - do Fora do Eixo e Gustavo Santos, colaborador da Mídia Ninja e foram entrevistados no Taguatinga Shopping, centro comercial localizado em Taguatinga e em Ceilândia, na sede do projeto Jovem de Expressão ${ }^{58}$, respectivamente.

\footnotetext{
58 Segundo o site do projeto o Jovem de Expressão "foi criado em 2007, a partir de uma pesquisa que demonstrou como a violência afeta a juventude. Sua tecnologia social uniu a promoção da saúde ao potencial criativo de jovens entre 18 e 29 anos e sua capacidade única de gerar respostas. O programa trabalha para evidenciar a inteligência advinda dos movimentos culturais da juventude e suas formas de convivências e transformações no mundo contemporâneo. As expressões culturais e de identidades são fundamentais para entender o papel da juventude nas transformações de consumo, produção e de novos arranjos produtivos. Dessa
} 
Por meio do email, a entrevista de Cláudia Schulz, uma das fundadoras e integrante da equipe orgânica de São Paulo, foi recebida no dia 18 de maio.

Após a realização de entrevistas com os membros da Mídia Ninja que estavam no Distrito Federal, houve a viagem para Belo Horizonte no dia 24 de maio, para entender se existiam diferenças de uma cultura organizacional em uma sede para outra e perceber como é trabalhar na casa Mídia Ninja Minas. Diferentemente de Brasília, os ninjas da capital de Minas Gerais trabalham em tempo integral no mesmo local onde moram, sem um outro local de trabalho coletivo, como o escritório do RUAS, na capital do Brasil.

O primeiro dia de pesquisa em Belo Horizonte (24/05), ocorreu de maneira semelhante ao penúltimo dia da cobertura do ATL. A pesquisadora entrevistou Thanee Degasperi, integrante da equipe orgânica da Mídia Ninja e depois da realização da entrevista participou ativamente da produção da matéria, fotografando alguns momentos da Conferência Nacional Popular de Educação, Conape, a qual reuniu centenas de educadores, professores, alunos, universitários do país inteiro nas ruas de Belo Horizonte para manifestar contra o desmonte da educação pública e do corte de gastos públicos.

forma nosso papel é criar espaços, facilitar a colaboração e apoiar a geração de autonomia entre os jovens. " (SITE JOVEM DE EXPRESSÃO, 2018) 
IMAGEM 5: Marcha da Conape no centro de Belo Horizonte.

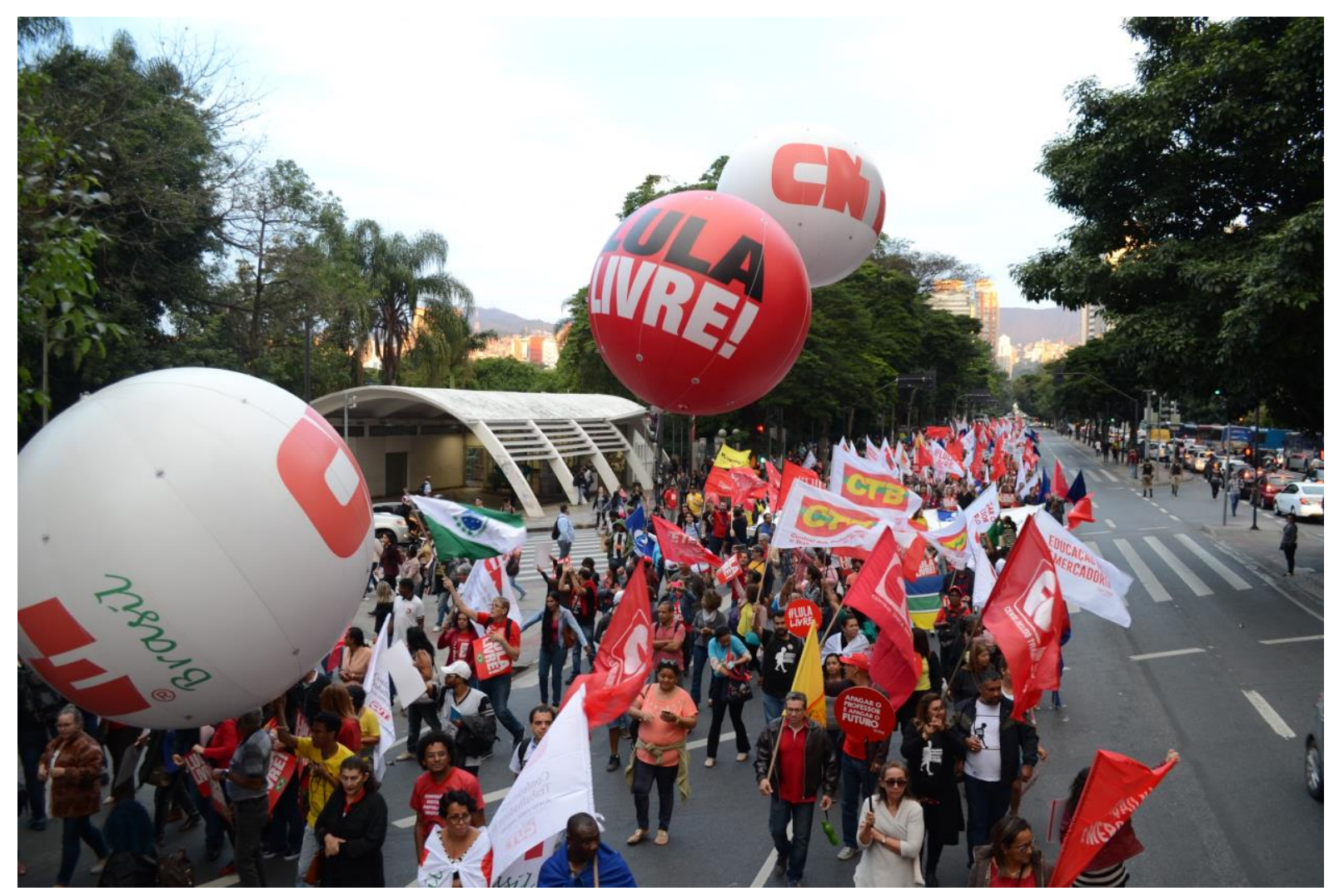

Foto: Fernanda Bastos

No segundo dia de pesquisa (25/05), houve a visita à casa da Mídia Ninja. Durante a tarde, ocorreu a observação participante do local onde os ninjas vivem e trabalham. Foram entrevistados também Isis Maria que trabalha na Mídia Ninja Brasília, mas que durante aquela semana estava em Belo Horizonte para organizar um projeto. Thalles Lopes, um dos líderes da casa da Mídia Ninja Minas foi entrevistado também durante a tarde do dia 25. No entanto, durante essa semana ocorreu a greve dos caminhoneiros ${ }^{59}$ o que afetou o trabalho dos ninjas que estavam na capital de Minas e o que estavam no interior, realizando o Minas Lab, "projeto de incubadora de novas mídias para a juventude" (NINJA, 2018). Segundo o site da Mídia Ninja, o projeto consiste na "construção de uma nova rede de mídia cidadã em Minas Gerais. 16 cidades do interior do estado irão receber 4 oficinas, sendo elas voltadas para fotografia, audiovisual, redes sociais e redação. Ao fim das oficinas a intenção é que os participantes possam criar um núcleo de mídia local que irá produzir conteúdo sobre sua

\footnotetext{
${ }^{59}$ Categoria de caminhoneiros paralisou as atividades no dia 02 de junho de 2018. Iniciada por motoristas autônomos, a mobilização também teve o apoio das transportadoras. Bloquearam estradas e pararam a distribuição de produtos durante uma semana. A principal reivindicação era da retirada de encargos tributários que incidem sobre o diesel para baixar o preço. além da revisão da política de preços adotada pela Petrobrás a partir de 2016, após Temer assumir a presidência.
} 
realidade e usar o midialivrismo como instrumento para causas sociais e culturais". (NINJA, 2018)

Durante a segunda semana de pesquisa, três ninjas foram para o interior para realizar as oficinas do Minas Lab. Dessa maneira, durante a semana dos dias 28 de maio a $1^{\circ}$ de junho, a casa ficou somente com um integrante.

Ao final da pesquisa, houve a realização de sete entrevistas, entre elas, um colaborador, quatro integrantes da equipe orgânica que são jornalistas e dois fundadores; houve nove respostas no questionário e foram dois locais em um curto período de tempo de realização da observação participante.

IMAGEM 6: Resumo das atividades da pesquisa de campo

\begin{tabular}{|c|c|}
\hline Atividade & Data de realização \\
\hline Entrevista Clayton Nobre & $16 / 04$ \\
\hline $\begin{array}{c}\text { Acompanhamento da reunião sobre } \\
\text { cobertura do ATL }\end{array}$ & $22 / 04$ \\
\hline Observação participante durante o ATL & $23 / 04$ a $27 / 04$ \\
\hline Entrevista Louise Akemi & $03 / 05$ \\
\hline Entrevista Gustavo Santos & $10 / 05$ \\
\hline $\begin{array}{c}\text { Recebimento da entrevista Cláudia Schulz } \\
\text { Observação participante da Conape e } \\
\text { entrevista Thanee Degasperi }\end{array}$ & $18 / 05$ \\
\hline $\begin{array}{c}\text { Entrevista Isis Maria e Thalles Lopes e } \\
\text { observação participante da casa Mídia Ninja } \\
\text { Minas }\end{array}$ & $24 / 05$ \\
\hline
\end{tabular}

Fonte: Fernanda Bastos

\subsection{Análise do público interno da Mídia Ninja}

Utilizando os questionários como principal ferramenta para estabelecimento do perfil do público interno da Mídia Ninja, as nove respostas obtidas do instrumento de pesquisa utilizada, três de colaboradores e seis de membros da equipe orgânica puderam estabelecer uma amostra dos integrantes da organização com maior ênfase em Brasília e Belo Horizonte. Amostra essa com representatividade de 9 membros de uma equipe de 12 integrantes dividida 
entre os dois locais de pesquisa. A primeira fase do questionário teve como principal objetivo entender quem são os participantes da Mídia Ninja, dessa forma, perguntas como faixa etária, gênero, formação escolar, entre outras foram utilizadas para delimitar o público interno. Uma observação importante é que o questionário não foi aplicado para fundadores, somente membros da equipe orgânica e colaboradores por ter em sua constituição questões relacionadas ao funcionamento das lideranças e aos fundadores, e no caso, os mesmos não tem líderes, pois eles desempenham essa função. Dessa maneira, durante esse subcapítulo analisaremos as respostas dos membros.

$\mathrm{Na}$ pergunta referente a faixa etária, a maioria da amostra, quatro de nove respostas, foram entre 30 e 35 anos. Duas pessoas responderam ter entre 26 e 30 anos e outras duas afirmaram ter entre 20 e 25 anos. Apenas uma pessoa respondeu ter mais de 36 anos. A maioria do público interno da Mídia Ninja Brasília e Belo Horizonte é formada por jovens abaixo de 35 anos.

Cinco das nove respostas relacionadas à identificação de gênero foram feminino, mulheres. Quatro respostas foram masculino, homens. Na entrevista de Ísis Maria, uma das coordenadoras das redes sociais da Mídia Ninja que trabalha na sede de Brasília, ela destaca como uma das principais diferenças entre as duas casas a predominância de mulheres na casa Brasília.

Em relação ao local de nascimento, a maioria dos respondentes (quatro) nasceu no estado de São Paulo, um declarou que nasceu no Amazonas, um outro membro nasceu no Distrito Federal, um outro nasceu em Goiás, um outro Mato Grosso e um outro Rio Grande do Sul. As duas casas possuem membros e colaboradores de diferentes regiões do Brasil, o que é um fator que influencia na convivência dentro das casas e foi destacado em várias entrevistas como sendo a diversidade um ponto extremamente positivo para a cultura organizacional e a produção de conteúdo.

Da mesma forma, as raças e etnias com as quais os integrantes da Mídia Ninja se identificam contribuem para a rede. A maioria dos respondentes (quatro) se identifica com a raça branca. Três pessoas declararam se identificaram com a raça negra. Um outro respondente se identifica com a raça amarela e um outro respondente, preencheu a categoria outros, com a etnia afroindígena, se declarando em caso étnico, mas não em raça.

A maioria dos respondentes (oito) declararam ser solteiros como estado civil e apenas uma pessoa declarou o estado civil como divorciada. Ter ou não um companheiro (a) e ter ou não filhos são fatores que influenciam no convívio dentro das casas, pois, de acordo com 
alguns entrevistados, as crianças e as famílias residem também no espaço coletivo que são as sedes da Mídia Ninja. A maioria dos respondentes (sete) declararam não ter filhos, no entanto, dois dos respondentes tem filhos.

Em relação ao nível de escolaridade, a maioria dos respondentes (quatro) afirmou estar cursando o ensino superior. Dois membros concluíram o ensino superior e outros dois respondentes concluíram o mestrado. Um membro declarou ter ensino médio completo. No que se refere às áreas dos cursos realizados pelos membros, a maioria (três) realizou comunicação, entre eles, um no campo de Comunicação Organizacional e outro no de Relações Públicas. Um dos respondentes é da área de Biologia, um outro é do campo da História, mas não pretende concluir o curso, um outro membro é das artes cênicas, um outro cursou ou cursa relações internacionais e um outro respondente afirma estudar Teoria Crítica e História da Arte. A maioria dos respondentes (sete) é da área de humanas.

A maioria dos respondentes (seis) trabalha na sede do Distrito Federal, dois outros respondentes afirmaram trabalhar em São Paulo e apenas um trabalha em Belo Horizonte. Em relação ao morar na casa coletiva, a maioria dos respondentes (seis) afirmaram ser parte da equipe orgânica e viver na casa Mídia Ninja, outros três respondentes declararam não morar na casa e fazem parte da equipe de colaboradores.

\subsection{Análise do ambiente interno}

Na Mídia Ninja Brasília, o escritório da RUAS, já citado anteriormente, é o local onde os integrantes da equipe orgânica se reúnem com os colaboradores. Localizado no Setor Bancário Sul, área central da capital do país, ao lado da rodoviária e de fácil acesso, o ambiente transforma-se em base durante os dias de cobertura intensa em eventos que ocorrem na Esplanada dos Ministérios, na Asa Sul ou Asa Norte. O prédio localiza-se à 5 minutos andando da estação do metrô Galeria e 10 minutos de distância da rodoviária de Brasília.

Algumas das percepções, obtidas através da observação participante, do espaço onde ocorrem as reuniões são a ocupação de outros coletivos, como o RUAS, o Bambuo, coletivo que provê a comunicação para ONGs e projetos socias, que realizam encontros no mesmo local. Existem três salas no espaço, uma é a sala de reuniões, outra é a sala dos computadores e a outra é a sala com mesas e com uma cafeteira. A sala mais utilizada pela Mídia Ninja é a sala de reuniões. Nesse local há um grafite colorido e estilizado na parede lateral e um outro grafite de cor branca com o desenho de uma lâmpada e símbolos criativos em volta, uma parede metade em ladrilhos de vidro e a outra metade cinza, a outra parede com uma tela de 
televisão para apresentações e a última parede toda em vidro com a vista para a cidade de Brasília. Há uma mesa ao centro com cadeiras acolchoadas azuis ao redor, um sofá preto, uma cadeira de praia, uma mesa de escrivaninha, um frigobar, alguns ventiladores e uma extensão de tomadas de papelão. O local não é desorganizado, há alguns adesivos coloridos colados na janela e algumas caixas de papelão nos cantos o que não polui visualmente o ambiente e não atrapalha a circulação de pessoas dentro da sala.

IMAGEM 7: Escritório do RUAS, ambiente de trabalho da Mídia Ninja Brasília.

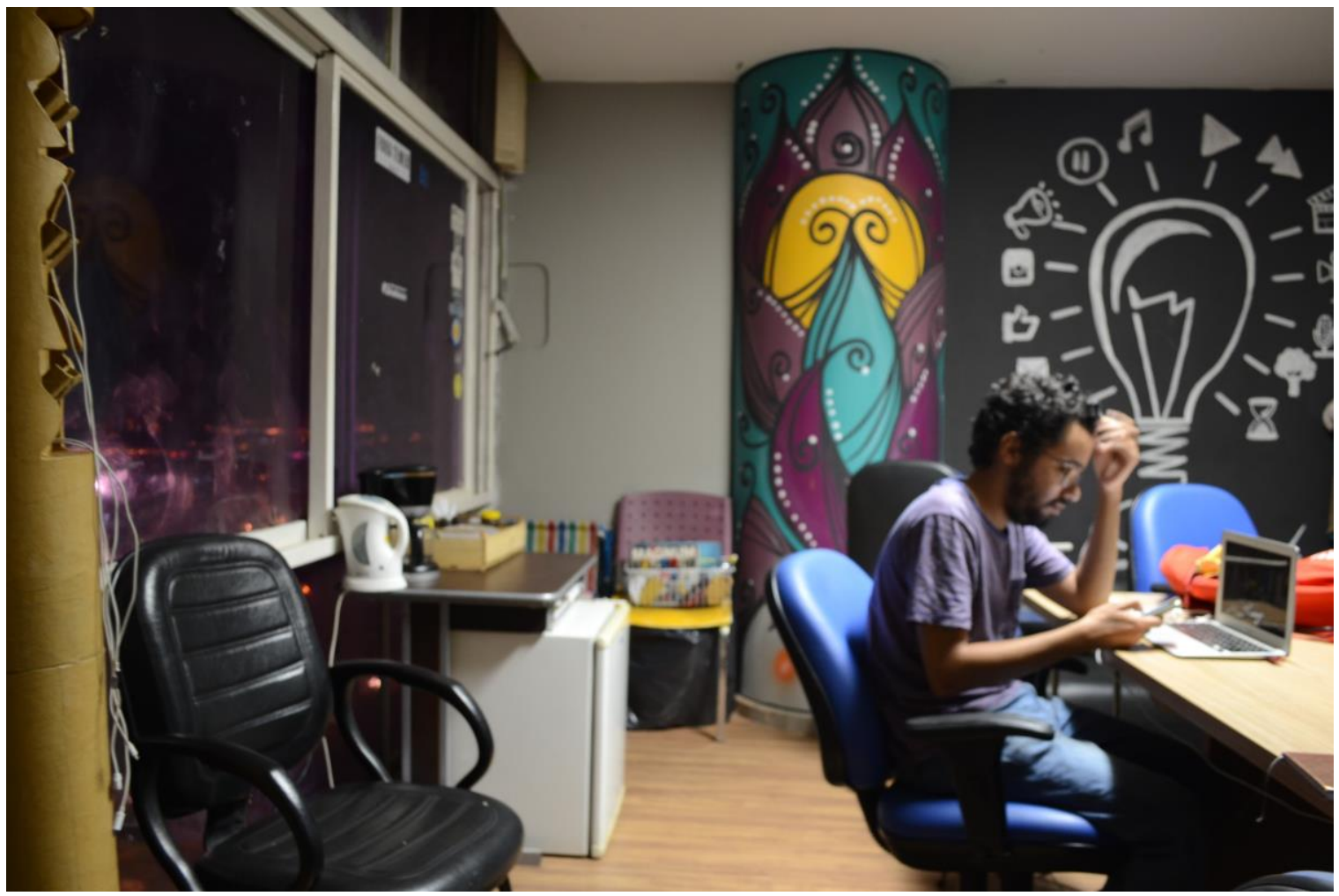

Foto: Fernanda Bastos

Como a observação participante foi realizada na tenda de comunicação do Acampamento Terra Livre - ATL - é importante descrever esse ambiente, que mesmo sendo provisório e temporário, foi essencial para o entendimento da cultura e do clima da Mídia Ninja. A tenda de comunicação ficou localizada ao lado do Museu dos Povos indígenas em Brasília. Ao redor existiam várias barracas improvisadas de madeira nas quais os indígenas vendiam colares, brincos e outros elementos culturais. O local não era de fácil acesso, pois fica longe da rodoviária, no entanto, alguns ônibus passam pela região. A tenda, no primeiro dia, ainda não havia sido montada e os ninjas ficaram embaixo de uma árvore. No segundo 
dia, a tenda branca com chão de metal, com tomadas nas paredes e mesas de plástico enfileiradas ao centro com cadeiras de plástico em volta já estava pronta.

A equipe que estava na tenda estava, em sua maioria, sentada digitando no computador, a outra parte estava andando pela tenda conversando no celular com fontes. $\mathrm{O}$ ritmo era febril e agitado, as pessoas nem conversavam entre si e digitavam de forma veloz no computador ou celular. As poucas conversas que ocorreram eram para tirar dúvidas ou passar alguma informação de pauta e eram diretas e bem rápidas. O tom de voz era baixo, mas quando existiam comunicados direcionados a todos, a fala era realizada em um tom mais alto. O nível de ruído do ambiente era alto, pois à tarde os povos indígenas realizavam apresentações na tenda principal que ficava ao lado da de comunicação e durante a noite ocorriam shows, palestras e transmissões ao vivo em um telão.

IMAGEM 8: Reunião de povos indígenas na tenda principal do Acampamento Terra Livre



Foto: Fernanda Bastos

Em Belo Horizonte, a Mídia Ninja, como explicado anteriormente, não tem um outro local de trabalho, sendo a casa a sede das reuniões. Localizada no bairro Floresta, próximo ao centro da cidade e de fácil acesso por meio de ônibus, a casa fica em frente ao viaduto Francisco Sales. 
A casa de dois andares amarela com portões brancos na esquina do quarteirão, tem cerca elétrica e uma garagem na frente. $\mathrm{O}$ interior é composto por quatro quartos, uma cozinha, uma sala de jantar, um local de trabalho e uma sala de estar, no térreo. No segundo andar existem mais três quartos. Os locais de convívio da equipe são a cozinha, a sala de estar, o escritório e a sala de jantar que tem paredes amarelas claras. Na sala, existem letras e papéis colados para a organização de eventos futuros, há uma obra de arte no canto perto da janela com um banco de madeira e um cartaz escrito "a cada 11 minutos, uma mulher é estuprada no Brasil". Há também uma estante repleta de livros, dois sofás e uma mesa. Na sala de jantar há uma estante para guardar as louças, uma mesa de jantar com cadeiras ao redor e um espelho. No escritório existem duas mesas, algumas cadeiras e um armário amarelo.

IMAGEM 9: Sala da casa Mídia Ninja Minas localizada em Belo Horizonte.

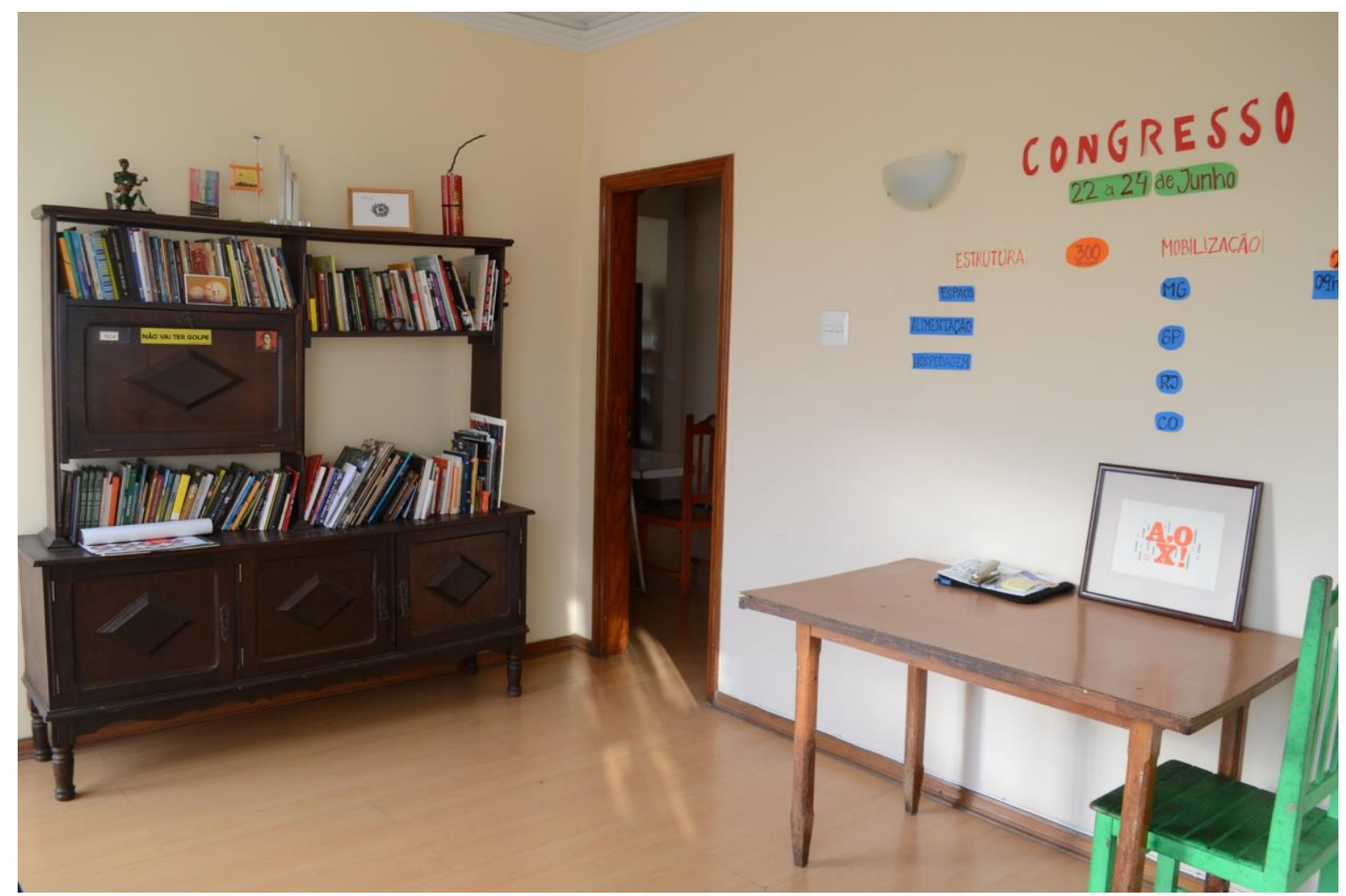

Foto: Fernanda Bastos

As pessoas na casa estavam todas sentadas em diferentes cômodos, escrevendo textos e trabalhando em seus computadores. Em alguns momentos alternados se levantavam para beber água ou comer algo na cozinha. O ritmo perceptível da organização era lento em relação às conversas entre eles, todos conversavam calmamente uns com os outros, mas 
agitado no que diz respeito ao trabalho realizado, todos estavam muito atentos e conectados realizando suas atividades. O nível de ruído na casa é alto por se localizar em frente ao viaduto.

IMAGEM 10: Thanee Degasperi trabalhando no escritório da casa Mídia Ninja Minas.

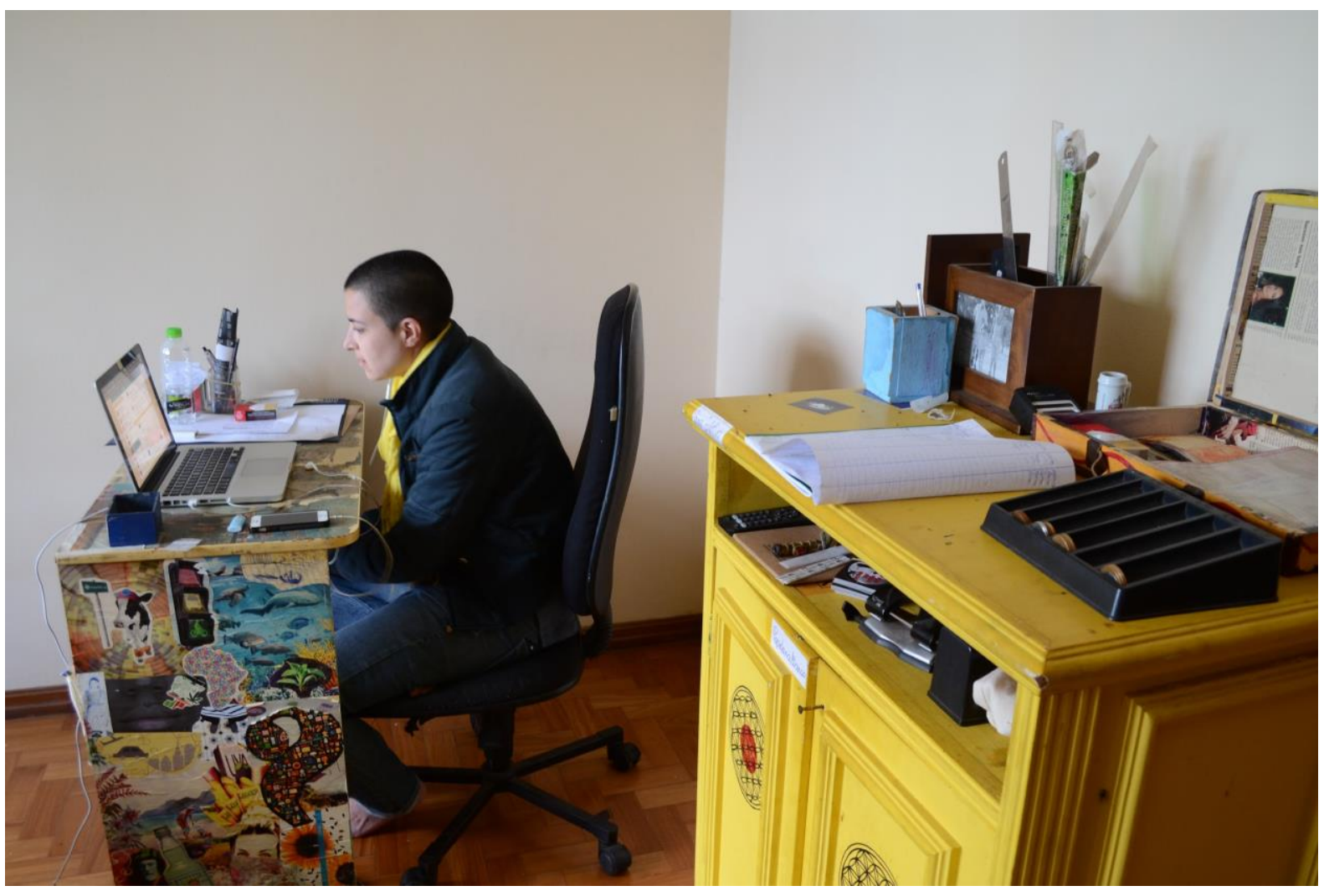

Foto de: Fernanda Bastos

\subsection{A cultura organizacional da Mídia Ninja}

A observação participante e as entrevistas foram as principais ferramentas metodológicas utilizadas para perceber a cultura e o clima organizacional da Mídia Ninja. No entanto, o questionário também realiza algumas questões sobre esses elementos da organização. Dessa maneira, os resultados abaixo mostram a miscelânea das três ferramentas metodológicas utilizadas no trabalho.

A identidade da Mídia Ninja é um dos pontos de estudo da cultura organizacional e tanto no questionário quanto nas entrevistas essa questão foi abordada. Com a utilização de uma hierarquia mental de palavras, os respondentes do questionário puderam elencar as três palavras que eles associavam e consideravam mais importantes ao pensar na Mídia Ninja. As palavras que mais se repetiram foram colaboração (duas vezes), rede (duas vezes) e 
midialivrismo (duas vezes). As palavras citadas pelos respondentes foram agrupadas em três grupos para análise: constituição e funcionamento da rede; ativismo e valores.

IMAGEM 11: esquema de organização das palavras relacionadas a Mídia Ninja pelos respondentes do questionário.

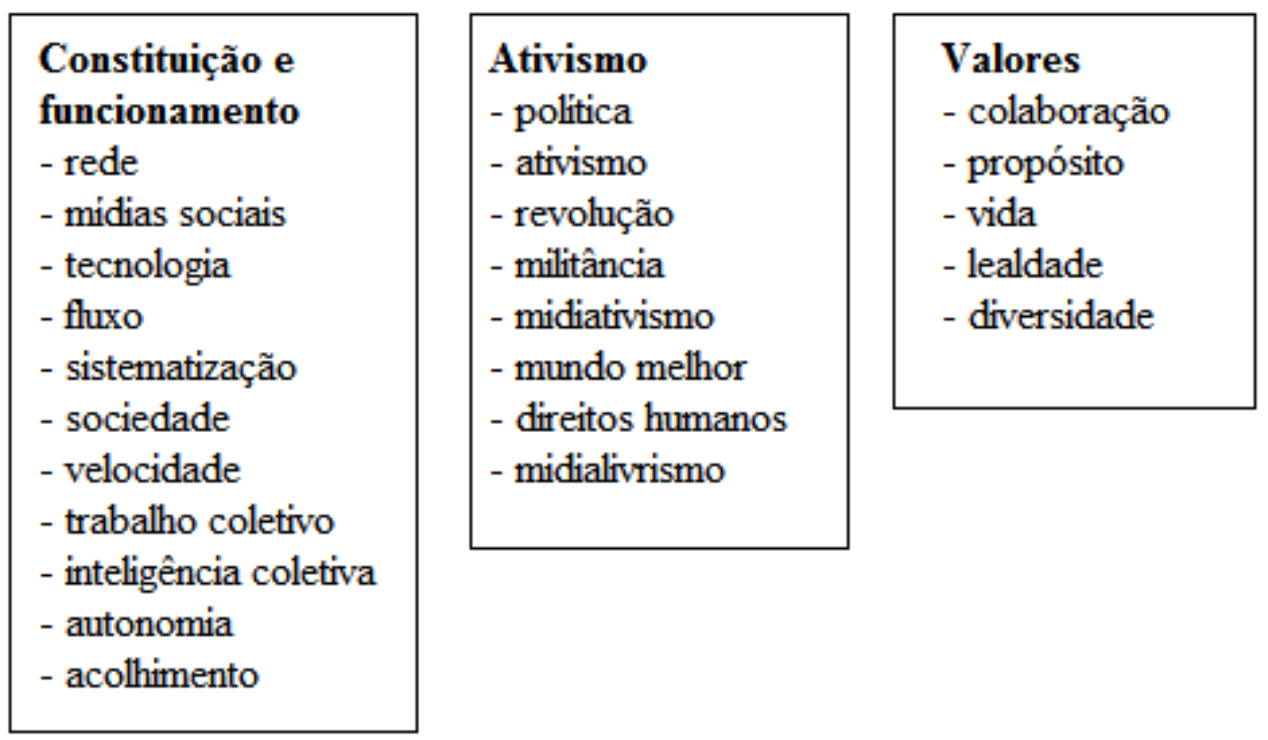

Fonte: Fernanda Bastos. Trabalho de campo, 2018.

Essas palavras aparecem diversas vezes nas respostas da pergunta sobre a identidade da Mídia Ninja para os entrevistados. Thalles Lopes, um dos fundadores da organização e coordenador da casa Minas, afirma que a essência da Mídia está pautada no modo de vida comunitário que se relaciona com os valores da mesma. De acordo com o ninja,

existe uma forte organicidade, relações de confiança estabelecidas por um longo período, tanto dessas pessoas que vivem na casa e escolheram viver dessa forma como também uma definição do que seriam alguns princípios e valores que a Mídia Ninja defende. Desde quando ela surge em 2013, um dos primeiros debates que existiram foi dela assumir um lado, de não ter problema em defender determinados pontos de vista a partir de um conjunto de valores que acreditamos. E esse conjunto de valores não está só em uma carta, ele tá enraizado nesses espaços que a gente construiu para poder viver e nesse modelo de vida que temos, que é compartilhado, colaborativo, comunitário. A gente acaba expressando na nossa linha editorial, para além de uma visão de mundo, um modo de vida também. [...] E a essência é traduzida no modo de vida das pessoas que construíram o processo. É uma perspectiva de vida comunitária, as pessoas vivem juntas, compartilham desde a criação dos filhos até a comida, até a organização do espaço, a limpeza dos lugares. (Tales Lopes, em entrevista para a pesquisa, 2018). 
Na fala de Gustavo Santos, colaborador no Distrito Federal, ele coloca a Mídia Ninja como um ator político que se articula com diversos movimentos políticos. Outros membros afirmam enxergar a Mídia Ninja como uma rede de ativistas de mídia e de outras causas e como um veículo de contrainformação. Cláudia Schulz, ninja responsável pela articulação política e monitoramento das redes que atualmente trabalha na casa São Paulo, afirma que "A Mídia Ninja é uma tecnologia de e para o bem comum contar suas narrativas e contranarrativas. Narramos as utopias para a construção de um novo mundo possível. "' (Cláudia Schulz, em entrevista para a pesquisa, 2018).

Para alguns dos entrevistados, houve a questão sobre a identidade organizacional da Mídia Ninja. Traduzida pela pergunta, se ela fosse uma pessoa, os ninjas, resumindo as respostas, acreditam que seria uma mulher, empoderada, militante que se interessa pelas pautas da esquerda, pelos movimentos sociais, seria pansexual, corajosa e generosa. De acordo com Gustavo Santos, seria uma “jovem, comunicativa acima de tudo, multitarefas e que tem disposição de participar, construir junto em vários espaços e se articular e de trabalhar com a comunicação. " (Em entrevista para a pesquisa, 2018). Para alguns ela seria a junção de todos os integrantes da Mídia Ninja. Esse conjunto de representações, junto com o entendimento de cada indivíduo sobre si mesmo e sobre a organização estabelecem um olhar interno comum, repleto de significados sobre a identidade da Mídia Ninja.

Em todas as entrevistas é perceptível a ideia de colaboração em rede, da vida coletiva, sendo parte essencial da essência da Mídia Ninja. O que é irradiado para outras esferas além da interna, como para o relacionamento com os parceiros e movimentos sociais que colaboram enviando imagens, sugestões de pautas, vídeos. Também atinge internautas e leitores que contribuem com a rede, influencia a linha editorial da Mídia, que colabora com diferentes movimentos, mostrando notícias que não seriam nunca divulgadas em grandes canais de comunicação. A colaboração é um dos valores intrínsecos na construção da identidade da Mídia Ninja. Assim como evidenciado por uma das fundadoras do coletivo, Cláudia Schulz, "confiança, colaboração e trabalho em rede são princípios que conectam a relação entre trabalhadores, sociedade, movimentos sociais, entre outros. " (Entrevista para a pesquisa, 2018).

Outros valores, destacados nas entrevistas, são a defesa dos direitos humanos, da democracia, dos direitos humanos identitários, a luta feminista, a luta do movimento negro, combate a LGBTfobia, combate ao racismo, ao machismo. Visibilizam pautas de comunicação, cultura alternativa, meio ambiente e descriminalizam pautas como a juventude 
marginalizada. Um outro valor constituinte da organização é a solidariedade. Segundo Clayton Nobre, coordenador da universidade na casa Brasília, "a nossa economia se moveu muito a partir da solidariedade, em exemplos práticos, trocas de serviços e produtos, economia colaborativa. Fundamos nosso banco a partir disso, do princípio de solidariedade, esse é um valor essencial. " (Clayton Nobre, entrevista para a pesquisa, 2018).

A moeda social, Fora do Eixo Card, é uma das estratégias organizacionais adotadas pela Mídia Ninja, que de acordo com Clayton, a mídia se utilizou dessa tecnologia para "suprir uma necessidade. Ela pode ser replicada por outros coletivos da própria rede e não é uma ideia centralizada em um coletivo em um único espaço. A moeda nasceu em Cuiabá, no DNA do Fora do Eixo, que foi a incubadora de várias tecnologias que a gente utiliza até hoje, moeda social, casas coletivas." (Clayton Nobre, entrevista para a pesquisa, 2018).

Como as principais estratégias utilizadas pelas Mídia Ninja, podemos elencar de acordo com as entrevistas, além da moeda social, citada anteriormente, a retroalimentação do sistema, as casas coletivas, a escola de midiativismo e a política de estímulos para o público interno. Segundo Cláudia Schulz,

Cada coletivo possui uma série de expertises desenvolvidas na prática da produção cultural, como transmissão ao vivo, webrádios, monitoramento de redes, técnicas de fotografia e audiovisual. A partir do contato em rede, desenvolveram-se metodologias para que a troca de tecnologias fosse de fato efetivada: observatórios, circulação dos agentes, vivências, imersões. [...] A Mídia NINJA possui mais de 30 editoriais e um diálogo constante com inúmeros movimentos sociais, ativismo, cultura entre outros. A diversidade de frentes, de linguagens e de pautas somadas a relação faz com que os conteúdos também conectem diferentes atores por meio de um campo de articulação política que poderia ser inimaginável. Trabalhamos muitas vezes fora da curva, ou seja, não trabalhamos na produção de conteúdo dentro da previsibilidade. [...]. Nós também somos uma escola de midiativismo. A formação é um dos principais pilares da Mídia NINJA. Não atuamos pela competição, pela concorrência ou pelo furo jornalístico. Atuamos para multiplicar. Por meio de encontros, imersões, oficinas e cartilhas já formamos mais de 2 mil cidadãos multimídia que hoje atuam como colaboradores, ou formaram suas próprias iniciativas de mídia livre. Como resultado desse processo, já nasceram empreendimentos como Faccion, a rede latino-americana de notícias, Midia INDIA, rede indígena de mídia livre e difusão das causas indígenas e ambientais, além de núcleos de comunicação de diversas organizações sociais, incluindo população sem teto, sem-terra, movimentos estudantis, ativistas culturais, entre outros. No último ano, nossa escola de midiativismo transformou-se no LAB NINJA e abrimos um edital para vivência e formação com mais de 3 mil pessoas interessadas de diversas cidades da América Latina. [...] Nossa principal moeda é o estímulo, quando o ambiente e as pessoas estão no máximo de sua potência, produtivas, ativas, harmônicas, criativas, é porque ali tem muita energia retroalimentada por um processo coletivo onde os sentimentos e emoções importam e contribuem significativamente para a nossa economia interna. (Cláudia Schulz, em entrevista para a pesquisa, 2018). 
Essas estratégias são utilizadas para que a Mídia Ninja consiga atingir seus principais objetivos que consistem em dar visibilidade aos grandes problemas sociais, descriminalizar pautas e causas criminalizadas e marginalizadas, construir guerras de narrativas, mostrar o outro lado da história, obter conquistas públicas por meio da comunicação e colaborar para que mais atores possam produzir suas próprias narrativas. Segunda Cláudia,

\begin{abstract}
A Mídia Ninja é uma rede midiativista distribuída pelo Brasil, que incide diretamente nas disputas de imaginário contemporâneas e colabora com a obtenção de conquistas públicas, mobilizando centenas de cidadãos para produzirem suas próprias narrativas. Assim, damos voz e visibilidade a grupos historicamente marginalizados, atuando na contramão dos interesses do sistema de comunicação corporativo no Brasil. Entendemos a comunicação democrática como um direito humano e defendemos o interesse público, a diversidade cultural e o direito à informação, visibilizando pautas de comunicação, causas identitárias, cultura, meio ambiente, juventude e outras que dialogam com os desafios do século XXI. (Cláudia Schulz, em entrevista para a pesquisa, 2018)
\end{abstract}

$\mathrm{O}$ advento da internet e as novas tecnologias influenciam a cultura organizacional da Mídia Ninja e moldam as comunicações - conversas, comunidades, reuniões - estabelecidas dentro da organização. A tecnologia para os ninjas foi essencial para conseguirem se organizar como comunicadores e narradores, afirma Clayton Nobre (em entrevista, 2018). A maior parte das conversas, dos feedbacks, das reuniões, se dá por meio do Telegram, "uma ferramenta open source com vários atributos, como criar supergrupos com mais 100 pessoas, chats criptografados, cache na nuvem que permite armazenamento de arquivos sem ocupar memórias dos aparelhos. " (Cláudia Schulz, em entrevista, 2018). Por ser uma rede espalhada por estados do Brasil, a comunicação tem de ser eficaz e rápida. Utilizando esse tema em uma das perguntas do questionário, a comunicação interna é percebida e realizada de forma eficaz pelos membros da Mídia Ninja Belo Horizonte e Brasília, visto que nove das nove respostas obtidas foram positivas, afirmando que a Mídia Ninja tem uma comunicação entre colaboradores e membros da equipe orgânica eficiente. 
IMAGEM 12: respostas da questão sobre eficiência da comunicação interna da Mídia Ninja.

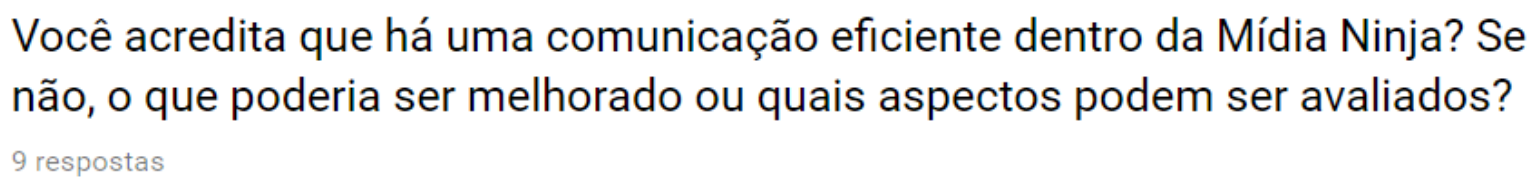

acredito que sim. a gente tem o costume de se falar bastante e fazer os fluxos e alinhamentos necessários sempre para que não haja nenhum problema, durante as coberturas, no dia a dia, em especial os times que estão em campo e os times que estão na "base" e dão suporte aos times em campo. Nos falamos bastante, rápido, priorizamos manter a conexão para que isso seja fluido também, que as cobranças não sejam interpretadas como pegação no pé ou críticas apenas, mas sejam motivos de repensar, de mudar e avançar.

Acredito que sim, não enxergo nenhum gargalo na nossa comunicação

A comunicação é a chave importante para que saibamos como estão os nossos por exemplo em um ato ou numa cobertura colaborativa. É importante saber de todas as fragilidades dos nossos.

Fonte: Fernanda Bastos. Trabalho de Campo, 2018.

Com 32 chats no Telegram, a Mídia Ninja atua com a divisão dos grupos em frentes de linguagem (fotografia, texto, vídeo, design, redes sociais) e cada um desses tem seu gestor que gere desde a cobertura até a postagem. O grupo de editoria opina sobre as pautas que serão divulgadas nas mídias sociais da organização e há também grupos para coberturas específicas como, por exemplo, o da cobertura do Acampamento Terra Livre. Um dos problemas percebidos durante a pesquisa é que os erros recorrentes dos colaboradores iniciantes ocorrem por existirem uma série de etapas de aprovação nas quais a informação deve passar para chegar às redes sociais da Mídia Ninja e também por existirem muitos grupos no Telegram. Uma outra questão levantada é a utilização exagerada dos celulares pelos membros, que muitos afirmam estarem conectados $24 \mathrm{~h}$ por dia para não perderem nenhuma pauta que venha a chegar por um dos grupos de parceiros.

Utilizando um smartphone é possível se conectar com a rede e não somente isso, mas também é possível transmitir ao vivo, fotografar imagens de alta qualidade. De acordo com Louise Akemi, coordenadora do núcleo de sustentabilidade,

Isso gera uma mini revolução no como fazer comunicação hoje, você não precisa de um mega estúdio, não, temos equipamentos muito simples, não temos grandes conhecimentos, nem todos são formados e nem todos têm 
técnica, mas o fato de ser uma rede, possibilita que os conhecimentos sejam passados de um pro outro. (Louise Akemi, em entrevista para a pesquisa, 2018).

Essa rede, tem como princípios da gestão, a colaboração. Assim, as decisões são coletivas, característica da cultura Hacker que é intrínseca a organização ninja. Uma das perguntas do questionário era sobre a influência que o membro tem nas resoluções da Mídia Ninja. Das nove respostas nenhuma foi negativa, houve oito respostas afirmando que tem o poder de influenciar nas decisões da organização e uma resposta talvez.

A estrutura organizacional da Mídia Ninja é definida como horizontal, com uma base democrática. Como afirmado por Louise, "é um modelo horizontal, coletivo que valoriza a formação do indivíduo, a diversidade, as mulheres e isso também se torna um ponto positivo para não ser uma empresa que funciona verticalmente" (Louise Akemi, em entrevista para a pesquisa, 2018). Esse sistema de organização, segundo Talles Lopes, constitui "uma essência muito mais ligada a forma de organização das comunidades tradicionais, dos povos indígenas brasileiros, da resistência quilombola, do que um modelo ocidental de organização coletiva a partir de interesses, que geraram partidos, sindicatos". (Talles Lopes, em entrevista para a pesquisa, 2018). Outros entrevistados afirmam que a construção organizacional da Mídia Ninja é dada por experiências, quanto mais tempo e vivências dentro da rede, mais você será visto como um líder. De acordo com Thanee Degasperi,

Acredito que seja muito pautada pela questão da vivência, das experiências. Os fundadores da Mídia Ninja, que estão há mais tempo, carregam mais experiências, tudo, os valores, as ideias são mais inerentes. Não me coloco no mesmo lugar que eles, não tenho essa construção, é isso, é pelo que você constrói dentro da rede. A minha construção é a pauta internacional, tenho um conhecimento mais aprofundado por ter feito um curso com esse tema e gosto de atuar nessa área dentro da Mídia. Você cria a sua história ali dentro, pronto pro "game", você constrói a sua persona ninja. Claro que deve existir uma conexão com a editoria, existe uma hierarquia orgânica na horizontalidade, você precisa entender o seu lugar, muitas vezes entender o nosso ego e desconstruí-lo. (Thanee Degasperi, em entrevista para a pesquisa, 2018).

Thanee, ao citar desconstrução do ego, estabelece essa relação com a convivência compartilhada. Morar e trabalhar no mesmo local reflete na cultura e no clima organizacional da empresa. Como destacado por alguns entrevistados, na maior parte do tempo o clima é harmônico, mas existem brigas e a convivência é complicada às vezes, o que pode causar problemas como o desgaste emocional e a saída de alguns membros. Entender como os participantes da equipe orgânica enxergam o ambiente de trabalho, como entendem o envolvimento com os colegas é essencial para o entendimento dessa dinâmica de casas 
coletivas. Segundo Cláudia, as casas "são espaços conectados, temos um fluxo constante e diário de comunicação, planejamento e interação. Elas são pilares estruturantes das bases de trabalho da Ninja”. Isis Maria, afirma durante a entrevista que precisou desconstruir alguns vícios que tinha da criação com seus pais para estabelecer uma convivência harmoniosa na casa. De acordo com Isis (entrevista, 2018), "é preciso ceder em algumas coisas e avançar em outras. Isso faz com que o processo seja rico, você vai desconstruindo alguns preconceitos e avançando em outros pontos". Para estabelecer essa relação é preciso muito diálogo e muita confiança uns nos outros, é preciso "se sentir em casa", que é como Thanee se sente,

Primeiro de tudo é que é a minha casa, me sinto em casa. Tenho liberdade para poder explorar pautas que me interessam, as decisões são sempre coletivas, as coisas são bem encaminhadas e as ideias vem prontas. As pessoas já chegam com a solução, pra que criar problemas. Eu vejo o mundo profissional como um local onde impera o medo de se expressar e na Mídia Ninja é diferente, existe a generosidade, cuidado, carinho com o outro. Os feedbacks ocorrem de maneira construtiva, conversas diretas são comuns na casa, colocar os pontos nos is, a resolução dos problemas é rápida, até por meio do Telegram, o papo é reto, é na hora, isso estimula o crescimento da rede. (Thanee Degasperi, em entrevista, 2018).

O diálogo e a comunicação entre os membros e entre eles e os líderes foi tema de duas perguntas no questionário. Entre os membros, a comunicação foi caracterizada mais vezes (oito votos) como fácil, depois como rápida (sete votos), em seguida como eficaz (seis votos), logo depois como comum (quatro votos) e livre e aberta com um voto. Já a comunicação entre os membros e os líderes foi caracterizada mais vezes como fácil (nove votos), depois como eficaz e rápida (cinco votos cada), seguida por comum (quatro votos) e livre e aberta (um voto).

IMAGEM 13: respostas sobre características da comunicação entre os membros.

\section{Como é a comunicação entre seus colegas e você?}

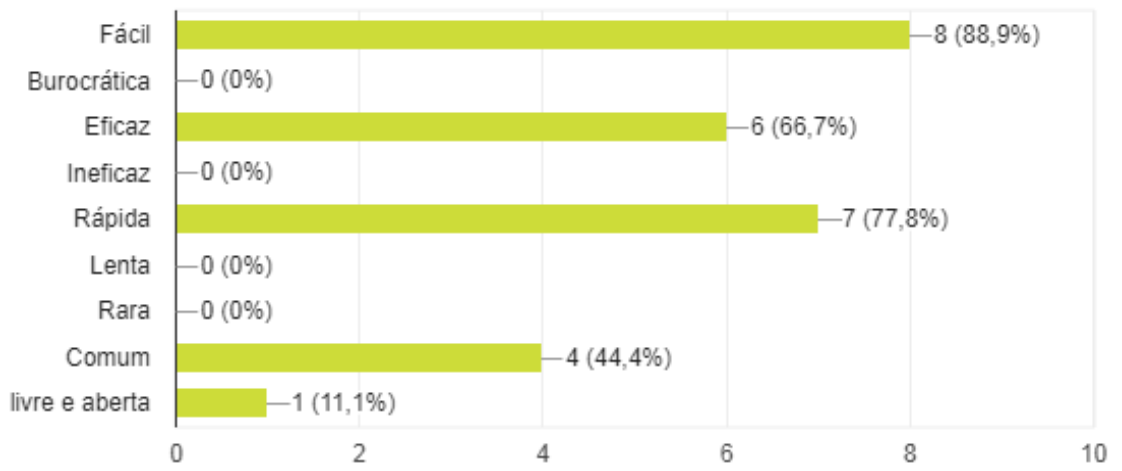

Fonte: Fernanda Bastos. Trabalho de Campo, 2018. 
IMAGEM 14: respostas sobre características da comunicação entre os membros e líderes.

\section{E entre os líderes e você?

\author{
9 respostas
}

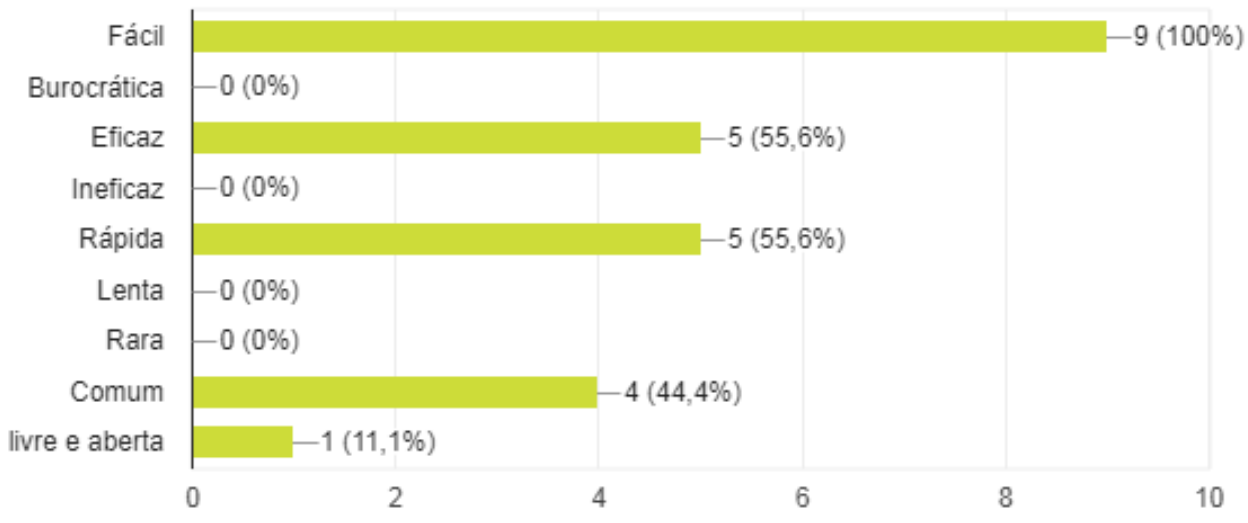

Fonte: Fernanda Bastos. Trabalho de Campo, 2018.

Thalles Lopes (em entrevista, 2018) acredita que houve a criação de um "ambiente onde na nossa vida cotidiana, nas nossas práticas somos orientados pelos valores que acreditamos que devem orientar a sociedade como um todo". Por meio da criação de um espaço de amplo diálogo, de acolhimento, conversas, onde não há um ambiente de meritocracia e qualificação, onde todos ali são valorizados pela função que desempenham, seja de varrer o chão ou a de cobrir matérias, todos contribuem para a existência da Mídia Ninja. E nesse ambiente, de acordo com Clayton,

As pessoas começaram a se relacionar dentro da rede, as crianças começaram a nascer, vira uma relação praticamente familiar, a relação é muito diferenciada. Eu acho que essa é a grande pérola da pesquisa, não é uma organização como as outras. Não quer dizer que a gente não se organize, é diferente de uma relação familiar, mas temos trocas constantes de comunicação, executamos os projetos com dedicação exclusiva à Mídia Ninja. Hoje estamos em um momento em que todos da equipe orgânica são $100 \%$ dedicação exclusiva, 24 horas. (Clayton Nobre, em entrevista, 2018).

Esse contato diário, de $24 \mathrm{~h}$ por dia, estabelece além de relações fortes e abertas de companheirismo, o compartilhamento de crenças e filosofias comuns entre os membros da equipe Mídia Ninja, que atingem até os colaboradores. Algumas delas, citadas nas entrevistas, são que a Mídia Ninja tem um lado, uma linha política e ideológica de defesa dos direitos humanos, de representatividade e de posicionamento político de esquerda declarada. Os ninjas não acreditam no mito da imparcialidade. De acordo com Cláudia, 
A Mídia NINJA tem lado. Acreditamos que imparcialidade não existe, e por isso assumimos nosso lugar de fala a partir da defesa da democracia, da diversidade cultural e de um posicionamento editorial transparente e direto. Nossa editoria é coletiva e defende o interesse público, o direito à informação e ampla visibilidade de pautas e movimentos sociais ligados aos direitos humanos, comunicação, cultura, moradia, política, economia, meio ambiente e outras agendas que dialogam com os desafios do século XXI. (Cláudia Schulz, em entrevista, 2018).

Definem-se como uma mídia cidadã, que defende os direitos dos movimentos e causas que apoiam e lutam por conquistas públicas. Acreditam que a comunicação é o meio de empoderamento que vai promover a conquista desses objetivos, que comunicação é poder, ela é o "instrumento que utilizam para o ativismo" (Clayton Nobre, em entrevista, 2018). Clayton afirma ainda que a Mídia Ninja não busca reproduzir o padrão capitalista e a lógica mercantil de separação do dia em horas de descanso, de lazer e de trabalho. Trabalhar para ganhar dinheiro perde sentido dentro da cultura organizacional da Ninja. Não existe a ideia de concorrência, na verdade, uma outra crença que se faz muito presente em diversas entrevistas é "atuamos para multiplicar" (Cláudia Schulz, entrevista, 2018). Quanto mais mídias alternativas, melhor, maior é o fortalecimento do ecossistema da comunicação e mais narrativas entrarão na rede.

\subsection{O clima organizacional da Mídia Ninja}

Durante a observação participante foi possível perceber que tanto no Acampamento Terra Livre como na casa Mídia Ninja Belo Horizonte que a comunicação entre os integrantes da equipe é gentil. São atenciosos uns com os outros, se tocam ao conversar e existe o clima de informalidade entre eles, já que ficam muito tempo juntos quando não estão cobrindo as pautas. Existem práticas informais de comunicação, falam sobre assuntos além do trabalho como filhos e relacionamentos. Uma das questões do questionário era sobre as relações no trabalho e amizades. Dos nove respondentes, todos afirmaram que possuem boas relações e amigos na Mídia Ninja.

Um outro elemento analisado na pesquisa é o comprometimento dos ninjas com as atividades que devem desempenhar. A maioria dos entrevistados afirmou se envolver de forma profunda com os as pautas e os movimentos que realizam coberturas. A equipe orgânica é $100 \%$ dedicada ao movimento e ainda se capacitam para desempenhar multifunções. Outros afirmaram que há a junção de vida profissional com a pessoal e que nem chegam a considerar como trabalho, mas como vida. De acordo com Thalles, a pessoa que quer ser um ninja 
tem que estar disposta a fazer parte desse processo de construção desse modo de vida. Isso determina essa relação interna, as pessoas vem pra cá porque querem. Existe um nível de dedicação que está relacionado a isso, o compromisso, se a pessoa às vezes se dispõe a trabalhar mais ou a acordar cinco horas da manhã porque tem uma pauta que tem que acompanhar é porque ela tem um compromisso com aquilo que é pra vida dela. Não é porque o Thales tá pedindo. Isso facilita a cobrança interna, não precisa ficar cobrando, cada um tem a consciência de que se ele não fizer vai prejudicar os parceiros e movimentos. (Thalles Lopes, em entrevista, 2018).

Uma das perguntas do questionário é sobre o sentimento de responsabilidade sobre o seu trabalho, sobre as atividades que desempenha. Das nove respostas, oito membros afirmaram que acreditam ter um alto nível de responsabilidade trabalhando com a Mídia Ninja e uma pessoa afirmou que tem o nível médio de responsabilidade em relação ao trabalho.

A dedicação exclusiva, esse alto nível de compromisso se deve por motivações, alguns entrevistados responderam que dar voz às pessoas que são invisibilizadas, descriminalizar os movimentos são alguns dos motivos. Clayton Nobre (entrevista, 2018) afirma que "nós temos duas grandes motivações: ou queremos dar reverberação que aquela pauta não tem, queremos que ela circule nas redes, dar luz a causa ou somos ativistas de mídia, muitas pautas tem o interesse como participante e ativista do movimento".

Outros entrevistados acreditam que a liberdade e autonomia de poder trazer temas e pautas diferenciadas, diversidade de editorias e a liberdade de poder escrever sobre a pauta sem represálias de nenhum órgão privado ou político, motivam os integrantes da Mídia Ninja. A flexibilidade de uma empresa que não tem estruturas organizacionais extremamente padronizadas e formais e o ambiente de trabalho que tem um clima acolhedor de generosidade que instiga o crescimento pessoal e profissional, são alguns dos outros motivos para tamanha dedicação, como afirmado por alguns entrevistados. Em relação a pergunta sobre crescimento profissional, dos nove respondentes do questionário, oito acreditam que as tarefas que desempenham na Mídia Ninja ajudam no crescimento profissional, um respondente, acredita que é com uma frequência média que as tarefas desempenhadas o (a) ajudam a crescer profissionalmente.

As casas regionais têm gestores que organizam desde o dia a dia de organização da casa como a distribuição das pautas. No entanto, esses gestores da rede e do movimento social que é a Mídia Ninja são vistos pelos integrantes da Mídia Ninja como líderes e não como chefes de redação. A relação entre os membros e os líderes é de afeto, de confiança e é muito orgânica. De acordo com Talles Lopes, gestor da casa Mídia Ninja Belo Horizonte, "o que caracteriza essa gestão interna, são essas relações de confiança e identificação com aquilo que a gente defende e acredita. Ninguém está aqui obrigado, por contrato. São os valores, primeiro 
a pessoa tem que se identificar com isso". (Talles Lopes, em entrevista para a pesquisa, 2018). A importância dos gestores não só na organização da casa e das tarefas, mas também na garantia do funcionamento da dinâmica é evidenciada por Isis Maria,

Esses gestores têm também a missão de cuidar para que as coisas não se percam, tem cuidado com o todo, com a manutenção de deixar todos confortáveis, nivelados e tranquilos para realizar suas funções. A dinâmica rolando, as pessoas confortáveis se sentem estimuladas para o que estamos fazendo, então isso faz com que consigamos estar contentes para trabalhar, pra fazer as coisas que precisamos fazer, isso é uma das coisas que conta mais até no Ninja, eu acho, tem muito a ver com o estímulo. (Isis Maria, em entrevista para a pesquisa, 2018).

A questão da realização de feedbacks entre os membros e entre os membros e líderes foi levantada em duas perguntas do questionário. A maioria dos respondentes afirmou que o diálogo é constante e horizontal entre os membros, realizado de forma rápida e direta, realizado em sua maioria por meio online e que o resultado das conversas é satisfatório. 
IMAGEM 15: respostas sobre feedbacks realizados entre membros.

\section{Como você realiza feedback e sugestões para a empresa? São escutados? Quais são os resultados?}

9 respostas

Dos leitores e colaboradores da Midia NINJA, a equipe de atendimento coleta diariamente os feedbacks especialmente por e-mail e redes sociais.

Via conversas e o resultado é satisfatório

Temos momentos de avaliação, são frequentes, e as sugestões/propostas são avaliadas coletivamente de forma horizontal.

O diálogo é diário, de confiança e entrega.

Relato diretamente a quem necessita ouvir, são escutados e em geral encaminhados

Primeiramente que não entendemos a NINJA como uma empresa e dentro de sua gestão coletiva a lógica de empresa não se encaixa, pois estamos falando de um organismo vivo, coletivo e colaborativo em sua raiz. Passamos feedbacks o tempo todo uns para os outros como forma de compartilhamento de informação, conhecimento e aceleração do refinamento do nosso trabalho. Os resultados são uma equipe coesa, com velocidade no nivelamento político e atuação veloz tanto na parte de criação quando na necessidade de reação há algum fato.

temos um fluxo diário e tempo real. geralmente nos falamos bastante sobre como encaminhar os textos, postagens, fotos, coberturas. chamamos isso de alinhamento, e vamos fazendo isso conforme as coisas vão acontecendo. esse alinhamento durante o fluxo traz os feedbacks rápido, podendo mudar de estratégia numa cobertura que não tá rolando legal por ex, e também fazemos avaliações depois, com relatórios, análises de redes sociais etc

O contato é direito, nos falamos durante o dia, qualquer questão é tratada na hora, ou pouco tempo depois, os resultados sempre positivos, afinal, essa é a ideia da relação e da vida coletiva

A gente se reúne e sempre traça o melhor plano escutando a todas as pessoas afim de fazer um trabalho coletivo que nos represente em gênero, sexualidade e raça

Fonte: Fernanda Bastos. Trabalho de Campo, 2018.

Na outra questão sobre feedbacks entre líderes e membros, como a informação é sempre compartilhada, feedbacks construtivos são mais frequentes. São recebidos com mais frequência pelo meio online, na plataforma de comunicação Telegram, pois muitas vezes, os líderes estão em outras cidades. Um dos respondentes, afirmou morar junto com o líder e assim, a comunicação é realizada em tempo real, de forma orgânica. 
IMAGEM 16: respostas sobre feedbacks realizados entre líderes e membros.

\section{Como você recebe sugestões e feedbacks do líder ou de outros colegas da Mídia Ninja? São construtivos? \\ 9 respostas}

Sempre construtivos. Como moramos juntos, as leituras são feitas em tempo real, de forma orgânica.

Via oral. Sim.

São construitivos e recebo de forma aberta, buscando ouvir e seguir as orientações da melhor forma, que em geral, significam o melhor para o coletivo.

Geralmente são muito construtivos e bem aceitos.

Sim, sempre

Sim, recebo. São extremamente construtivos.

em geral a gente se fala nos chats das atividades mesmo - em especial da editoria ninja e redes ninja (que são os que mais usamos durante o dia de trabalho, encaminhando as coisas) - e as vezes em particular.

Recebo normalmente pelo Telegram, até porque são pessoas que em boa parte estão em outras cidades, é muito prático. Sim, é construtivo, a generosidade é muito importante para seguir firme e forte na luta

a gente tem como base o nosso crescimento e de quem nos acompanha, sempre damos feedback positivos quando são e quando não são tentamos transformar em algo positivo pra que todas as pessoas se sintam incluídas ao grupo

Fonte: Fernanda Bastos. Trabalho de Campo, 2018.

Foi possível estabelecer durante a pesquisa um paralelo entre as duas sedes da Mídia Ninja. A de Brasília tem como principais gestoras, duas mulheres, existem crianças na casa e por isso, muitas vezes o espaço de trabalho mais utilizado acaba sendo o do escritório do RUAS. Já em Belo Horizonte, a casa é gerida por um homem e uma mulher, não existem crianças e a casa é o local mais utilizado para o trabalho, inclusive tem um amplo espaço. No entanto, essas gestões são flutuantes, como explica Isis Maria, integrante da equipe de redes sociais,

Os projetos, esses gestores são flutuantes, então em determinado momento, o Tales, gestor da casa Minas, vai para Brasília e lá ele já não é mais gestor, lá tem as mulheres que já estão nesse processo. Então ele chegaria em Brasília não sendo gestor de lá, mas sendo gestor da música que é uma das coisas que ele toca. Diferente por exemplo de uma empresa, que o vice-presidente é o vice-presidente e não será outra coisa menor quando ele sai da sala de vicepresidente e entra no refeitório. Aqui, quando você é gestor de uma casa e vai pra outra, você não é o gestor da outra casa, você vai ser base das pessoas naquela casa, mas você vai continuar sendo gestor das linguagens que você domina dentro do processo. Diferente dessa estrutura quadrada, acho que temos essa maleabilidade aqui e que se a pessoa começa a desenvolver, se apaixonar e se estimular por alguma linguagem, a pessoa se torna gestor daquilo também. (Isis Maria, em entrevista para pesquisa, 2018). 
Um dos problemas percebidos, relacionado ao deslocamento dos membros para as cidades e locais onde há uma pauta urgente e de extrema importância para a organização, é a falta de divulgação e visibilidade que não são dadas para pautas das cidades que ficaram com menos integrantes da Mídia Ninja. Durante a entrevista de Clayton Nobre, ele afirmou que a parte cultural de Brasília durante a semana que só ele estava na capital não foi explorada, e para ele, a área cultural é um dos temas que ele mais se sente satisfeito em tratar.

A satisfação dos membros em participar da equipe da Mídia Ninja é perceptível nas entrevistas, com uma frase de Thanee (entrevista, 2018) "É uma vida, é uma missão. Somos todos militantes, vivemos para defender uma bandeira e essa bandeira é o povo. Causa LGBT, moradores rurais, trabalhadores, professores, entre outras. Nunca fui tão realizada e tão feliz. "A cultura organizacional, a estrutura e o envolvimento dos membros influenciam no sentimento de satisfação dos integrantes da equipe. Na última pergunta do questionário, a questão era sobre o que fazia o membro feliz em estar na Mídia Ninja. Das nove respostas, cinco $(55,6 \%)$ afirmaram que o que promove mais felicidade dentro da empresa são a ideologia e os valores da mesma. Dois respondentes $(22,2 \%)$ afirmaram ser a missão do trabalho. Uma das respostas $(11,1 \%)$ afirma que todos os elementos elencados - amigos/ colegas de trabalho, ambiente de trabalho, clima harmônico da empresa, estrutura organizacional, reconhecimento do trabalho, estabelecimento de novos contatos, missão do trabalho, ideologia e valores da empresa - contribuem para sua felicidade, foi uma escolha que tem 10 anos. Um outro respondente $(11,1 \%)$ afirmou que ambiente de trabalho, clima harmonioso, reconhecimento do trabalho e ideologia e valores são certamente alguns dos motivos que o fazem feliz dentro da empresa. 
IMAGEM 17: respostas sobre motivos de felicidade dentro da empresa.

\section{0 que te deixa mais feliz dentro da empresa?}

9 respostas



Amigos/ colegas de trabalho

Ambiente de trabalho

Clima harmônico dentro da empresa

Estrutura organizacional da empresa

Reconhecimento do seu trabalho

Estabelecimento de novos contatos

Missão do seu trabalho

Ideologia e valores da empresa

acho que tudo ali. Vivo e trabalho com as pessoas que escolhi estar próxima tem quase 10 anos. A gente que cria o clima em casa e na ninja, então, prezamos muito pela dinâmica da vivência coletiva e cuidamos dela, temos as crianças que nos trazem sempre renovação, todos sabemos o que estamos fazendo e de que lado da história estamos, como é importante onde estamos e como nos posicionamos

Posso selecionar ambiente de trabalho, clima harmonioso, reconhecimento do meu trabalho e certamente ideologia e valores

Fonte: Fernanda Bastos. Trabalho de campo, 2018.

\subsection{Quadro Resumo}

\begin{tabular}{|l|l|l|}
\hline \multicolumn{3}{|c|}{ Cultura Organizacional da Mídia Ninja } \\
\hline Área da cultura organizacional & \multicolumn{1}{|c|}{ Definição } & \multicolumn{1}{c|}{ Descrição } \\
\hline Ambiente de trabalho & $\begin{array}{l}\text { 1. RUAS } \\
\text { 2. Tenda de Comunicação do } \\
\text { ATL } \\
\text { 3. Casa Minas em Belo } \\
\text { Horizonte }\end{array}$ & $\begin{array}{l}\text { Agitado em relação às } \\
\text { atividades desempenhadas, } \\
\text { sempre estão produzindo, } \\
\text { escrevendo. Maioria das } \\
\text { conversas são diretas para } \\
\text { resolução dos problemas, no } \\
\text { entanto, falam sobre diversos } \\
\text { assuntos. Localizadas próximo } \\
\text { ao centro das cidades e com } \\
\text { fácil acesso. }\end{array}$ \\
\hline Objetivos & $\begin{array}{l}\text { Acompanhar de dentro os } \\
\text { movimentos mostrando outro } \\
\text { lado, descriminalizar pautas e } \\
\text { movimentos marginalizados e } \\
\text { criminalizados. Estimular mais }\end{array}$ & $\begin{array}{l}\text { Ao realizar uma apuração, os } \\
\text { ninjas acompanham o } \\
\text { movimento internamente e } \\
\text { participam das construç̃̃es e } \\
\text { dos movimentos ativamente. }\end{array}$ \\
\hline
\end{tabular}




\begin{tabular}{|c|c|c|}
\hline & $\begin{array}{l}\text { atores a produzir suas próprias } \\
\text { narrativas e promover guerras } \\
\text { de narrativas (contraposições e } \\
\text { mostrar o outro lado do ponto } \\
\text { de vista dos grandes veículos } \\
\text { de mídia). }\end{array}$ & $\begin{array}{l}\text { Mostram o que nunca iria sair } \\
\text { nos grandes meios de } \\
\text { comunicação como Globo, } \\
\text { SBT, Record e descriminalizam } \\
\text { movimentos. }\end{array}$ \\
\hline Valores & $\begin{array}{l}\text { Valores semelhantes aos da } \\
\text { rede Fora do Eixo e } \\
\text { compartilhados tanto pelos } \\
\text { membros da equipe orgânica } \\
\text { como pelos colaboradores }\end{array}$ & $\begin{array}{l}\text { a) descriminalizar movimentos } \\
\text { marginalizados e representar } \\
\text { causas invisibilizadas } \\
\text { b) colaboração (em rede, } \\
\text { internet) } \\
\text { c) solidariedade (economia } \\
\text { colaborativa) } \\
\text { d) comunicação como ativismo } \\
\text { e) narrativa como alavanca e } \\
\text { ferramenta para conquistas } \\
\text { públicas }\end{array}$ \\
\hline Estratégias & $\begin{array}{l}\text { 1. Estratégia de estímulo para o } \\
\text { público interno } \\
\text { 2. Diálogo constante e online } \\
\text { entre as casas; } \\
\text { 3. Retroalimentação e escola de } \\
\text { midiativismo; } \\
\text { 4. Casa coletiva; } \\
\text { 5. Moeda social }\end{array}$ & $\begin{array}{l}\text { 1. Procurar sempre estimular a } \\
\text { todos, pesquisar os problemas e } \\
\text { desenvolver projetos para } \\
\text { solucioná-los (mais estímulo, } \\
\text { mais velocidade, mais projetos } \\
\text { e mais recursos). } \\
\text { 2. Promove um time coeso que } \\
\text { sabe qual é o posicionamento e } \\
\text { de como se colocar, estratégia } \\
\text { que facilita a cobertura das } \\
\text { pautas, alta velocidade de } \\
\text { trocas. } \\
\text { 3. Permite a sustentabilidade } \\
\text { dos sistemas por meio da troca } \\
\text { de ensinamentos e } \\
\text { conhecimentos e da vivência } \\
\text { coletiva. } \\
\text { 4. A casa coletiva é onde os } \\
\text { ninjas moram e em algumas, } \\
\text { onde também trabalham. } \\
5 \text {. A moeda tem como princípio } \\
\text { a solidariedade. }\end{array}$ \\
\hline Identidade & $\begin{array}{l}\text { Gira em torno da colaboração, } \\
\text { um dos valores da Mídia Ninja }\end{array}$ & $\begin{array}{l}\text { A colaboração está presente no } \\
\text { estilo de vida nos ninjas, na } \\
\text { forma de trabalhar, na } \\
\text { economia da organização, na } \\
\text { divisão das tarefas. Além da } \\
\text { esfera interna, o relacionamento } \\
\text { com os parceiros, com os } \\
\text { leitores e usuários e a linha } \\
\text { editorial das pautas que } \\
\text { abrangem diferentes } \\
\text { movimentos e causam, também }\end{array}$ \\
\hline
\end{tabular}




\begin{tabular}{|c|c|c|}
\hline & & $\begin{array}{l}\text { sofrem influência dessa } \\
\text { identidade colaborativa. }\end{array}$ \\
\hline Processos & $\begin{array}{l}\text { Dinâmica de funcionamento da } \\
\text { rede e da vida coletiva. } \\
\text { Utilização de tecnologias: } \\
\text { a) Telegram para } \\
\text { comunicação e } \\
\text { organização da rede } \\
\text { b) Moeda social } \\
\text { c) Oficinas e universidade } \\
\text { para retroalimentação } \\
\text { da rede }\end{array}$ & $\begin{array}{l}\text { Processo de desconstrução de } \\
\text { certos vícios da criação para } \\
\text { favorecimento da vida coletiva. } \\
\text { a) grupos no Telegram } \\
\text { divididos por linguagem } \\
\text { (fotografia, vídeo, texto, } \\
\text { design, redes sociais) } \\
\text { b) tecnologia foi primordial } \\
\text { para o empoderamento } \\
\text { enquanto comunicadores } \\
\text { c) um membro organiza a } \\
\text { agenda do dia, coloca no chat } \\
\text { do Telegram da casa, pautas } \\
\text { escolhidas pelos ninjas e } \\
\text { colaboradores } \\
\text { d) moeda social surgiu para } \\
\text { suprir as necessidades que } \\
\text { estavam sendo demandas }\end{array}$ \\
\hline Estruturas organizacionais & $\begin{array}{l}\text { Modelo de funcionamento } \\
\text { horizontal, fluxo de migração } \\
\text { intenso da equipe e equipes } \\
\text { transversais }\end{array}$ & 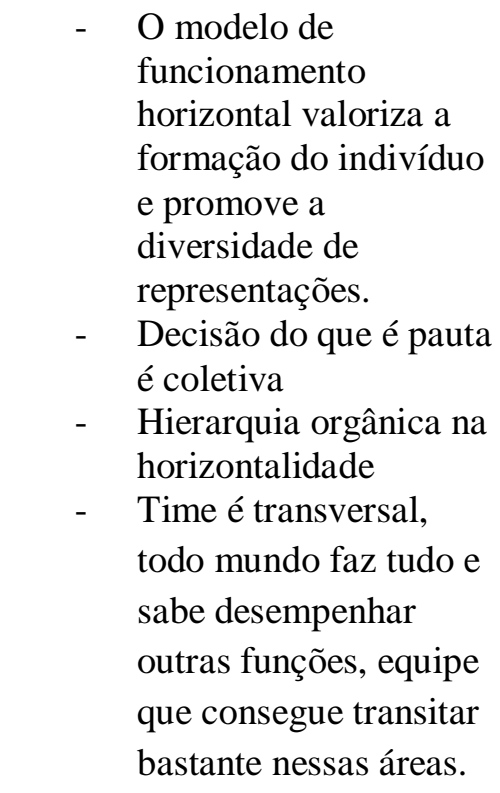 \\
\hline $\begin{array}{l}\text { Crenças estabelecidas e } \\
\text { filosofias }\end{array}$ & $\begin{array}{l}\text { Fuga da lógica mercadológica, } \\
\text { capitalista, do lucro. } \\
\text { Relatar os fatos com um ponto } \\
\text { de vista próximo de onde está } \\
\text { acontecendo. } \\
\text { Comunicação como } \\
\text { instrumento para realizar } \\
\text { contranarrativas e ter } \\
\text { conquistas públicas. } \\
\text { Linha política e ideológica bem }\end{array}$ & $\begin{array}{ll}\text { - } & \text { Vivenciar as pautas e } \\
& \text { mostrar o lado que não } \\
& \text { sai nos grandes meios } \\
& \text { de comunicação. } \\
\text { - } & \text { É uma vida, é uma } \\
& \text { missão. } \\
\text { - } \quad \text { Comunicação é poder } & \text { Informação é direito e } \\
\text { - não produto. } \\
\text { - } \\
\text { Posicionamento de } \\
\text { esquerda, defesa dos } \\
\text { movimentos sociais e } \\
\text { populares. }\end{array}$ \\
\hline
\end{tabular}




\begin{tabular}{|l|l|l|}
\hline & definida e declarada. & $\begin{array}{l}- \\
\text { Escola de midiativismo } \\
\text { criada para } \\
\text { compartilhar } \\
\text { conhecimento, mais } \\
\text { meios de comunicação } \\
\text { alternativos, melhor. }\end{array}$ \\
\hline Sentimentos & $\begin{array}{l}\text { Em relação ao local de trabalho multiplicar } \\
\text { e a função que desempenham }\end{array}$ & $\begin{array}{l}\text { Acolhimento, generosidade, } \\
\text { carinho entre os amigos que } \\
\text { trabalham, se sentem como } \\
\text { família, cuidado, liberdade de } \\
\text { ser quem é, de descobrir quem } \\
\text { é e de defender o que acredita. }\end{array}$ \\
\hline
\end{tabular}

Fonte: Fernanda Bastos

\begin{tabular}{|c|c|}
\hline \multicolumn{2}{|c|}{ Clima organizacional da Mídia Ninja } \\
\hline Elementos do clima organizacional & Descrição \\
\hline Compromisso & $\begin{array}{l}\text { Alto nível de compromisso, dedicação e } \\
\text { comprometimento dos ninjas. } \\
\text { Sabem que se algo der errado irão afetar a } \\
\text { visibilidade de um movimento e de uma } \\
\text { causa que acreditam e defendem. } \\
\text { Equipe orgânica tem dedicação exclusiva, } \\
\text { 24h por dia. }\end{array}$ \\
\hline Trabalho em equipe & $\begin{array}{l}\text { Todos opinam, decisão coletiva. } \\
\text { A relação da equipe extrapola o campo } \\
\text { profissional, são amigos. } \\
\text { Feedback construtivo e realizado de forma } \\
\text { direta. } \\
\text { Trocas de informação e conhecimento } \\
\text { constantes. }\end{array}$ \\
\hline Efetividade na gestão & $\begin{array}{l}\text { Gestores regionais nas casas e gestores de } \\
\text { cada tipo de linguagem. } \\
\text { Relação estabelecida com o líder de afeto e } \\
\text { confiança. } \\
\text { Comunicação é eficaz. }\end{array}$ \\
\hline Envolvimento dos membros & $\begin{array}{l}\text { Muitos não consideram como trabalho, mas } \\
\text { como missão de vida. Existe a mistura de } \\
\text { lazer com a vida pessoal e também com a } \\
\text { profissional. }\end{array}$ \\
\hline Motivação & $\begin{array}{l}\text { São motivados por dar reverberação que a } \\
\text { pauta não tem, são ativistas de mídia. Tem o } \\
\text { interesse tanto como participante e } \\
\text { comunicador como também ativista da }\end{array}$ \\
\hline
\end{tabular}




\begin{tabular}{|l|l|}
\hline & $\begin{array}{l}\text { causa. As conquistas públicas para os } \\
\text { movimentos movem os ninjas. }\end{array}$ \\
\hline Satisfação & $\begin{array}{l}\text { Conseguem a satisfação por terem a } \\
\text { liberdade de poder fazer a pauta que desejar } \\
\text { sem o medo de se expressar e sofrer } \\
\text { represálias. Vivem para defender a bandeira } \\
\text { que é o povo. Mostram as vozes escondidas } \\
\text { e invisibilizadas. }\end{array}$ \\
\hline
\end{tabular}

Fonte: Fernanda Bastos 


\section{CONSIDERAÇÕES FINAIS}

$\mathrm{Na}$ procura por compreender como é a cultura organizacional, os fluxos organizacionais e o clima organizacional da Mídia Ninja, o presente trabalho analisou por meio de questionários, entrevistas em profundidade e observação participante, as casas da Mídia Ninja situadas em Brasília e Belo Horizonte. Verificou-se que o valor colaboração é intrínseco à organização e perpassa pelos três objetos de análise - cultura, clima e fluxos organizacionais - para a produção coletiva de reportagens.

A comunicação é a base da empresa, presente em todos as etapas do trabalho e de vivência na casa, ela constitui a Mídia Ninja e é valorizada pelos membros por ser essencial para o estabelecimento de um clima organizacional harmônico, como também por caracterizar-se como instrumento de empoderamento para conquistas públicas. Grande parte da comunicação é realizada no meio online, por meio de plataformas como Telegram, o que facilita os fluxos de comunicação e a realização de feedbacks.

As crenças e visões sobre a cultura e o clima organizacional da empresa são consensuais entre os membros, o que mostra uma forte unidade entre as relações e ideais compartilhados pela equipe orgânica e por colaboradores. Parcialidade, guerra de narrativas, multiplicação de conhecimentos, fuga da lógica mercadológica são alguns dos elementos que constituem não só a Mídia Ninja, mas a vida de todos os membros e colaboradores.

A internet, local de desenvolvimento e expansão do jornalismo cidadão, permitiu o compartilhamento de diferentes visões e narrativas, no entanto, ainda existe a alta concentração de poder nas mãos de grandes corporações midiáticas que simboliza interesses de um grupo dominante. A Mídia Ninja e outras organizações de jornalismo independente desafiam esse status quo e representam os interesses dos movimentos e causas marginalizados e da cultura alternativa.

Alguns dos obstáculos para a realização da pesquisa foram a falta de equipe na Mídia Ninja Brasília e o fato dos jornalistas serem sempre muito ocupados. Dessa maneira, ir para a Mídia Ninja Belo Horizonte foi a solução encontrada para reverter a falta de pessoas para a realização do trabalho. No entanto, para as responderem os questionários, marcar as entrevistas, visitar as casas e conversar com os integrantes da equipe, era preciso encontrar um tempo entre as tantas pautas e eventos que os ninjas cobriam. Conciliar esse tempo com o tempo de entrega da pesquisa foi um desafio.

Esses dias de vivência ninja, de entendimento do midiativismo foram alguns dos ganhos pessoais da pesquisa. Estudar uma outra forma de fazer o jornalismo, de produção 
jornalística foi uma das maiores conquistas acadêmicas, além de saber sobre o modelo de produção explicado na faculdade, o entendimento de que não há um padrão e existem outras possibilidades é certamente enriquecedor. Em relação ao âmbito profissional, a produção de fotografias durante as marchas no papel de ninja foi uma experiência diferente e gerou um novo interesse pela área de fotojornalismo.

Por fim, acredita-se que a principal contribuição deste trabalho, é mostrar um outro modelo possível de organização de comunicação. O ambiente de trabalho mutável, perpassado por fluxos colaborativos, estratégias organizacionais condizentes com os valores de colaboração e solidariedade e por tecnologias digitais essenciais para o funcionamento da organização, mostra uma nova alternativa não só de organização, mas de transformação do ecossistema do jornalismo brasileiro. 


\section{REFERÊNCIAS}

ABREU, Alzira Alves de. Jornalismo cidadão. Revista Estudos Históricos, Rio de Janeiro, v. 1, n. 31, p. 25-40, ago. 2003. ISSN 2178-1494. Disponível em: <http://bibliotecadigital.fgv.br/ojs/index.php/reh/article/view/2185/1324>. Acesso em: 01 Mai. 2018.

ALMEIDA, Ana Luisa de Castro. Identidade, imagem e reputação organizacional: conceitos e dimensões da práxis. In Comunicação Organizacional: linguagem, gestão e perspectivas, volume 2/ Margarida M. K. Kunsch, organizadora. - São Paulo: Saraiva, 2009.

ALMEIDA, Thiago D'angelo Ribeiro, EVANGELISTA, Amanda Falcão. Tecnologias móveis, mídias independentes e coberturas de mobilizações sociais urbanas: as influências do "midialivrismo" na sociedade midiatizada. 2013. Disponível em: <http://ciseco.org.br/anaisdocoloquio/images/csm2/CSM2_ThiagoDangeloAmandaFalcao.pdf $>$

Acesso em: 11 de maio de 2018

ALMEIDA, Thiago D.'angelo Ribeiro; PAIVA, C. C. Midiativismo, redes e espaço público autônomo: as novas mídias na redefinição das relações de poder. 2014. Emília Barreto; Virgínia Sá Barreto; Claudio Cardoso de Paiva; Sandra Moura, p. 44-58.

BARBOSA, Suzana. Jornalismo convergente e continuum multimídia na quinta geração do jornalismo nas redes digitais. Notícias e Mobilidade. O Jornalismo na Era dos Dispositivos Móveis. Covilhã, PT: Livros LabCOM, p. 33-54, 2013.

BECKER, Beatriz; TEIXEIRA, Juliana Um panorama da produção jornalística audiovisual no ciberespaço: as experiências das redes colaborativas Revista FAMECOS: mídia, cultura e tecnologia, núm. 40, diciembre, 2009, pp. 44-50 Pontifícia Universidade Católica do Rio Grande do Sul Porto Alegre, Brasil.

BISPO, Carlos Alberto Ferreira. Um novo modelo de pesquisa de clima organizacional. 2006.

BRIO. Anuário de Jornalismo, 2018, São Paulo. Disponível em: < https://d335luupugsy2.cloudfront.net/cms/files/47354/1515367378Anurio_BRIO_de_Jornalis mo_2018.pdf

Acessado em: 22 de maio de 2018

BROWN, Andrew. Organizational culture. London: Pearson Education, 1998.

BRUNS, Axel. Gatewatching: collaborative online news production. Nova York: Peter Lang, 2005.

CASALI, Adriana Machado. Um modelo de processo de comunicação organizacional na perspectiva da "Escola de Montreal”. In Comunicação Organizacional: histórico, fundamentos e processos: volume 1. Margaida M Krohling Kunsch, organizadora. São Paulo: Saraiva, 2009.

CHARLEAUX, João Paulo. O que foram, afinal, as Jornadas de Junho de 2013. E no que elas deram. Jornal Nexo. 17 de jun. de 2017. Disponível em: < 
https://www.nexojornal.com.br/expresso/2017/06/17/O-que-foram-afinal-as-Jornadas-deJunho-de-2013.-E-no-que-elas-deram >

Acesso em: 09 de maio 2018.

CHIAVENATO, I. Introdução à teoria geral da administração: uma visão abrangente da moderna administração das organizações. Rio de Janeiro: Elsevier, 7. ed, 2003.

COCATE, Flávia Medeiros; PERNISA JÚNIOR, C. Estudo sobre crowdfunding: fenômeno virtual em que o apoio de uns se torna a força de muitos. Simpósio Nacional ABCiber. Santa Catarina, novembro, 2011.

CROZATTI, Jaime. Modelo de gestão e cultura organizacional: conceitos e interações. Cad. estud.[online]. 1998, n.18, pp.01-20.

DA SILVA, Rodrigo Carvalho. A transição do jornalismo - do século XIX ao século XX. 2012.

DE LIMA, Venício A. Por que a mídia tradicional tem medo da mídia Ninja? [13 de agosto de 2013] São Paulo: Pragmatismo Político. Entrevista concedida a Luis Soares. Disponível em:

$<$ https://www.pragmatismopolitico.com.br/2013/08/por-que-a-midia-tradicional-tem-medoda-midia-ninja.html $>$

Acesso em: 23 de maio

DIAS, Maurício. A mídia na ditadura. Carta Capital. São Paulo, 06 de abr. 2013. Jornal digital. Disponível em: < https://www.cartacapital.com.br/politica/a-midia-na-ditadura > Acesso em: 22 de maio

DINIZ, Lilia. O jornalismo em tempo real da Mídia Ninja. Observatório de Imprensa. 01 de agos. 2013.

Disponível em:

$<$ http://observatoriodaimprensa.com.br/imprensa-emquestao/o_jornalismo_em_tempo_real_da_midia_ninja/

Acessado em: 13 de abril

DORIA, Pedro. O futuro é logo ali em Jornalismo online: modos de fazer / Carla Rodrigues (organização). - Rio de Janeiro: Ed. PUC-Rio: Editora Sulina, 2013. - 1ª reimpressão. 216 p.

ENRIQUEZ, Eugène. Imaginário social, recalcamento e repressões nas organizações. Revista Tempo brasileiro, v. 36, p.37, 1974.

FAVRET-SAADA,Jeanne.1990.“Être Affecté”. In: Gradhiva: Revue d'Histoire et d'Archives de l'Anthropologie, 8. pp. 3-9.

FELICE, Massimo di. Massas de Mídia. Estadão, São Paulo, 11 de ago. de 2013. Disponível <https://alias.estadao.com.br/noticias/geral,massas-de-midia-imp-, 1062889 em: Acessado em: 29 de maio 
FLEURY, Maria Tereza Leme.Estórias, mitos, heróis: cultura organizacional e relações do trabalho.Rev. adm. empres. [online]. 1987, vol.27, n.4, pp.7-18.

FONSECA, Francisco. Mídia, poder e democracia: teoria e práxis dos meios de comunicação. Revista Brasileira de Ciência Política, n. 6, p. 41-69, 2011.]

FONSÊCA, Daniel. As mídias nas manifestações de junho 2013. 2013.

FREITAS, Maria Ester de. Cultura organizacional: o doce controle no clube dos raros. In Cultura Organizacional e Cultura Brasileira. São Paulo: Atlas, 1977. Página 294.

GABRIEL, Yiannis. Storytelling in organizations: Facts, fictions, and fantasies: Facts, fictions, and fantasies. OUP Oxford, 2000.

GORDON, Rich. "Implications of Convergence." Digital journalism: Emerging media and the changing horizons of journalism (2003): 57.

HARRISON, Roger; STOKES, Herb. Diagnosing organizational culture. San Francisco: Jossey-Bass, 1992.

HJARVARD, Stig. Midiatization: theorising the media as agents of social and cultural change. Matrizes 5.2 (2012): 53-91.

KOVACK, B.; ROSENSTIEL, T. Os elementos do jornalismo: o que os jornalistas devem saber e o público exigir. São Paulo: Geração, 2003.

KUNSCH, Margarida. Comunicação Organizacional: histórico, fundamentos e processos, volume 1. São Paulo: Saraiva, 2009.

LAUDARES, Humberto. O que foram, afinal, as Jornadas de Junho de 2013. E no que elas deram [junho 2017]. João Paulo Charleaux. Jornal Nexo, 17 de junho de 2017. Jornal digital. Disponível em: < https://www.nexojornal.com.br/expresso/2017/06/17/O-que-foram-afinalas-Jornadas-de-Junho-de-2013.-E-no-que-elas-deram >

Acesso em: 08 de maio 2018

LAVILLE, C.; DIONNE, J. A construção do saber: manual de metodologia de pesquisa em ciências humanas. Porto Alegre: Artmed; Belo Horizonte: Editora UFMG, 1999. Página 180.

LORENZOTTI, Elizabeth. Jornalismo século XXI - o modelo mídia Ninja. E-galáxia, 2014. Disponível

$<$ https://books.google.com.br/books?id=D8tKBAAAQBAJ\&pg=PT34\&lpg=PT34\&dq=prime ira+casa+coletiva+da+m\%C3\%ADdia+ninja\&source=bl\&ots=BVLq416ABD\&sig=5eaeAzv9 wpE6MWtWQnZC7VpHCHw\&hl=pt-

BR\&sa $=X \& v e d=0$ ahUKEwigmoa3ipzUAhWHkpAKHWo5DFoQ6AEIPzAE\#v=onepage \&q $\underline{\mathrm{f}=\text { false }}$

Acessado em: 29 de maio de 2017

MACHADO, Hilka Vier. A identidade e o contexto organizacional: perspectivas de análise. Rev. adm. contemp., Curitiba, v. 7, n. spe, p. 51-73, 2003.

MAHSAL, Prabhjot Kaur. IUP Journal of Management Research; Hyderabad (Oct 2009): 3851. 
MALINI, Fábio; ANTOUN, Henrique. A internet e a rua: ciberativismo e mobilização nas redes sociais. Porto Alegre: Sulina, 2013. 278 p.

MARCHIORI, Marlene Regina. As interconexões entre cultura organizacional e comunicação. In Comunicação Organizacional: linguagem, gestão e perspectivas, volume 2/ Margarida M. Krohling Kunsch, organizadora - São Paulo: Saraiva, 2009.

MARTINS E DE LUCA, Ana Luiza e Tânia Regina. História da imprensa no Brasil. Editora Contexto, 2010.

MEIKLE, Graham. Future active: media activism and the internet. Nova York: Routledge, 2003.

MEMÓRIAS DA DITADURA. Imprensa alternativa. Instituto Vladmir Herzog, 2012. Disponível em: < http://memoriasdaditadura.org.br/imprensa-alternativa/index.html > Acessado em: 08 de jun de 2018

MÍDIA NINJA. Perguntas frequentes. 2014a. Disponível em: < $\underline{\text { http://midianinja.org/perguntas-frequentes/ }}>$ Acessado em: 02 de abril de 2018

Quem somos. 2014b. Disponível em: < http://midianinja.org/quem-somos/ > Acessado em: 04 de jun de 2018

MORAES, Dênis. Comunicação alternativa, redes virtuais e ativismo: avanços e dilemas. Revista de Economía Política de las Tecnologías de la Información y Comunicación www.eptic.com.br, vol. IX, n. 2, mayo - ago. / 2007

NETO, Antonio Fausto. "Tchau, querida": leitura do impeachment - revista. 2016. Animus Revista Interamericana de Comunicação Midiática, v: 15, n. 30, 2016. Página 66.

OTT, J. Steven. The organizational culture perspective. California: Brooks; Cole, 1989.

PARENTE, Renata Escarião. Do midialivrismo de massa ao midialivrismo ciberativista: uma reflexão sobre as perspectivas de comunicação alternativa no Brasil. 2014.

PEREIRA, Fábio Henrique; ADGHIRNI, Zélia Leal. O jornalismo em tempos de mudanças estruturais. Texto: Porto Alegre, v. 1, n. 24, jan./jun. 2011. Página 41. Disponível em: <http://seer.ufrgs.br/intexto/article/view/19208

Acessado em: 21 de maio

PEREIRA, Fábio Henrique. Da responsabilidade social ao jornalismo de mercado: o jornalismo como profissão. Biblioteca On-line das Ciências da Comunicação, 2004.

PEREIRA, Jesus Marmanillo. CASTELLS, Manuel. Redes de indignação e esperança: movimentos sociais na era da internet. Tradução Carlos Alberto Medeiros. Rio de Janeiro: Zahar, 2013. 271 p. Horiz. antropol., Porto Alegre, v. 21, n. 44, p. 407-410, Dec. 2015 .. Disponível em: <http://www.scielo.br/scielo.php?script=sci arttext\&pid=S0104$71832015000200407 \& \operatorname{lng}=$ en\&nrm=iso

Accesso em: 01 junho 2018. 
PERUZZO, Cicília M.K. Aproximações entre a comunicação popular e comunitária e a imprensa alternativa no Brasil na era do ciberespaço. Revista Galáxia, São Paulo, n. 17, p. 131-146, jun. 2009.

PORTAL DA TRANSPARÊNCIA DO FORA DO EIXO. Carta de princípios. 2009. Disponível em: < http://foradoeixo.org.br/historico/carta-de-principios/ $>$ Acesso em: 05 de abr. 2018

POTTER, Deborah. Handbook of Independent Journalism in Journalism: Theory and Practice. Apple Academic Press, Inc. 2011. Oakville, Canadá. Página 76. Tradução nossa.

PÓSTV. Facebook. 2011. Disponível em: < https://ptbr.facebook.com/pg/canalpostv/about/?ref=page_internal>

Acesso em: 07 de maio de 2018

RAMONET, Ignacio. A explosão do jornalismo: das mídias de massa à massa de mídias. São Paulo: Publisher Brasil, 2012.

RAMOS, Daniela Osvald. Iniciativas de Jornalismo Independente no Brasil e Argentina. Revista Extraprensa, São Paulo, v. 9, n. 1, p. 114-123, dec. 2015. ISSN 2236-3467. Disponível em: <http://www.periodicos.usp.br/extraprensa/article/view/104463/107438>. Acesso em: 30 apr. 2018. doi:http://dx.doi.org/10.11606/extraprensa2015.104463.

RISÉRIO, Antonio. Duas ou três coisas sobre a contracultura no Brasil. Anos, v. 70, p. 25-30, 2006.

ROMANCINI E LAGO, Richard e Cláudia. História do jornalismo no Brasil. Florianópolis: Insular, 2007

SANTOS, Milton. Por uma outra globalização: do pensamento único à consciência universal. Rio de Janeiro: Record, 2001. Página 28.

SCHULZ, Winfried. Reconstructing mediatization as an analytical concept. European journal of communication, v. 19, n. 1, p. 87-101, 2004.

SEIGNER, Beatriz. Fora do Eixo virou um problema para a Mídia Ninja. Observatório de $\begin{array}{llllll}\text { Imprensa. } & \text { Kiko } & \text { Nogueira. } & 13 & \text { de } & \text { agos. }\end{array}$ Disponível em:

<http://observatoriodaimprensa.com.br/jornal-de-

debates/fora do eixo virou um problema para a midia ninja/

Acessado em: 20 de maio

SIQUEIRA, Paula. "Ser afetado", de Jeanne Favret-Saada. 2005. Cadernos de campo n. 13: 155-161.

DA SILVEIRA, Sérgio Amadeu. Ciberativismo, cultura hacker e o individualismo colaborativo. Revista Usp, n. 86, p. 28-39, 2010.

SODRÉ, Nelson Werneck. História da imprensa no Brasil. 4 ed. Rio de Janeiro: Mauad, 1999. 
SOUSA, Jorge Pedro. Uma história breve do jornalismo no Ocidente. Jornalismo: história, teoria e metodologia da pesquisa. Porto: Edições Universidade Fernando Pessoa, p. 12-93, 2008.

TARGINO, Maria das Graças. Jornalismo cidadão: informa ou deforma?. Brasília: Ibict : UNESCO, 2009.

TAYLOR, James R. Engaging organization through worldview. In: MAY, Steve; MUMBY, Dennis K. Engaging organizational communication theory and perspectives: multiple perspectives. Thousand Oaks: Sage, 2005.

TORQUATO, Gaudêncio. Da gênese do jornalismo empresarial e das relações públicas à comunicação organizacional no Brasil in Comunicação Organizacional: histórico, fundamentos e processos, volume 1/ Margarida M. Krohling Kunsch, organizadora - São Paulo: Saraiva, 2009.

TORTURRA, Bruno. O jornalismo em tempo real da Mídia Ninja. Lilia Diniz. Observatório de Imprensa, 01 de agosto de 2013a. Jornal digital. Disponível em: < http://observatoriodaimprensa.com.br/imprensa-emquestao/o_jornalismo_em_tempo_real_da_midia_ninja/ >

Acesso em: 03 de maio 2018

Mídia Ninja - 05/08/2013. Roda Viva. Publicado em 19 de março de 2013b. Youtube. Disponível em: < https://www.youtube.com/watch?v=kmvgDn-lpNQ > Acesso em: 02 de abril 2018

O que foram, afinal, as Jornadas de Junho de 2013c. E no que elas deram [junho 2017]. João Paulo Charleaux. Jornal Nexo, 17 de junho de 2017. Jornal digital. Disponível em: < https://www.nexojornal.com.br/expresso/2017/06/17/O-que-foram-afinalas-Jornadas-de-Junho-de-2013.-E-no-que-elas-deram >

Acesso em: 08 de maio 2018

Palestra no TEDx Liberdade. 07 de agos. 2014.

Disponível em: 〈 https://www.youtube.com/watch?v=2PlcMKNo_lU >

Acesso em: 09 de abril 2018

TUCHMAN, G. The Exception Proves the Rule: the Study of Routine News Practice. Em Strategies for Communication Research, Sage Annual Reviews of Communication Research, vol 6. Beverly Hills: Sage, 1977. Páginas 43 - 62.

VELOSO, Ellizabeth M. "A concentração da mídia e a liberdade de expressão na Constituição de 1988". Ensaios sobre impactos da Constituição Federal de 1988 na sociedade brasileira: consultoria legislativa. Brasília: Congresso Nacional, 2008.

VENTURINI E ARAGÃO, Lílian e Alexandre. Lava Jato: a origem e o destino da maior operação anticorrupção do país. Jornal Nexo. 16 de mar. 2018. Disponível em: < https://www.nexojornal.com.br/explicado/2018/03/16/Lava-Jato-a-origem-e-o-destino-damaior-opera\%C3\%A7\%C3\%A3o-anticorrup\%C3\%A7\%C3\%A3o-do-pa\%C3\%ADs

Acesso em: 04 de abr. 2018 
VILELA, Rafael. Rafael Vilela, um dos criadores da Mídia Ninja. Youtube, canal Acontecendo aqui. Postado em 28 de setembro de 2013. Disponível em: < https://www.youtube.com/watch?v=Gf5LbTbi2mg >

Acesso em: 03 de abril 2018

VIZEU, Alfredo (Org.). A sociedade do telejornalismo. Petrópolis: Vozes, 2008.

XAVIER, Aline Cristina Rodrigues. Agência pública: espaços, atores, práticas e processos em reconfiguração na produção de investigações jornalísticas. Dissertação (Mestrado em Comunicação) Universidade de Brasília, Brasília, 2015.

WOLF, Mauro. Teorias da comunicação de massa. São Paulo: Martins Fontes, 2003. 295 p. 


\section{ANEXOS}

ANEXO A - Base para entrevistas dos jornalistas

\section{Entrevista jornalistas}

Nome completo, função, tempo de experiência, idade, formação, descrição das atividades ou do papel que desempenha.

01) Como você vê a Mídia Ninja?

a) a identidade da organização

b) se fosse uma pessoa, como ela seria?

c) "quem somos" a Mídia Ninja, a identificação, você se sente parte dela? Por que você se identifica com ela (valores e ideais)?

02) Como você percebe o ambiente de trabalho da Mídia Ninja?
a) relação com os colegas de trabalho
b) o clima dentro da empresa, se sente confortável?
c) comparação com outros ambientes de trabalho que já participou?
d) vida pessoal e vida profissional se fundem? Horários invertidos da rotina normal?

03) Como são as rotinas produtivas da Mídia Ninja?
a) descreva um dia de trabalho na organização (volume de trabalho, tempo dedicado)
b) velocidade exigida no processo de apuração, produção da notícia
c) relação com a tecnologia e como afetou todo o fluxo de trabalho e organizacional
d) critérios de relevância utilizados na seleção dos acontecimentos

04) Como você percebe a estrutura organizacional da empresa?
a) relação com os líderes e fundadores da Mídia Ninja
b) a estrutura facilita o trabalho, dificulta, interfere como no clima da empresa?
c) a comunicação interna é realizada de forma eficiente com essa estrutura?
d) a divisão dos trabalhos é eficaz? Há alguma rotação entre os cargos? Há algum
cargo que você gostaria de trabalhar?

e) políticas organizacionais que você acredita que são importantes e te motivam a continuar aqui na Mídia Ninja?

05) Qual é o papel do ninja na construção da realidade?

a) o que é ser um ninja pra você?

b) Você se sente realizado? O seu trabalho é uma fonte de prazer na sua vida?

c) Quais são as suas necessidades "íntimas" e inconscientes que estão sendo satisfeitas nos seus vínculos com a empresa? Que respostas você busca? 
d) O que te leva a ser tão atraído pela empresa a ponto de realizar alguns sacrifícios que ela pede? Por meio de que mecanismos você se acomoda a esses sacrifícios? Como se dá essa acomodação?

ANEXO B - Base para entrevistas dos fundadores

\section{Entrevista fundadores}

Destinada aos membros que participaram do processo de criação da Mídia Ninja em 2013

\section{Nome completo:}

Função que desempenha na Mídia Ninja:

Tempo de experiência (fora e dentro da MN):

Idade:

Formação educacional:

Descrição das atividades realizadas na Mídia:

01) Qual era a identidade inicial, a cultura organizacional da Mídia Ninja? A Póstv foi um lab de experimentação para a Mídia Ninja?
a) São equivalentes as de hoje em dia? Por que?
b) Relação com o FdE continua a mesma? Por que?
c) A Mídia Ninja continua a mesma de 5 anos atrás? O que mudou?
d) E o que ela significa para você hoje?

02) Qual é a essência da Mídia Ninja?

a) $\mathrm{O}$ que a distingue das outras iniciativas de jornalismo independente? $\mathrm{O}$ que a torna única? O que você acha que a fez se tornar o que ela é hoje?

b) Quais são os objetivos da organização?

c) A missão, visão e valores?

03) Como você enxerga os fluxos de produção da Mídia Ninja?

a) Quais as transformações na produção da notícia nos últimos 5 anos? Levando em conta aspectos tecnológicos, políticos.

b) Quais são as influências das normas organizacionais na seleção do que é ou não pauta pela Mídia Ninja? De qual modo é realizado essa filtragem? Em grupo?

c) Há uma necessidade de inovação e renovação na empresa? Ou o que é produzido já é padrão? Em busca da última moda de filmagem ou produção de conteúdo? Ou já existe uma identidade visual construída? A empresa é flexível?

d) Fluxos de trabalho e sistema organizacional mudaram? Quais foram as principais mudanças? Jornalistas acumularam mais funções na Mídia Ninja? 
e) $\mathrm{Na}$ sociedade atual, concentração é rara, as pessoas não se demoram em uma matéria. $\mathrm{O}$ que a Mídia Ninja faz para chamar a atenção, fazer pensar e gerar reflexão?

04) Como é realizada a "gestão" dessa rede?

a) As casas são visitadas sempre por você? Como funciona esse processo?

b) As casas se conectam? Há o intercâmbio de informação e de jornalistas?

c) Qual cimento é utilizado para contribuir e sedimentar a relação entre a Mídia Ninja e os trabalhadores? E a Mídia Ninja e a sociedade? É o mesmo cimento?

d) Quais são as políticas organizacionais implantadas na Mídia Ninja que repercutiram de maneira positiva entre os colaboradores? Há o investimento em atividades culturais e sociais?

e) Quais são as inovações e soluções independentes e criativas que dão força ao crescimento da Mídia Ninja?

f) Os fundadores e líderes da Mídia Ninja retem informações só para vocês ou passam tudo para os jornalistas? O sistema de comunicação é aberto? Comunicação principal é realizada por qual meio?

05) Qual o papel da Mídia Ninja na construção da realidade?

a) Quais são as influências que a Mídia Ninja desempenha nas cidades onde tem sede e comunidades vizinhas? E no Brasil?

b) A informação construída é a realidade. Mais meios de comunicação, sociedade mais informada e decisões melhores? Você concorda? Por que?

ANEXO C - Entrevista Clayton Nobre

Nome: Clayton Nobre

Desde 2013 na Mídia Ninja, desde 2011 no Fora do Eixo

\section{1) Identidade da Mídia Ninja}

É uma rede de pessoas que se encaram como ativistas de mídia. Um pouco diferente de outras redes e coletivos que trabalham com mídia livre que todos nós nos encaramos como ativistas da comunicação e de outras causas. A comunicação é nossa causa maior porque ela é o instrumento que a gente utiliza pro ativismo, que a gente tem nas mãos. Narrativa é o essencial que utilizamos enquanto ferramenta de poder, que é uma alavanca para podermos ter conquistas públicas, mas também estamos envolvidos em diversas outras lutas e bandeiras do ativismo social. Tem pessoas que são LGBT, negros, mulheres. O próprio Fora do Eixo incentiva muito a criação de várias redes de valorização das identidades que fazem com que sejamos ativistas plenos, digamos. E a comunicação é o nosso principal mote.

\section{2) Quais são os valores que você mais se identifica?}


Temos vários e vou até falar o que fez com que nós nos uníssemos e existíssemos como Fora do Eixo, antes de formar a Mídia Ninja. Pra fazer uma introdução rápida, o Fora do Eixo é uma rede de cultura e comunicação que surgiu no início de 2005 e 2006 e tem quatro simulacros: a universidade, o banco, a incidência política e a comunicação, conhecida como Mídia Fora do Eixo. Essa última se envolveu com outras lutas e mobilizações e vimos ali um potencial de midiativismo muito forte, sendo muito reducionista chamarmos de Mídia Fora do Eixo porque não era uma assessoria de comunicação do Fora do Eixo, era uma mídia própria. A gente deu uma responsabilidade, chamamos de Mídia Ninja e a criamos em 2013. A Mídia Ninja é hoje como se fosse uma rede paralela ao Fora do Eixo, mas na verdade ela é um desses pontos, desses simulacros do Fora do Eixo. Os valores que fizeram com que a gente se conectasse, que fez com que essa rede com esses quatro simulacros pudesse existir são os valores que fizeram com que essa geração pudesse alavancar as diversas lutas e narrativas que a gente alavanca hoje, que é primeiro colaboração. Inclusive a internet é uma das mães do Fora do Eixo que fez com que nós pudéssemos nos conectar de norte a sul do país. Então, a partir do momento em que tá todo mundo conectado, um dos primeiros princípios que precisávamos era da colaboração. A partir do momento que todo mundo colabora, a gente consegue tecer uma rede que funcione de verdade. Por exemplo, pegamos a expertise de um coletivo e transformamos em uma expertise mútua, de toda a rede Fora do Eixo. A solidariedade é um outro grande princípio. A nossa economia se moveu muito a partir da solidariedade, em exemplos práticos, tipos de camaradagem, trocas de serviços e produtos, economia colaborativa. Fundamos nosso banco a partir disso, do princípio de solidariedade, esse é um valor essencial. Tem uma coisa que nem é valor, mas que faz com que a gente se movimente que é o estímulo, todas as pessoas da Mídia Ninja precisam estar estimuladas com o que estão fazendo, então todos colaboram para contribuir para que todos se sintam estimulados na função que estão desempenhando. A partir do momento que a gente aumenta o estímulo, damos mais velocidade, os projetos se movimentam mais, os recurso chegam de forma mais rápida, conseguimos comprar mais alimentos, pagar as contas. Então o estímulo é a nossa principal moeda.

\section{3) Como enxerga o ambiente de trabalho?}

Eu trabalhei durante uma semana no Diário do Amazonas, em uma redação normal, mas não consegui. Como funciona a nossa redação aqui, existem duas coisas que são principais, a primeira é essa questão de termos de espaço, de convivência e a outra questão é a hierarquia, da liderança. Um chefe de redação tem um papel que é muito diferenciado de um líder de um movimento social e o Fora do Eixo é um movimento social. Com o líder, é uma relação de confiança muito diferente, é uma relação de afeto, muito orgânica, de carinho. É impossível ter uma relação com o chefe que seja só de afeto e de carinho, no final do dia você está odiando seu chefe. Se você tem uma relação igual do seu chefe com o líder, é melhor você sair daquele movimento, se você não confia, fica complicado. Em termos de espaço, temos um modus operandi que se modifica muito a partir da nossa relação com a casa e pessoas da equipe orgânica da Mídia Ninja, que são 47 pessoas, são as que moram nas casas coletivas. Temos uma dinâmica de vivência de 24 horas, diferente das outras empresas que tem, 8 horas, há uma relação de trabalho, extremamente profissional, somos colegas de trabalho. A partir 
do momento em que temos outras relações, participar de movimento juntos, isso para a Mídia Ninja é natural porque moramos juntos, nos sentimos parte de uma família. As pessoas começaram a se relacionar dentro da rede, as crianças começaram a nascer, vira uma relação praticamente familiar, a relação é muito diferenciada. Eu acho que essa é a grande pérola da pesquisa, não é uma organização como as outras. Não quer dizer que a gente não se organize, é diferente de uma relação familiar, mas temos trocas constantes de comunicação, executamos os projetos com dedicação exclusiva à Mídia Ninja. Hoje estamos em um momento em que todos da equipe orgânica são 100\% dedicação exclusiva, 24 horas.

Não consideramos nossa atuação como trabalho, mas como vida. Não queremos entrar na lógica mercantil de separação para hora de lazer, trabalho e descanso. Acaba que essa lógica que é de sistema, que as pessoas precisam trabalhar para ter um lucro para poder se sustentar cai por terra, estamos em uma lógica superior e diferente, nem precisamos falar que estamos no trabalho. Misturamos muito o que é lazer, trabalho e descanso.

\section{4) Como é a rotina diária?}

Em uma semana de coberturas quentes, todas as noites, um dos integrantes fica responsável pela agenda. Ele organiza toda a agenda de mobilizações durante a semana inteira, de tudo que mandam no chat, das pautas culturais, políticas. Depois ele monta um documento e manda a agenda do dia seguinte no chat durante os dias com separação por horários e temas. A partir dali, colaboradores e ninjas se espalham pelas coberturas. As coberturas principais ficam com o pessoal da Mídia Ninja, as outras os colaboradores se colocam nas coberturas. Divide em foto, vídeo e redes sociais.

A equipe então de texto e vídeo cobre a pauta e mandam o material pro chat do telegram. Alguns membros ficam na base de atuação aqui no RUAS e separamos para o pessoal não se misturar tanto com a dinâmica do Fora do Eixo que, aqui em Brasília, tem duas crianças. E como aqui no RUAS é o centro de Brasília, os colaboradores já se reuniam aqui e fica mais fácil para todos. Mas, eles mandam o material no chat, e o membro que está na base e nas redes sociais, recebe conteúdo de outros chats do Telegram, revisa textos e edita as fotos que não estão editadas e pensa como será a distribuição nas mídias sociais, Instagram, Facebook, Telegram e Twitter.

O pessoal então chegava de manhã aqui na base, umas nove horas e ficavam até umas 21 horas. Depois íamos para a casa e continuamos o trabalho, realizando avaliações de como ocorreu a cobertura no dia. Como trabalhamos juntos e estamos em casa, não ficamos cada um no seu universo, consultamos uns aos outros e debatemos as questões. Como é uma sala de trabalho lá em casa, debatemos isso juntos.

\section{5) Tecnologia foi um elemento importante para Mídia Ninja?}

A internet foi essencial para formarmos a rede e nos conectarmos. Conseguimos ter um poder muito grande de conexão. Quando o FdE se formou, eram coletivos distantes geograficamente, então para poder se conectar precisávamos de nos apropriar das tecnologias da comunicação para fazermos a rede. Então utilizavamos o Irc, Orkut, fotologs e blogs como sendo os grandes canais de difusão da comunicação independente e de cultura independente. Nós como estudantes de comunicação que fazíamos. Tecnologia foi primordial para 
conseguirmos nos empoderar enquanto comunicadores e narradores. E hoje, como temos gente de várias regiões do país que colaboram, utilizamos muito a tecnologia para nos comunicarmos. Utilizamos vários chats do Telegram para podermos nos integrar e debater e comunicar diversas questões da Mídia Ninja para criar um fluxo entre nós. Erros de fluxo faz com que a gente perca muito tempo. Um exemplo é mandar fotos para grupos errados, tem um caminho que as pessoas precisam seguir, é o fluxo mesmo que utilizamos com as tecnologias que a gente tem na mão, elas podem dar mais velocidade pra gente. Tecnologias de comunicação propriamente ditas, existem várias outras ferramentas que também utilizamos, um exemplo é a moeda social. Quando a criamos precisamos de ter uma tecnologia para suprir uma necessidade. Ela pode ser replicada por outros coletivos da própria rede e não é uma ideia centralizada em um coletivo em um único espaço. As tecnologias são replicáveis, a moeda nasceu em Cuiabá, no DNA do Fora do Eixo, que foi a incubadora de várias tecnologias que a gente utiliza até hoje, moeda social, casas coletivas.

\section{6) Critérios para escolhas de pautas}

Temos uma editoria que são os temas essenciais que pautamos a Mídia Ninja, cultura, sexualidade, negritude, mobilização de rua que são temas que movem o nosso cotidiano e as bandeiras que cada um tem dentro da rede. Mídia Ninja cobre as pautas sociais e as narrativas que não ganham reverberação nas mídias tradicionais. Como o nosso berço é a cultura, todos vieram da cultura, a Mídia Fora do Eixo, antes de ser Mídia Ninja, cobria festivais independentes, escrevia sobre as novas tendências da moda, sobre artes cênicas. Pauta cultural é muito forte, vamos nos eventos de Ceilândia, no Subdulcina, articulamos rede com os produtores dessas festas aqui em Brasília. Essa é uma pauta que move muito a gente.

\section{7) A Mídia Ninja alcança o objetivo dela hoje?}

Nós temos duas grandes motivações: ou queremos dar reverberação que aquela pauta não tem, queremos que ela circule nas redes, dar luz a causa ou somos ativistas de mídia, muitas pautas tem o interesse como participante e ativista do movimento. Cobrimos e produzimos informação para explicar para as pessoas sobre as questões, nosso papel enquanto Mídia Ninja é narrar o que está acontecendo. Isso está muito no nosso sangue, somos ativistas. Outro grande papel é de ter essas conquistas públicas, não estamos só para poder cobrir necessariamente, mas estamos organicamente narrando pois fazemos parte daquele movimento. Por que a gente tá cobrindo a prisão do Lula, porque acreditamos que isso está dentro de um grande mecanismo no Brasil de injustiça social, que se a gente consegue ter uma conquista pública a partir daquela luta que estamos travando, podemos caminhar para um horizonte utópico, um horizonte mais democrático, uma luta mais primordial, pelos direitos humanos. Nossa complexidade é muito maior do que se formos só para cobrir uma pauta. Existem várias camadas de interesse nosso quando vamos cobrir uma pauta, às vezes é só para dar visibilidade e em outra porque estamos organicamente ligados aquela luta também.

\section{8) Políticas organizacionais que deram certo dentro da rede.}

Simulacros, macro políticas do Fora do Eixo. São quatro políticas essenciais que podem realizar a retroalimentação da rede. Se você quer que o seu coletivo funcione, crie 
velocidade, sustentabilidade, você precisa seguir quatro elementos para o seu coletivo atuar. É preciso uma política financeira, uma equipe, diretrizes, programas e projetos para que os recursos entrem e movimentam dentro da rede. Principalmente, planejar o que fazer quando não houver dinheiro.

É preciso pensar também na informação, que todas as pessoas se empoderem de tudo aquilo que está acontecendo no coletivo. Isso acontece a partir da passagem de conhecimento, se você tem algum ensinamento que é útil para o grupo você não vai concentrar só aquela sabedoria para você, é importante que você retroalimente o próprio coletivo, toda a rede. É preciso que a sabedoria circule dentro da rede.

Se você é um coletivo ativista, temos dois públicos, interno, 47 pessoas, que movimentam a rede. Temos ali também uma gama de parceiros, colaboradores, que a gente conecta para fora da própria rede. O pessoal dessa área de incidência política cria políticas de relação com esses dois públicos. Pra dentro da própria rede é preciso criar políticas de reuniões, é preciso criar uma estrutura organizacional que criou um organograma. As equipes precisam funcionar a partir desses quatro simulacros. Então a equipe FdE faz o desenho da própria organização, cria o organograma, divide as equipes, tem esse mapa muito claro de como ela funciona. E pra fora é a mesma coisa, quais são os nossos parceiros, temos dois parceiros estratégicos que são os indígenas e os sem-teto, que foram os dois parceiros que criamos um relacionamento forte com os movimentos sociais, a partir desses dois, criamos laços com todos os outros. Os partidos da esquerda mesmo, em algumas regiões mais com PT, outras com Psol, partido cuida muito disso.

A mídia é criar essas frentes operativas, foto, vídeo, redação, design. Essas são as principais políticas organizacionais da rede, elas são essenciais para poder se movimentar a partir desses links. As grandes frentes que a gente pode se conectar são essas quatro. Temos políticas de ações internacionais.

\section{9) Papel do ninja na construção da realidade e o que é ser ninja pra você?}

Nosso grande papel, que temos nesse caminhar de conquistas públicos dentro desse processo de redemocratização, é de poder contar história do que ocorre no Brasil. Isso só vamos conseguir avaliar daqui 20 anos. A gente constrói muito o passado no presente. E só vamos saber as consequências do que estamos fazendo agora no futuro quando pararmos para tentar entender o que aconteceu, isso é uma coisa que não estamos fazendo, não estamos contando nossa própria história. Vamos saber lendo sua pesquisa, o que as pessoas produzem sobre a gente. Estamos contando essa história que as pessoas só vão saber a partir das mídias independentes, contamos essa narrativa do Brasil contemporâneo que nem as mídias tradicionais e nem a história estão dando. Muita gente vai poder buscar a Mídia Ninja para saber sobre o impeachment da Dilma, sobre a luta indígena no Brasil. A gente está em um momento no mundo hoje de uma virada de página em que cada vez mais as pessoas estão se empoderando e apropriando das tecnologias de comunicação para poder contar sua própria história.

Quando a Mídia Ninja nasceu, em 2013, existia essa crise de mediação que foi para uma crise do jornalismo que na verdade era uma crise do papel do intermediador, do jornalista. A crise vem dessa lógica de que as pessoas estão construindo suas próprias 
narrativas, por exemplo, a Mídia Índia no ATL faz toda a sua comunicação, nós damos suporte. É o princípio da colaboração, o papel da Mídia Ninja hoje, é fazer com que essas tecnologias possam circular e ser aprendidas pelas outras pessoas também. Cada vez mais, as pessoas procuram sobre informação qualificada direto na fonte, não mais narrativas dos intermediadores. Trabalhar as organizações como espaços de formação de novos narradores, meu papel é de formador. Quem trabalha na comunicação hoje com esse perfil profissional, fazer com que cada vez mais pessoas se apropriem das tecnologias de informação.

ANEXO D - Entrevista Isis Maria

Nome: Isis Maria

Idade: 31

Função: equipe de redes sociais

Tempo de experiência: 8 anos que faz parte da rede

2011 foi morar Casa Fora do Eixo SP

Formação acadêmica: jornalismo mas não se formou

\section{1) Qual a identidade da Mídia Ninja?}

Pra mim, o Ninja é um veículo de contrainformação, a ideia do Ninja de quando ele surgiu e o que a gente busca fazer até hoje é sempre dar contra-narrativas, então é uma forma de visibilizar narrativas de minorias que são criminalizadas bastante, então, movimento dos Sem Terra, Movimento Indígena, Movimento LGBT, Movimento Negro, são mais movimentos invisibilizados e criminalizados. E da contranarrativa, geralmente você pega uma ocupação e o que aparecerá na grande mídia é movimento de vagabundos e o que buscamos fazer é ir lá pra dentro, pra mostrar que na verdade tem uma luta em cima daquilo e não é só uma baderna.

\section{2) Quem é a Mídia Ninja?}

Militante bem parecido com os que temos hoje em dia. Alguém que não venha necessariamente de movimentos, tem muita gente do Ninja que veio do movimento estudantil, era de DCE, mas tem gente que chegou no Ninja e veio por outro viés, gostava e enxergava essas pautas mas não tinha o desejo de trabalhar com a grande mídia. Se ela fosse um militante, seria um militante assim, alguém que se interessa pelas pautas da esquerda, pelo movimento social, que gostaria de visibilizar esse movimento. Não necessariamente alguém que mora em uma ocupação mas alguém que entende que ocupação é um movimento de luta, alguém que não é LGBT mas que entende que é uma causa que merece ser visibilizada e merece respeito.

\section{3) Quais valores você se identifica na Mídia Ninja?}

O fato de poder dar voz e descriminalizar. Eu, particularmente, venho da periferia de uma cidade pequena. Então esse lance de morar à margem e da criminalização, ser negra e conviver perto de ocupações, eu já convivia com isso e com o estigma que as ocupações tinham. Chegar hoje e poder mostrar que essa "galera perigosa" é uma galera que não tem grana pra morar, que tem que escolher no final do mês entre comer e pagar o aluguel e que 
estar ali em um local abandonado e dar função social para aquilo faz com que isso seja o tipo de coisa que quando eu estava na faculdade, não era o tipo de coisa que eu pensava em fazer, mas é muito mais legal estar nesse lugar hoje do que o que eu almejava quando entrei na faculdade 15 anos atrás. Até por vir desse lugar de periferia, eu acreditava que ia entrar na faculdade, ser jornalista e iria trabalhar em um grande veículo e teria muito grana e sairia daquela condição. Conseguir então hoje dar voz àquelas pessoas que não conseguiram sair dessa condição e mostrar o que acontece e que elas não são os criminosos que dizem que elas são é uma das coisas mais legais de estar nesse lugar. Também o que a gente faz hoje, principalmente porque trabalhamos muito com internet, rede, conexão talvez são coisas que outras pessoas também possam fazer, transmissão ao vivo, cobertura de um ato. Mas acompanhar de dentro essas coisas, dar continuidade também pra isso é uma das coisas que o Ninja faz de diferente e que é legal. Acompanhar de perto as ocupações, os movimentos, participar da construção dessas coisas, dos atos e das ocupações desde o início, não são todos os veículos que fazem a cobertura disso e conseguem atingir.

\section{4) Rotina diária e de cobertura}

Temos pessoas com funções bem específicas e algumas que são mais móveis. Por exemplo, o Oliver é fotógrafo, então a maioria das vezes ele cobre com foto, manda elas em tempo real e sempre vai mandar um texto junto, gravar um vídeo e transmitir ao vivo. Diferente de um fotógrafo de algum outro veículo que vai ficar 15 minutos ali, fazer umas fotos e ir embora. Estamos mais acostumados a acompanhar as coberturas em um ritmo, então ele vai fazer foto que é a função maior, mas vai também gravar vídeos, realizar entrevistas, mandar parágrafos para contextualizar. Quando é uma cobertura maior, realizamos as reuniões, definimos quem vai desempenhar cada função e dividimos os times. Se a minha função, por exemplo, for ficar na base, vou ficar no computador fazendo redes sociais e não vou sair pra fazer foto, mas isso a gente define de acordo com cada cobertura. E os colaboradores que chegam, analisamos a expertise deles e distribuímos onde temos demandas. Tem gente que é mais multiuso e realizam várias funções. São poucas as pessoas que nos procuram que escrevem ou fazem gestão de redes sociais, a maioria são fotógrafos, videomakers, pessoal interessado na transmissão ao vivo. Acabamos definindo isso em reunião de pauta e como é melhor distribuir.

\section{5) Reuniões presenciais ou mais online?}

Realizamos algumas reuniões presenciais mas utilizamos mais o grupo no Telegram. Temos um sistema nosso da gestão, tem a editoria do Ninja, a equipe de redes sociais, grupos por linguagem e grupos regionais que são os colaboradores. As cidades que tem casa tem os gestores das regiões e nos dividimos para cobrir as outras. Aqui em Minas, chat de Minas. Brasília, chat DF e Centro-Oeste. Norte, Nordeste nos dividimos para cobrir. Como Brasília temos a casa que acompanha, a gente monta esse time da comunicação da casa. Acompanha a agenda, sugestões de agendas e pautas e toda noite mandamos o que vai acontecer no dia seguinte o que já temos de pauta e o que vai rolar. Brasília especificamente mandamos a agenda da Câmara e do Senado, atividades nas regiões administrativas e mandamos o que tem de atividade no grupo a noite. Então a galera vai se colocando, distribuindo as pautas e no dia 
seguinte cada um vai para as coberturas que se comprometeu a fazer e manda fotos, vídeos e texto pelo telegram. E isso vai acontecendo assim no fluxo, hoje com a greve dos caminhoneiros, por exemplo, a galera tá mandando link que está achando, foto e vídeos espontâneos enviados pela população, mas esse fluxo é feito mais pelos chats das cidades, das regionais. A partir disso filtramos tudo o que foi recebido e mandando para a editoria e decidindo o que vai postar ou não. Não ocorre reunião de pauta diária, mas por exemplo, em Brasília fizemos uma grande reunião com os colaboradores no início do ano, depois fizemos algumas específicas de coberturas maiores, Outros Carnavales, ATL e vamos fazendo reuniões com as pessoas, mas a comunicação diária se dá mais online.

\section{6) Avanço das novas tecnologias.}

Em 2013 utilizávamos mais o WhatsApp, mas esse trabalho de rede, começou com o Irc, ferramenta de bate-papo online, estilo bate-papo Uol, mas de software livre. Depois existia um chat grande no MSN, tinha o chat geral do FdE e os das linguagens, música, foto. Usamos Hangout do Google para fazer reuniões online e vídeo chamada e tinham as listas de email para o fluxo do dia, cada linguagem tinha sua lista de email. Skype também montávamos grupo para reuniões, quando são muitas pessoas a qualidade da chamada não é boa, mas pode haver a troca de mensagens digitadas como um chat mesmo. Criamos também grupo no Facebook, que antigamente, já criava automaticamente um chat de mensagens no messenger, então tinham os chats regionais de cada lugar. Então veio o WhatsApp e hoje em dia utilizamos o Telegram. Para esse fluxo de envio de material, fluxo diário, das coisas do Ninja, é tudo por telegram. Montamos grupos das coberturas no Telegram. Recebemos pautas e informações pela fanpage do Ninja e pelo email também e muita gente manda por inbox para o Ninja. Mas para esse fluxo de cobertura, de times de tempo real é Telegram.

\section{7) Como enxerga o clima dentro da organização, como você se sente aqui?}

Desde que a gente começou com o coletivo lá em Baurú e até hoje, uma das coisas que sempre procuramos trabalhar no ninja é sobre a dinâmica. Essa parte de fazer as coberturas, acompanhar as redes do Ninja em tempo real, por mais que seja às vezes cansativa e trabalhosa, por ser um volume grande, uma cobertura muito extensa, é a parte mais fácil. $\mathrm{O}$ dia a dia, da dinâmica é o que a gente mais trabalha. Todos vem de uma criação com a família e em um determinado momento você vai trabalhar, ter sua grana, ter suas coisas, ter sua casa e criar a sua família. Você já vai com uma criação e com uns vícios e algumas coisas que quando você cai no processo coletivo você tem que desconstruir. Juntamos todos os vícios de todos e precisamos chegar em um nivelamento do que é ok para cada um. É preciso ceder em algumas coisas e avançar em outras. Isso faz com que o processo seja rico, você vai desconstruindo alguns preconceitos e avançando em outros pontos. Acho que o clima é muito de acordo com o que a gente faz e acredito que todos têm essa consciência de que a dinâmica é imprescindível para que todos fiquem confortáveis. Não adianta cobrar para que um cara se desconstrua de algum machismo enquanto as mulheres não avançam nos apegos delas com algumas coisas, e é isso que buscamos trabalhar bastante. E pra gente conseguir trabalhar isso, tem que ter muito diálogo, muito abertura, muita confiança. Acho que conseguimos fazer que o ambiente seja propício pra isso, pra que sejamos abertos um com outro. Nos colocamos 
nesse lugar de ouvir bastante, apontar as coisas pro outro e colocar sempre o que está incomodando para que aquilo não vire uma novela, mas tenha sempre o tamanho que tenha que ter. Não chega a ser igual uma organização formal, patronal, mas temos as pessoas que são gestoras de alguma coisa. Aqui em Minas, Tales e Irlana são gestores da Casa Minas, estão aqui há mais tempo, são pessoas que acompanham os processos dentro da casa há mais tempo. Apesar deu ter bastante tempo de rede, quando eu chego aqui eu não saio fazendo as coisas sem falar com o Tales. Ou porque tem muitas coisas que ele já fez e não deu certo, ou estão esperando algo acontecer para poder realizar tal ação. Ter essa liberdade para fazer esses apontamentos acontece muito aqui. Conversamos muito um com o outro, sempre tendo essas pessoas que estão no lugar de observar o todo, de gestor, conseguem ver o processo inteiro e não só um pedaço dele. Esses gestores têm também a missão de cuidar para que as coisas não se percam, tem cuidado com o todo, com a manutenção de deixar todos confortáveis, nivelados e tranquilos para realizar suas funções. A dinâmica rolando, as pessoas confortáveis se sentem estimuladas para o que estamos fazendo, então isso faz com que consigamos estar contentes para trabalhar, pra fazer as coisas que precisamos fazer, isso é uma das coisas que conta mais até no Ninja, eu acho, tem muito haver com o estímulo. Estar estimulado em acompanhar alguma coisa faz com que tenhamos vontade de estar naquelas pautas, se não, não teríamos muito o porquê.

\section{8) Estrutura organizacional}

Sempre tentamos organizar organogramas, dividindo em frentes de trabalho, linguagens, sempre pensando que teria alguém para gerir aquilo para aquilo funcionar. Desde o FdE, que tinha a distribuição, o banco, a comunicação e a logística. Dai existiam as linguagens que eram música, cinema, teatro. Se não houvesse a divisão dessas frentes e o gestor de cada uma dessas frentes, elas não iriam caminhar. Os projetos, esses gestores são flutuantes, então em determinado momento, o Tales, gestor da casa Minas, vai para Brasília e lá ele já não é mais gestor, lá tem as mulheres que já estão nesse processo. Então ele chegaria em Brasília não sendo gestor de lá, mas sendo gestor da música que é uma das coisas que ele toca. Diferente por exemplo de uma empresa, que o vice-presidente é o vice-presidente e não será outra coisa menor quando ele sai da sala de vice-presidente e entra no refeitório. Aqui, quando você é gestor de uma casa e vai pra outra, você não é o gestor da outra casa, você vai ser base das pessoas naquela casa, mas você vai continuar sendo gestor das linguagens que você domina dentro do processo. Diferente dessa estrutura quadrada, acho que temos essa maleabilidade aqui e que se a pessoa começa a desenvolver, se apaixonar e se estimular por alguma linguagem, a pessoa se torna gestor daquilo também. Ele não precisa que alguém ligue pra ele e comunique que ele está gerindo essa área, se ele está conseguindo articular, organizar rede, fazendo aquilo, encaminhando, trazendo feed, ele vai automaticamente se tornando gestor daquilo. Na rede existe a maleabilidade das pessoas serem mais gestoras em alguns processos e mais base em outros e isso flui. Em Brasília, o time de lá é diferente daqui, somos mais mulheres e tem as crianças, Carol e Le gestora da casa, Lou é gestora do banco, Clayton com a universidade, eu e Oliver com a comunicação e eu e a Lou com as crianças. Isso varia de casa pra casa, como cada casa apesar de ser uma casa coletiva e ter muita coisa em comum do tec, de como funciona a casa, elas tem projetos diferentes, quantidades e pessoas diferentes, 
então as gestões mudam também de acordo com isso. Mas no Ninja em si, temos as divisões de linguagem, foto, tv, redes, colunistas, redação. E dai temos a editoria do Ninja, que são as pessoas que estão desde o começo pensando o Ninja e não necessariamente são as pessoas que estão escrevendo, mas que sugerem pautas, participam das discussões, debates. São pessoas que vão opinar sobre a produção de conteúdo e como iremos se posicionar naquilo, porque eles fazem parte dessa construção. O que nos diferencia de outros veículos também é isso. Por exemplo, a editoria da Folha é formada por profissionais que fazem parte da redação e a gente por ser um corpo muito maior e uma rede que funciona com base na colaboração, do entendimento de que todos são importantes nesse processo, a gente sabe que mesmo que eles não escrevam, eles estão na construção do Ninja há 20 anos, desde quando era Cubo, lá em Cuiabá em 2006. É um processo muito maior do que só um time que senta e escreve. A nossa editoria é composta por outras figuras além dos repórteres só do Ninja. Dai temos os gestores de linguagem, gerem desde a cobertura, até a postagem. Eu tenho autonomia para mexer no flickr, postar no instagram, mas eu sempre vou falar com eles sobre as coisas que estão relacionadas com as suas linguagens. Sempre conversa com eles sobre, passar as informações, pedir referências, dicas. Isso de conversar, ter fluxo um com o outro, tá mais ligado ao que as pessoas que estão na gestão das linguagens ficarem cientes do que está acontecendo do que algo mais como se reportar para o patrão. Se houver algum problema, eles sabem o que está acontecendo. Temos então as figuras de gestão dentro das linguagens e dentro do time de redes também, pois estamos desde o começo da Ninja, estão acompanhando, tem várias experiências.

\section{9) Decisões organizacionais que estimulam os membros a ficarem mais na empresa?}

Temos toda essa estrutura de gestão, mas acho que temos uma autonomia e liberdade que é muito diferente de qualquer outro lugar e isso é uma das coisas legais porque você tem uma liberdade para trazer temas, diversidade de editorias que acompanhamos, óbvio que política, nesse momento é o mais importante, mas temos liberdade para falar sobre LGBT, movimento negro, cinema, maternidade, legalização, direito a cidade. Acho que em uma redação comum, você ia ter muito claro as pautas que você tem que cobrir. Temos lógico, nossa linha política e ideológica que seguimos como todos os outros, mas temos isso muito claro, diferente do mito da imparcialidade, que você precisa ser isento. Nós sempre tivemos muito declarada qual é a nossa posição e a liberdade de saber que você pode falar sobre aquilo sem represálias ou medo de rabo preso é bom. A liberdade de podermos debater entre nós os assuntos. As coberturas de Brasília são muito diferentes das de BH que são diferentes das de São Paulo, mas como conversamos bastante, temos um time coeso e a gente sabe do nosso posicionamento e de como nos colocamos, é mais tranquilo para poder falar e cobrir. Conseguimos realizar a conexão das cidades, mesmo sendo muito diferentes, e manter uma linguagem parecida por conta disso. Essa tranquilidade de trazer as pautas, de conseguir transitar por muitos assuntos, não ser um lugar quadrado, essa flexibilidade, essa liberdade de conseguir trazer muitas coisas para dentro pra discutir e ter outras rotas para levantar mais debates por meio dos parceiros. Essa liberdade e tranquilidade de poder falar sobre muitas coisas. 


\section{0) Papel do ninja na construção da realidade?}

Um dever do ninja, um papel nosso dentro da atualidade, é conseguir ajudar a descriminalizar movimentos e conseguir trazer outras narrativas. Temos o poder de estar dentro desses lugares, de estar na construção junto com essas pessoas, e de conseguir mostrar isso diferente dos outros veículos. Poder ir em uma ocupação, estar dentro e ser aceito lá e conseguir passar aquilo pras pessoas e mostrar o que acontece nesses lugares e conseguir ajudar a descriminalizar isso, é o papel mais importante que podemos desempenhar. Não existe uma coisa que fazemos exclusivamente, há cinco anos atrás, transmissões ao vivo eram sempre relacionadas a Mídia Ninja, hoje em dia, qualquer um pode realizar. Isso já não é mais um diferencial pra ninguém, mas essa manutenção, essa proximidade com o movimento social, esse lugar de onde a gente veio, de conseguir estar dentro, participar e construir junto e não ser um oportunista que vai cobrir aquilo e nunca mais vai voltar, eu acho que isso é parte importante do que a gente faz, de conseguir estar sempre na base desses movimentos e dessas pessoas, de conseguir levar a luta delas pra fora da bolha delas, não representando eles do mesmo jeito que são retratados há mais de uma década, como vândalos. Falar dos movimentos sociais e movimentos populares sem uso de termos pejorativos, isso é o mais importante que podemos fazer hoje.

\section{1) Narrativa que a Mídia Ninja construiu na sua vida?}

É mostrar possibilidades, quando eu fui morar em Bauru para fazer faculdade, tinha um pouco disso de sair do meu local e fazer algo diferente do que muita gente fez. Quando começamos com o coletivo e entramos pro Fora do Eixo, fui descobrindo outras possibilidades para além de ser jornalista e comunicadora. Ai conseguir chegar no Ninja, estar cobrindo as coisas que eu cubro, acompanhando as coisas que eu acompanho, escrevendo sobre esses temas, acho que foi essa narrativa, de conseguir me mostrar que existem outros caminhos pra gente fazer coisas que a gente gosta do que só necessariamente aquele retão tradicional que é sair de casa, fazer faculdade, ter um diploma e um emprego estável.

ANEXO E - Entrevista Talles Lopes

Nome:

Thales

Lopes

Formação acadêmica: Ciências Sociais na universidade de Uberlândia Entrou em 2005 no Fora do Eixo, está na casa Mídia Ninja desde 2012 Papel na Mídia Ninja: editor e gestor da casa Mídia Ninja Belo Horizonte

\section{1) Qual é a identidade da Mídia Ninja de hoje e de 2013? Houve mudanças?}

Acredito que não houve uma mudança de identidade, a Mídia Ninja nasce de um processo anterior, existia um acúmulo de 10 anos de experiência de mídia livre no Brasil e de experiência de criação de um núcleo de mídia livre que era o Fora do Eixo. Tanto do desenvolvimento prático de uma série de ações voltadas para a comunicação, como coberturas colaborativas dentro dos festivais, onde surgem experiências como essa de juntar várias pessoas durante um final de semana. Assim, há o início da construção de metodologias do trabalho colaborativo em comunicação, as primeiras transmissões ao vivo, webrádio, 
transmissões com vídeo. Ao consolidar as casas como territórios, onde as pessoas vivem, existe a possibilidade também de convidar parceiros, há assim debates e também a experiência da PósTV aflora. A rede identificou a comunicação como um dos eixos prioritários, há a criação de metodologias de gestão de conteúdo, uso das novas ferramentas e das novas tecnologias. Houve um processo muito intenso que a Mídia Ninja de certa forma foi uma síntese de toda essa construção. Ela nunca foi uma tentativa de jovens que vendo as transformações resolveram criar um veículo, não, existiram 10 anos de uma trajetória, de um acúmulo de experiência que sintetizaram na criação da Mídia Ninja. Como ela já é lastreada pra um modo de vida que o Fora do Eixo desenvolveu, não há alteração de identidade porque existe uma forte organicidade, relações de confiança estabelecidas por um longo período, tanto dessas pessoas que vivem na casa e escolheram viver dessa forma como também uma definição do que seriam alguns princípios e valores que a Mídia Ninja defende. Desde quando ela surge em 2013, um dos primeiros debates que existiram foi dela assumir um lado, de não ter problema em defender determinados pontos de vista a partir de um conjunto de valores que acreditamos. E esse conjunto de valores não está só em uma carta, ele tá enraizado nesses espaços que a gente construiu para poder viver e nesse modelo de vida que temos, que é compartilhado, colaborativo, comunitário. A gente acaba expressando na nossa linha editorial, para além de uma visão de mundo, um modo de vida também. Acho que isso não mudou, essa é a identidade da Mídia Ninja. O que acredito que aconteceu, coincidentemente nesse processo de construção da mídia é que temos passado por processos políticos muito intensos no Brasil e nós não podemos abrir mão de se posicionar e de acompanhar tudo isso.

\section{2) Qual é a essência e os valores enraizados da Mídia Ninja?}

Colocando no plano macro, defesa dos direitos humanos, da democracia, a partir de uma construção que vem da cultura da comunicação, é expresso nas nossas pautas. Nossa linha editorial está conectada a movimentos sociais que lutam por justiça ou por democracia ou que lutam por direitos humanos identitários, a luta feminista, a luta do movimento negro, combate a LGBTfobia, combate ao racismo, ao machismo. Valores universais são esses. E a essência é traduzida no modo de vida das pessoas que construíram o processo. É uma perspectiva de vida comunitária, as pessoas vivem juntas, compartilham desde a criação dos filhos até a comida, até a organização do espaço, a limpeza dos lugares. Talvez não consigamos transformar a realidade que questionamos, se não conseguirmos criar outros modos de vida, outras subjetividades. Se continuarmos operando uma lógica individualista, consumista, de distanciamento e de separação da relação do homem com a natureza, de preconceitos, se não buscarmos igualdade, se isso não for construído como uma coisa muito real e prática, teremos dificuldade de enfrentar. O que fizemos foi isso, criamos um ambiente onde na nossa vida cotidiana, nas nossas práticas somos orientados pelos valores que acreditamos que devem orientar a sociedade como um todo. De certa forma, ao pensarmos na essência, é uma essência muito mais ligada a forma de organização das comunidades tradicionais, dos povos indígenas brasileiros, da resistência quilombola, do que um modelo ocidental de organização coletiva a partir de interesses, que geraram partidos, sindicatos.

\section{3) O que a Mídia Ninja traz de diferente, no que ela inova?}


Esse debate sobre a essência é o que trazemos de mais diferente. Não reproduzimos um modelo de organização tradicional de trabalho, de remuneração, de contrato entre as pessoas. Talvez por isso a Mídia Ninja conseguiu o lugar que conseguiu, talvez por isso, conseguimos uma adesão das pessoas com trabalho colaborativo que elas entendem que aqui existe um tipo de administração das relações que não são as relações de mercado. Isso talvez seja a grande diferença, a forma como administramos nosso tempo, como nos relacionamos, se tivéssemos tentado abrir mais uma empresa de mídia, talvez não teríamos alcançado os resultados que conseguimos ao partir de um processo que é diferente.

\section{4) O que mudou nos fluxos organizacionais durante esses cinco anos de existência?}

Quando surgimos, em 2013, através desse processo de efervescência, com uma expectativa positiva de como esses lugares nas redes sociais poderiam servir para boas lutas ,bons combates de narrativas, boas transformações e para orientar uma democratização da comunicação. Acho que naquele momento tinha um sentimento muito positivo, uma esperança em relação as transformações e que nós de alguma forma conseguirmos encarnar. É possível ter uma nova mídia. Esse sentimento a Mídia Ninja carrega desde o início, desde que lá em 2013 conseguimos pautar o Jornal Nacional e fazer o jornal - no caso da prisão do Bruno - fazer uma matéria colocando o Bruno como um vândalo teve que desmentir e mostrar que na verdade era um P2 que começou a manifestação e que o Bruno era inocente. Era um momento de muita esperança. Posteriormente, com o próprio programa Roda Vida, onde o novo jornalismo e o velho jornalismo se encontraram, acredito que foi um fator que conseguiu problematizar várias questões. Ajudamos a evidenciar a crise de representatividade na mídia que tenta se colocar como imparcial, acima do bem e do mal, mas que defende interesses sim. Isso começou a ser mais questionado na sociedade, do mesmo jeito que temos crise de representatividade na política temos também a crise de representatividade na mídia. Isso foi um dos fatores que 2013 mostrou e esse processo não acabou, ele continua. Acredito que nós encarnamos um fluxo de produção de conteúdo e de distribuição de conteúdo que dialogava com essas transformações no mundo e com a dinâmica que as redes sociais traziam. Do tempo real. Fomos um pouco pioneiros na dinâmica da foto que a velocidade subia enquanto as coisas estavam acontecendo. Isso trouxe uma nova dinâmica para essa produção de conteúdo e o nosso ao vivo, acabou obrigando de certa forma o próprio jornalismo a rever algumas coisas. A manifestação que só era coberta pelo helicóptero e hoje vemos frequentemente, na Globo News, um monte de link ao vivo de celular, os repórteres entrando ao vivo, mostrando que estão mais próximos, principalmente quando há o interesse na pauta. Quando não tem o interesse a distância continua sendo a do helicóptero. Acho que acabamos provocando muito esse ecossistema, não provocamos só na relação com a tecnologia, mas também nessa coisa do que está por trás do modo de fazer a matéria. Provocou os jornalistas também, você vê muita gente que pode compartilhar a visão de mundo que compartilhamos, mas que pelo fato de estar em grande veículos ou pelo fato de vir de uma formação acadêmica dentro do jornalismo olha pra nós com uma certa desconfiança se questionando "quem é essa galera?", “como vão se sustentar?", "como isso vai gerar um mercado que vai conseguir sustentar os jornalistas do Brasil inteiro?". Esse nunca foi nosso objetivo, nosso objetivo é justamente fazer essa provocação sobre o modo de vida. Acredito que acabamos mexendo bastante com 
esse ecossistema da comunicação brasileira, positivamente, para gerar novas experiências. Logo após vem os Jornalistas Livres que consolida como rede e se distribui no Brasil e utiliza tecnologias de gestão de rede e de pessoas que são semelhantes às da Mídia Ninja. As primeiras reuniões dos Jornalistas Livres em Belo Horizonte ocorreram na casa Fora do Eixo, da Mídia Ninja, convocadas por nós, não tem concorrência, trabalhamos com colaborativismo. A dinâmica de redes sociais, de internet, descentraliza, tudo bem que ela centraliza em plataformas como Facebook, Google, mas na busca a informação, no acesso a informação, você pode se informar tanto pelo Jornal Nacional como por aquele youtuber que você gosta. Acreditamos que a fase da mídia de massa tá sendo superada por uma fase de massa de mídias e apostamos nisso. Quanto mais mídias independentes surgirem pelo nosso campo, com disposição de disputar essas narrativas, disputar essa informação, essa formação da opinião, melhor.

\section{5) Como funciona as escolhas de pauta na Mídia Ninja Belo Horizonte e como os fluxos organizacionais influenciam a produção da notícia?}

Por mais que existe o peso da linha editorial política de Brasília para os outros lugares, a gestão e a construção dessas pautas acaba não sendo muito diferente. Temos nossas redes estabelecidas de colaboradores da Mídia Ninja, temos o chat do Ninja Minas Gerais com pessoas de cidades diferentes de todo o estado e é o local onde as pessoas podem encaminhar os conteúdos e as pautas que elas identificam. Além disso, acompanhamos movimentos e acabamos construindo relações com os mesmos. Então há um lado do nosso radar e da identificação do que é pauta, igual agora, greve dos caminhoneiros e todos estão atentos a isso. Ao mesmo tempo, já existe uma referência, chega muito coisa. Apuramos se é verdade ou não para não dar bola fora, mas construímos uma relação de confiança com essas pessoas que normalmente quando elas nos enviam pautas elas já sabem o que vai acontecer e necessitam dessa cobertura. No momento, são movimento e grupos que não conseguem ter outro espaço e isso foi uma coisa que identificamos depois de começar a fazer e não sabíamos que o abismo era tão grande. Como normalmente existe um bloqueio por parte dos veículos, então essa existência de veículos como Mídia Ninja, Outras Palavras, Jornalistas Livres, Fórum, como elas são vistas de forma valiosa por essas pessoas que estão nesses lugares fazendo essas lutas. Então chega muita coisa mesmo. A partir do momento que chegam existe um fluxo, chegam nos nossos chats regionais do Telegram, Whatsapp, inclusive em conversas privadas. Encaminhamos pro chat regional que tem um filtro que vai para editoria nacional que posta pelo grupo de redes sociais.

Como nos organizamos a partir dessas relações de confiança, isso também acaba refletindo na construção lá fora. Exemplo: movimentos que fazem ações incisivas, Movimento dos Trabalhadores sem Teto vai ocupar uma área improdutiva para buscar moradias para as famílias. Normalmente essas ações são sigilosas, construídas com um certo cuidado, não podem vazar antes. Como temos essa relação de confiança, acabamos nos envolvendo, tendo a informação e quando a coisa acontece já estamos lá porque politicamente já existem essas relações de confiança. Depois que a coisa aconteceu é que os outros veículos de comunicação vão saber, então acho que as relações de confiança dão também um acesso às ações que gera uma produção de conteúdo diferenciada que outros veículos talvez não tenham 
porque justamente não tem essa mesma confiança por parte dos atores que estão construindo aquela relação que é a notícia.

\section{6) Existe a necessidade de inovação e renovação da Mídia Ninja?}

Sempre terão pontos para inovar e desenvolver. Hoje começamos a pensar em relação a tecnologia de inteligência artificial, teríamos condição através do uso de bots de termos um fluxo com muito mais pessoas em supergrupos de Telegram que é a tecnologia que utilizamos para fazer esse fluxo de organização da rede. Se você tem ali uma figura que consegue responder, tirar dúvidas, iria facilitar que falássemos com mais pessoas do que hoje tendo que cada um tendo que responder e construir. Esse é um dos lugares que estamos mirando e começando a dedicar estudos. O resto são desdobramentos que fazem parte de um processo que está em curso e aprimoramento, a ideia da TV Ninja, essa produção audiovisual, onde isso vai dar, dos vídeos de internet para documentários para telas de cinema, acho que é um processo que já está acontecendo e que já temos ferramentas e metodologias de gestão de pessoas e de conteúdo que podem gerar isso. Se ainda não acontece, é porque devemos lidar com uma conjuntura de um país que está desabando e não podemos abrir mão de determinadas lutas e de estar em determinados lugares. Temos que estar acompanhando o que está acontecendo, temos que estar na base desses movimentos sociais todos, de denúncia, mas com um pouco de atenção que temos dado a essa questão, acredito que teremos essa experiência da TV Ninja, de documentários Ninja, de filmes Ninja, de uma Netflix Ninja, de coisas que possam surgir nesse sentido. Há também o eterno desafio da criação de novos ambientes nos quais as pessoas possam se encontrar nesse mundo virtual, quando falo da programação, da inteligência, muito se fala até quando o Facebook vai ser o único lugar de debate. Será que vai surgir alguma rede social nova conectada a essas pautas e essas agendas que desenvolvemos, não pode surgir, não pode vir. Ainda tem muito pra inovar, muito pra Mídia Ninja fazer.

\section{7) Como funciona a gestão da casa da Mídia Ninja BH e qual é o cimento que sedimenta a relação dos colaboradores e também da equipe orgânica?}

O que caracteriza essa gestão interna, são essas relações de confiança e identificação com aquilo que a gente defende e acredita. Ninguém está aqui obrigado, por contrato. São os valores, primeiro a pessoa tem que se identificar com isso. Ela tem que estar disposta a fazer parte desse processo de construção desse modo de vida. Isso determina essa relação interna, as pessoas vem pra cá porque querem. Existe um nível de dedicação que está relacionado a isso, o compromisso, se a pessoa às vezes se dispõe a trabalhar mais ou a acordar cinco horas da manhã porque tem uma pauta que tem que acompanhar é porque ela tem um compromisso com aquilo que é pra vida dela. Não é porque o Thales tá pedindo. Isso facilita a cobrança interna, não precisa ficar cobrando, cada um tem a consciência de que se ele não fizer vai prejudicar os parceiros e movimentos. No cotidiano a organização é como organizar tudo, tem que lavar banheiro, arrumar a comida, tem o cronograma, pessoas compreendem quando alguém não pode cuidar da casa por precisar se dedicar bastante durante um dia para uma pauta. A pessoa que tá na rua cobrindo a pauta e a pessoa que tá fazendo o almoço tem o mesmo valor. São ações que complementam e dão suporte para que isso como um todo exista. Não há a criação de um ambiente de meritocracia, de qualificação. Com os colaboradores e 
com parceiros externos, existe uma identificação com esse processo, as pessoas conhecem, sabem como as pessoas que estão aqui dentro vivem, conhecem a forma como monetizamos as questões relacionadas à Mídia Ninja. Processos são abertos, trabalhamos com colaboração e doações, os recursos são utilizados para manutenção disso daqui. Caso entrem mais recursos, são destinados para estrutura, compra de equipamentos, manutenção de um veículo. Isso facilita que o ambiente colaborativo seja construído, não é o discurso dos associados. Por isso as pessoas vão e mandam conteúdo para a nossa página no inbox, filmam a manifestação, fotografam e pedem para postar, dizendo que é nosso, somos ninja. Acho que isso não seria possível se não tivéssemos esse modelo de organização interna.

\section{8) Como você enxerga a Mídia Ninja daqui cinco anos?}

Bem difícil essa pergunta, não consigo imaginar muito. Nós nunca trabalhamos pensando onde chegaríamos, na verdade, trabalhamos mais preocupados em como estávamos fazendo as coisas. Como fazemos as coisas, nos fez chegar a lugares completamente inimagináveis. A galera que fazia show em cidade do interior do Brasil que lançou uma banda que ganhou prêmio da Rolling Stones, com disco artista igual pedreiro é a mesma galera que lança um veículo de comunicação que vai estar na luta contra o golpe, lançando uma chapa à Presidência da República com um sem-teto e uma liderança indígena. Não é muito óbvio o percurso, brincamos que é meio Forrest Gump, o cara ganhou um campeonato mundial de pingue-pongue, criou a logo do Smiles, criou uma empresa de camarão e ficou milionário. Não tem uma linearidade. Daqui cinco anos, vamos ter a TV Ninja, um sistema de inteligência artificial que vai possibilitar o gerenciamento de super grupos de troca de informação de conteúdo com muito mais agilidade. Daqui cinco anos, teremos criado uma rede social ativista, de comunicação, cultura e colaboração global, mas, a trajetória ela não é linear, então do mesmo jeito que podemos estar aqui podemos também estar no exílio, porque a ditadura realmente aconteceu no Brasil e nos mudamos daqui e criamos uma comunidade alternativa e fomos morar em uma fazenda no Uruguai. Eu acho que assim, ainda podemos chegar em muitos lugares com a Mídia Ninja, inclusive até ao Palácio do Planalto, heim?! 